\title{
الإمام الألوسي \\ وجهوده في نقد الإسرائيليات \\ من خلال تفسيره روح المعاني
}

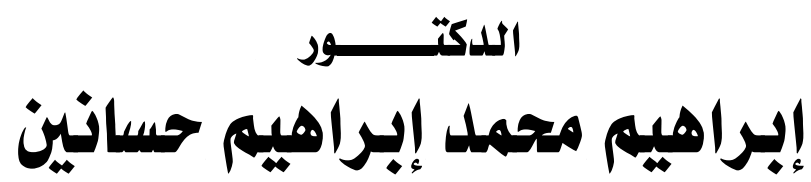

ملدرس بقسم التفسير وعلوم القرآن

كلية أصول اللدين والدعوة بالزقازيق 
$(r+r)$

الإمام الألوسي وجهوده في نقد الإسرائيليات من خلال تفسيره روح المعاني 


\section{ملخص البحث}

الحمد لله، والصلاة والسلام على سيدنا رسول الله

$$
\text { وصحبه ومن والاه، وبعد: }
$$

فإن الإسرائيليات من أنواع الدخيل التي لا يكاد يخلو منها كتاب وند

تفسير، لكن على تفاوت بين المفسرين في ذلك قلة أو كثرة، وسكوتًا

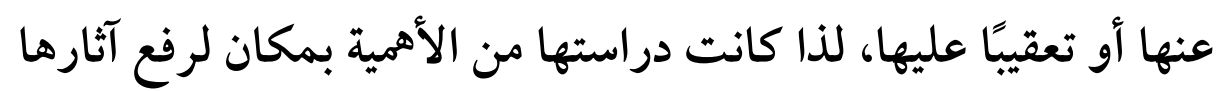

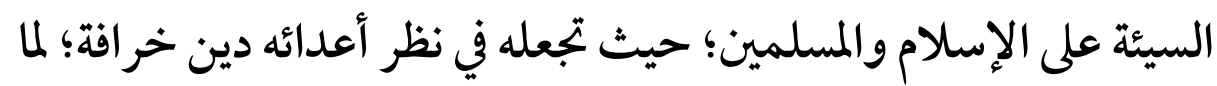
حوته من أباطيل وخرافات التخذها الطاعنون مادة خصبة للطعن في

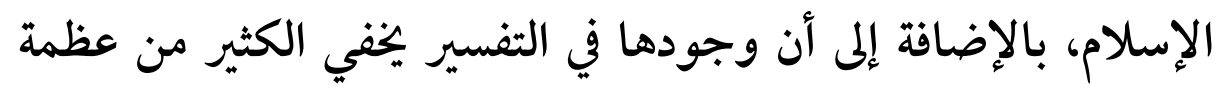
القرآن الكريم وهداياته. ويهدف البحث إلى الوقوف على موقف الإمام الألوسي من

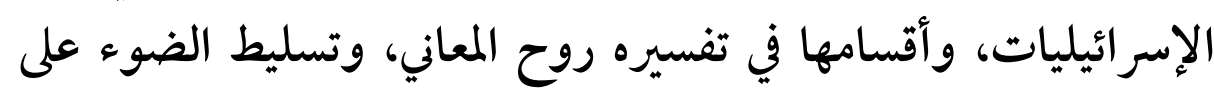

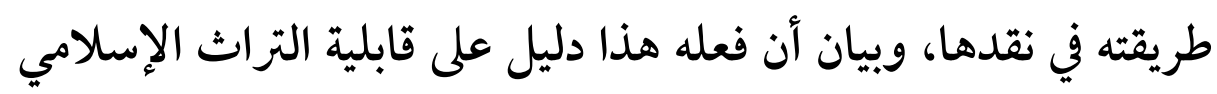
للدراسة و التحقيق و النقد. 


\section{Conclusion}

All praise is due to Allah, and may peace and blessings be upon Prophet Muhammed, his household and companions and upon everyone followed his way.

Isra'iliyyat (Narratives from the People of the Book) is a kind of insertion that mentioned in almost all books of Tafseer. The only difference is that some scholars of Tafseer added less or more than each other. Some of them commented on these Isra'iliyyat and clarified them, while others did not. So, it is so important to study and refute these matters to protect Islam and Muslims from such bad impact, as these narratives may pave the way for the enemies of Islam to label it as a religion of superstitions that includes non-authentic or fabricated stories They used such narrations as evidence for their false allegations against Islam. Moreover, inserting such Isra'iliyyat in the books of Tafseer caused a lot of ambiguity regarding the greatness and guidance of the Glorious Quran. So, this research will cover the methodology of Imam Al-Aalousy in handling these Isra'iliyyat. 


\section{بسم اللّه الرحمن الرحييم \\ مقدمة}

الحمد لله رب العالمين، والصلاة والسلام على أشرف المرسلين

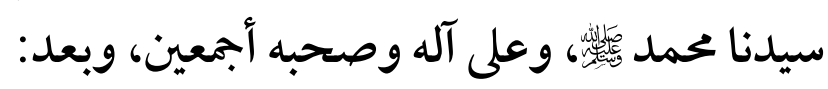

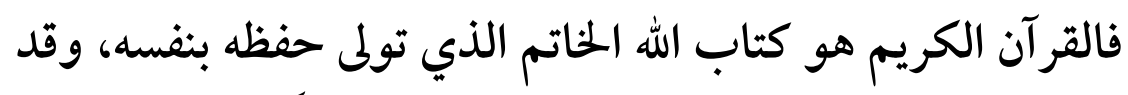

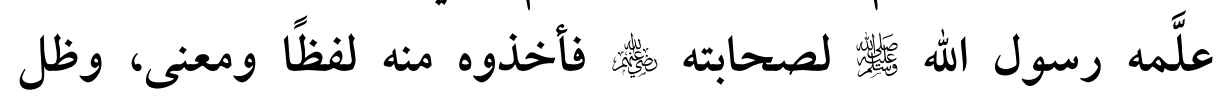

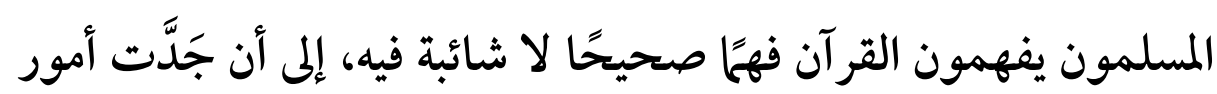

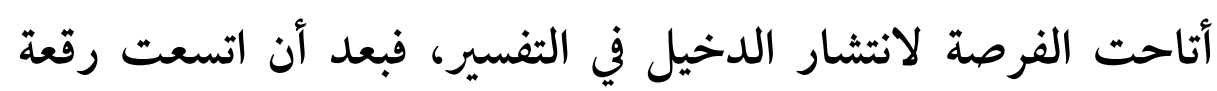
الإسلام ودخل الناس في دين الله أفواجًا، ابتليت الأمة بعدد من البلايديا،

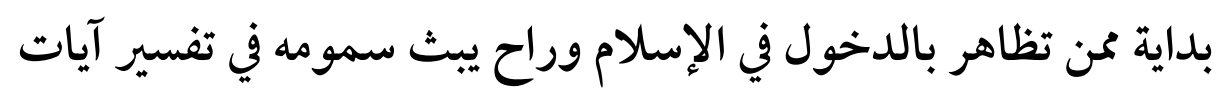

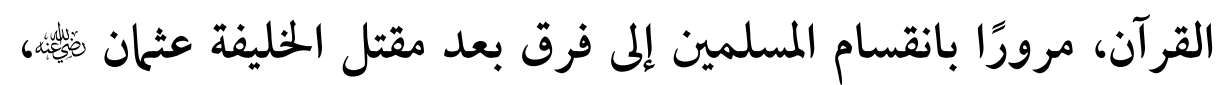

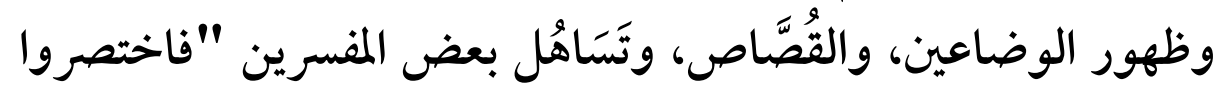

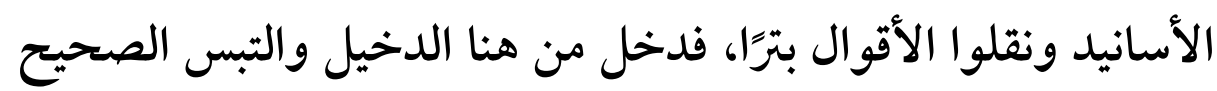

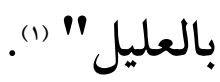
والإسرائيليات من أنواع الدخيل التي لا يكاد يخلو منها كتاب تفسير، لكن على تفاوت بين المفسرين في ذلك قلة أو كثرة، وسكوتًا عنها أو تعقيبًا عليها، لذا كانت دراستها من الأهمية بمكان لرفع آثارها (1) (الإتقان في علوم القرآن) للإمام جلال الدين السيوطي (المتوفى: (11) هــ (11)

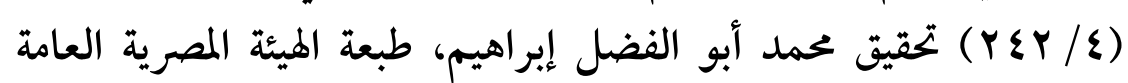

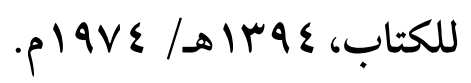


السيئة على الإسلام والمسلمين؛ حيث تجعله في نظر أعدائه دين خر افة؛ لما

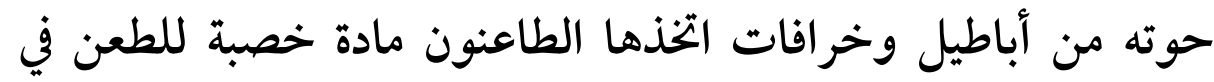

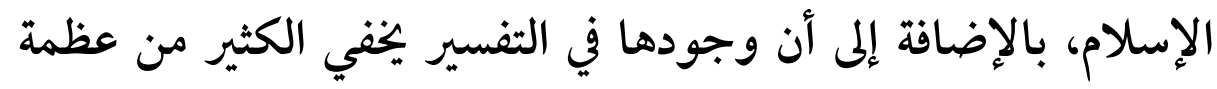

$$
\text { القرآن الكريم وهداياته. }
$$

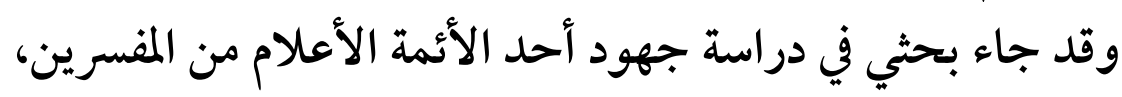

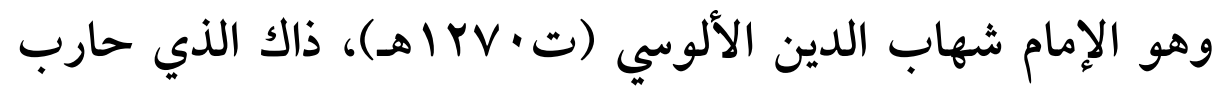

$$
\text { الإسر ائيليات، وحافظ على تنقية تفسيره إلى حد كبير منها. }
$$

\section{وجاء هذا البحث تُّت عنوان:}

"الإمام الألوسي وجهوده في نقد الإسرائيليات من خلال تونان تفسيره

$$
\text { روح المعاني" }
$$

\section{ووقع اختياري لهذا الموضوع لأهميته ولأسباب أخرى أذكرها:}

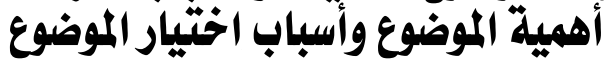

$$
\text { يرجع اختياري لهذا الموضوع إلى: الموضئ }
$$

أولاً: العناية بدراسة مناهج المفسرين واتجاهات مدرواتئ التفسير وتطوره

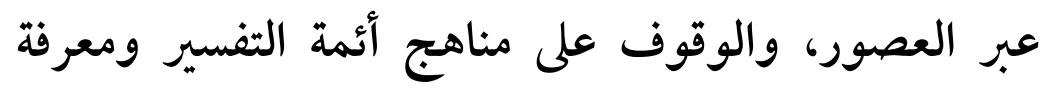

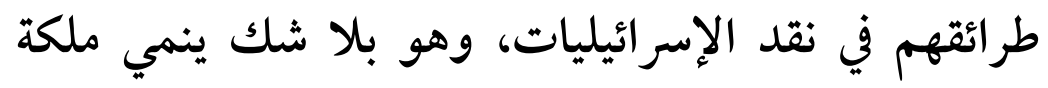

القراءة الناقدة لدى الباحث في علم التفسير.

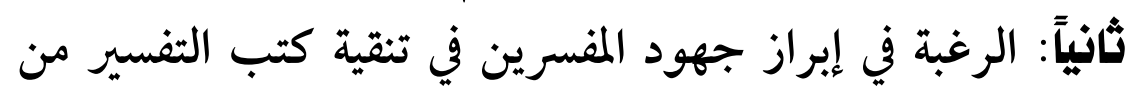


ثالثًا: القيمة العلمية لتفسير روح المعاني للإمام الألوسي، حيث

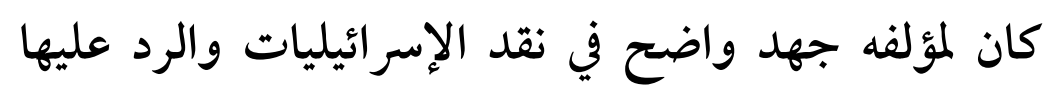
بالدليل والتعليل، وظهرت شخصيته وإنه الناقدة في عرضه الإسيات والرد عليها

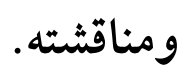

رابعاً: الرد على الطاعنين في القرآن من المستشرقين وأذنابهم بأنه

$$
\begin{aligned}
& \text { كتاب خر افة وقصص وأباطيل. } \\
& \text { أهداف البحث } \\
& \text { يهدف البحث إلى: }
\end{aligned}
$$

أولا: الوقوف على موقف الإمام الألوسي من الإسرائيليات،

$$
\text { و أقسامها في تفسيره روح المعاني. }
$$

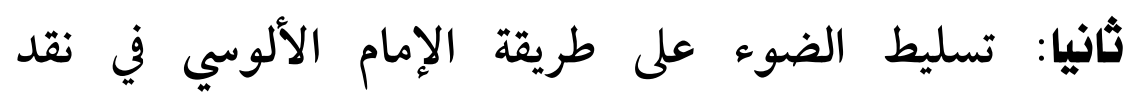

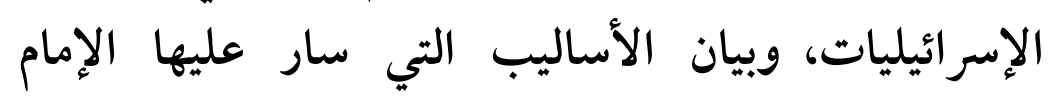

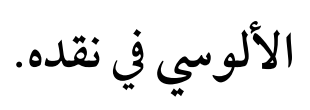

ثاثثا: بيان قابلية التراث الإسلامي للدراسة والتحقيق والنقد.

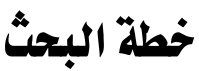

هذا؛ وقد قسمت البحث إلى مقدمة ومبحثين وخاتمة.

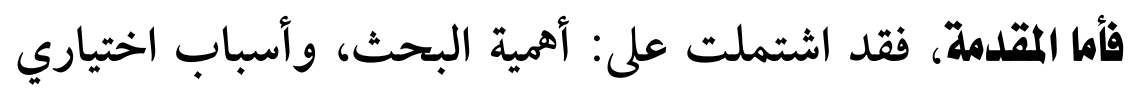

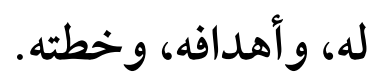




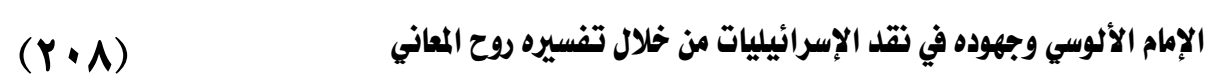

وأما المبحث الأول فمنوانه: الإمام الألوسي وتفسيره روح المعاني، وتحته مطلبان:

$$
\text { المطلب الأول: ترجمة مختصرة للإمام الألوسي. }
$$

المطلب الثاني: تعريف موجز بكتابه: روح المعاني، ومنهجه

وأما المبحث الثاني، فمنوانه: الإسرائيليات، وموقف الإمام الألوسي منها، وطريقته في نقدها. وتحته ثلاثة مطالب:

المطلب الأول: الإسرائيليات، وموقف الإمام الألوسي منها. المطلب الثاني: أقسام الإسرائيليات في تفسير الإنبام الإمام

المطلب الثالث: طريقة الإمام الألوسي في نقد الإسرائيليات.

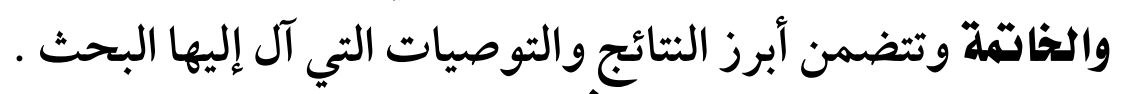

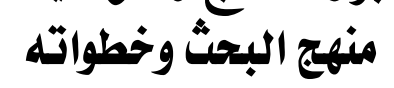

هذا؛ وقد سلكت في معالجة هذا الموضوع وكتابته "المنهج

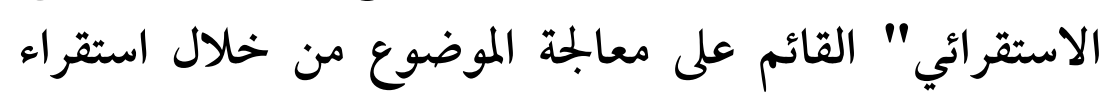

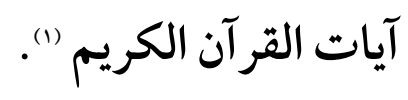

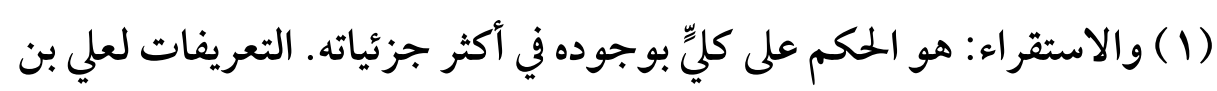

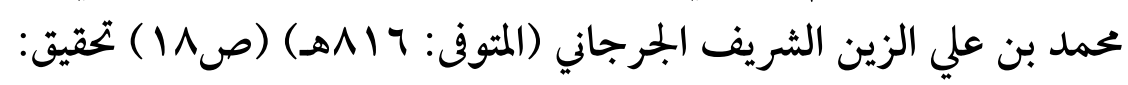

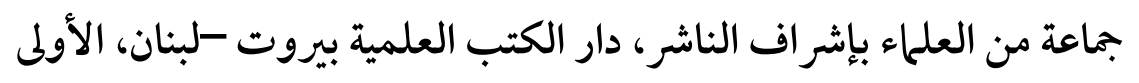

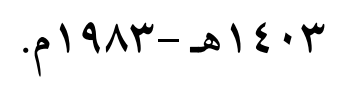




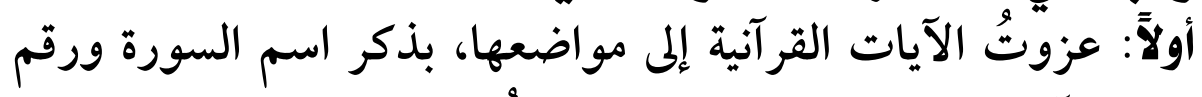

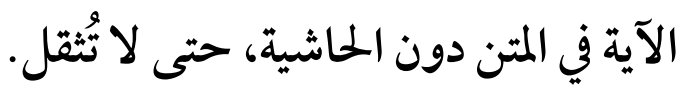

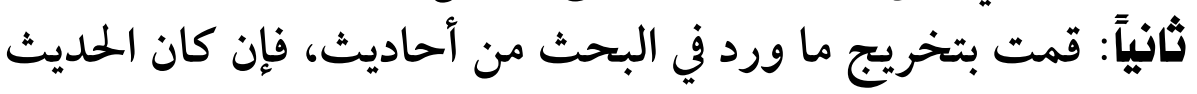

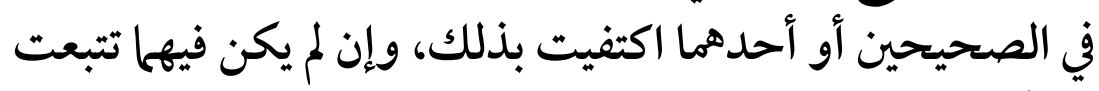

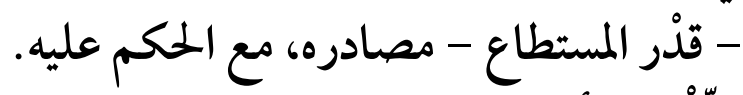

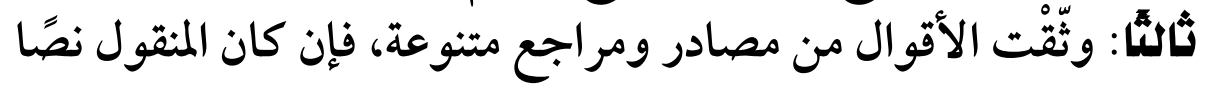

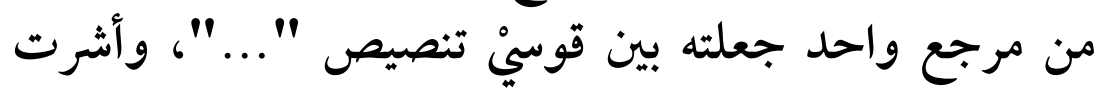

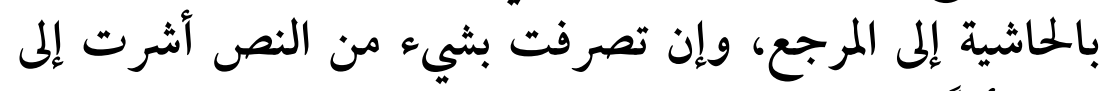

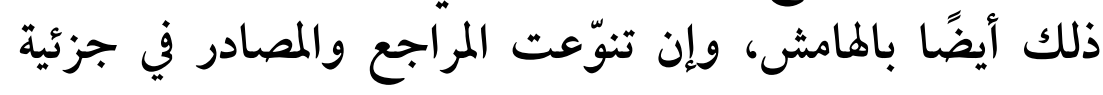

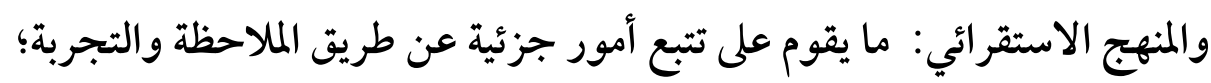

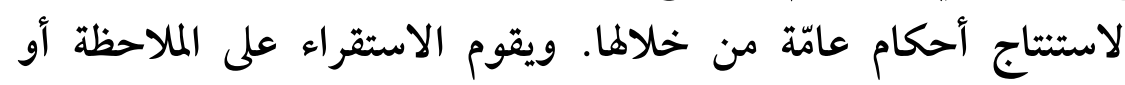
التجربة والاستطلاع والاستبانة.

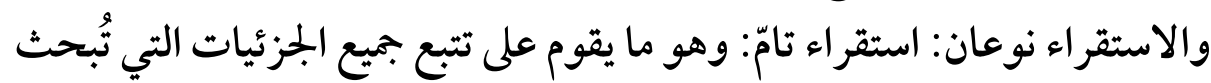

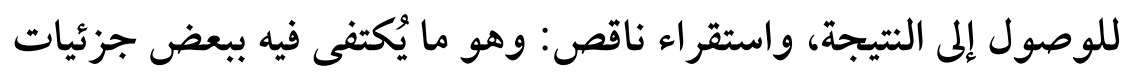

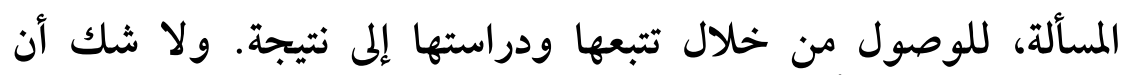

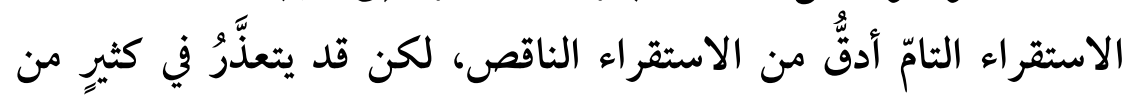

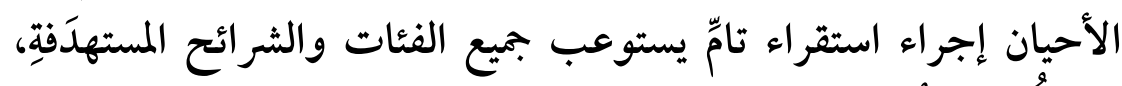

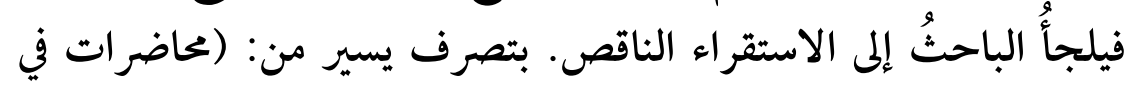

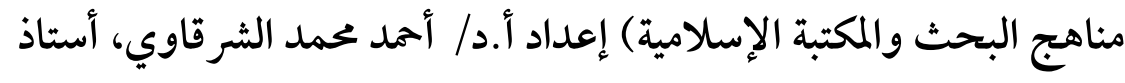

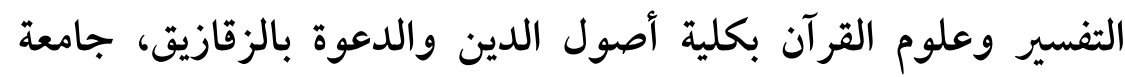

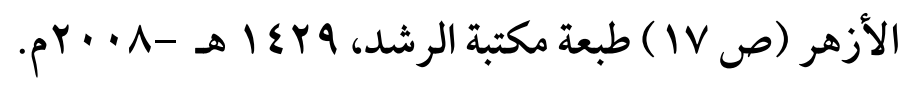


(Y) الإمام الألوسي وجهوده في نقد الإسرائيليات من خلال تفسيره روح المعاني

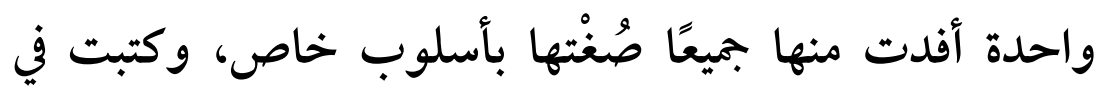

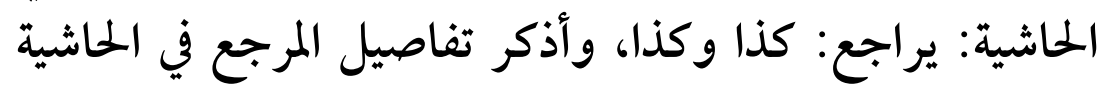

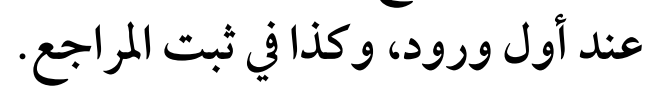

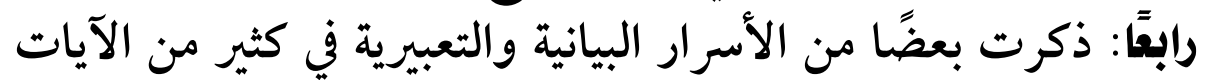

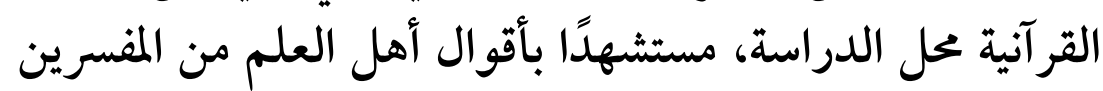

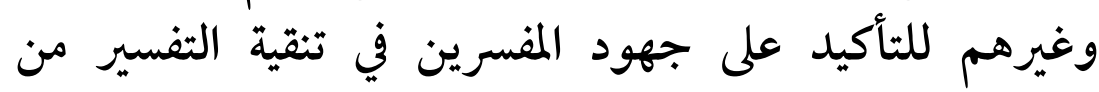

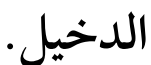
خامسًا: ترجمت للأعلام ترجمة مختصرة.

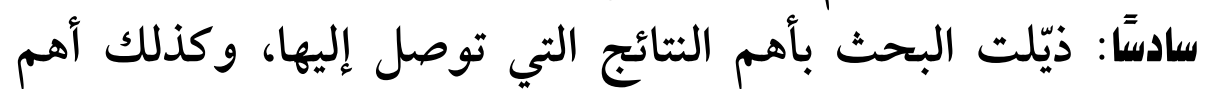

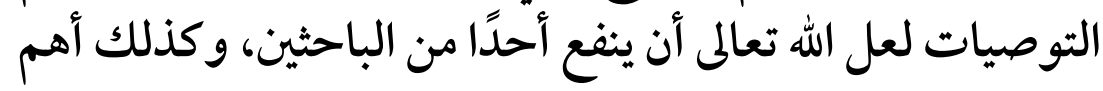

$$
\text { المصادر والمراجع. }
$$

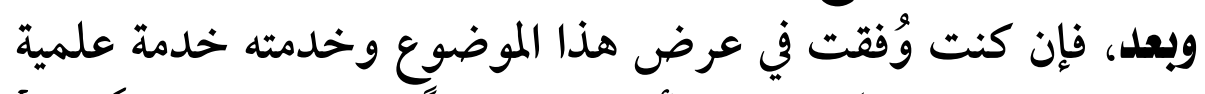

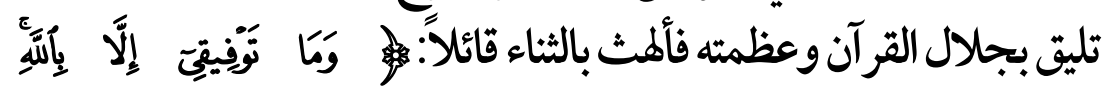

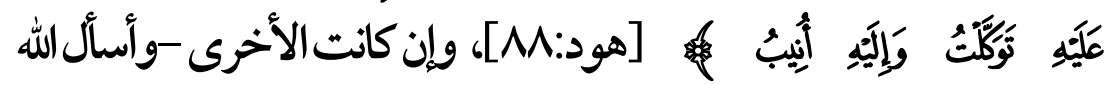

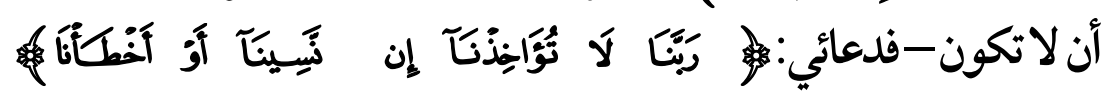

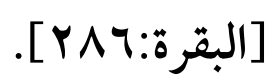

$$
\begin{aligned}
& \text { الباحث/ إبراهيم محمد إبر اهيم حسانين }
\end{aligned}
$$

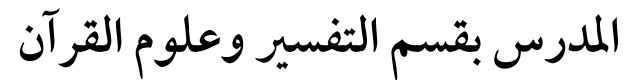

$$
\begin{aligned}
& \text { في كلية أصول الدين والدعوة بالزقازيق }
\end{aligned}
$$


(YII)

المبحث الأول: الإمام الألوسي وتفسيره روح المعاني

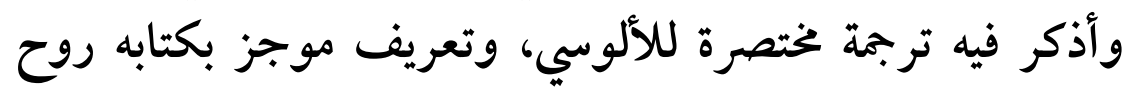

المعاني، ومنهجه الذي سار عليه فيه.

\section{المطلب الأول: ترجمة مختصرة للألوسي فيه}

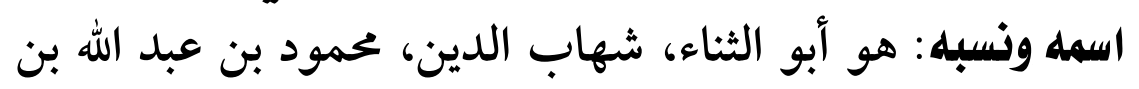
محمود بن درويش بن محمد بن ناصر الدين بن حسين الخطيب الإمام

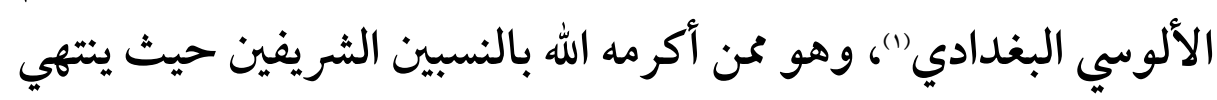

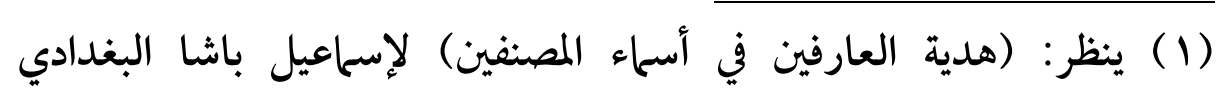

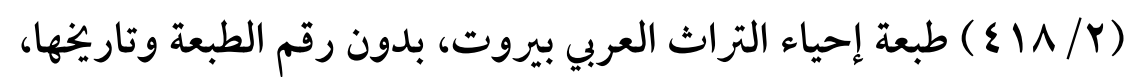

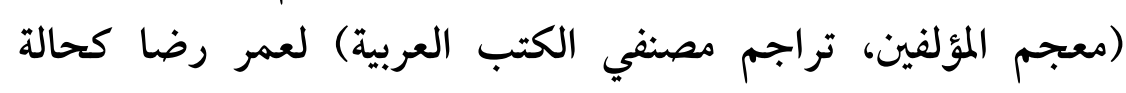

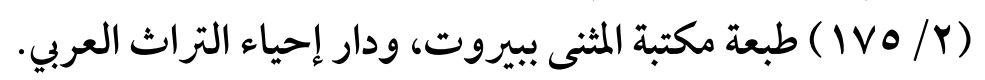

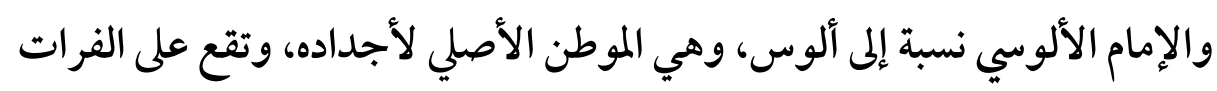

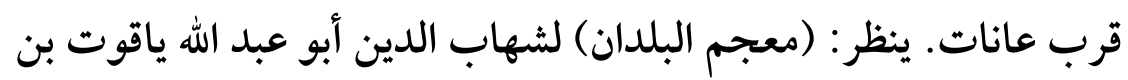

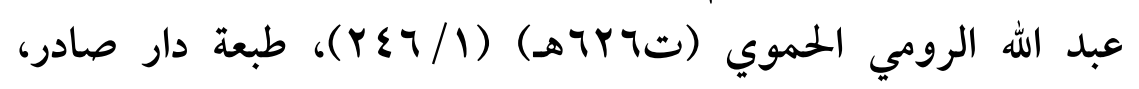

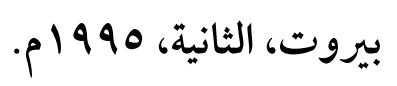
وقد دار خلاف حول قصر هذه الكلمة ومدها، فالزركلي في (الأعلام) يقول:

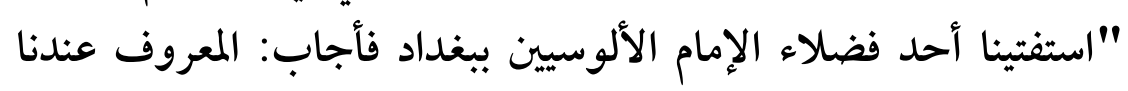

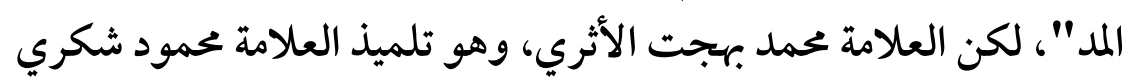

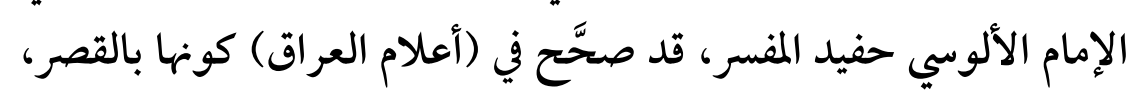

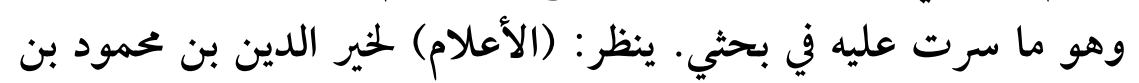

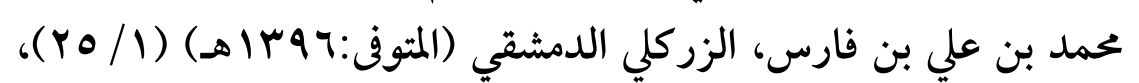


نسبه من جهة أبيه إلى سيدنا الحسين ضِئية، ومن جهة أم أبيه إلى سيدنا

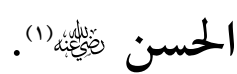

موللده: ولد يوم الجمعة، الرابع عشر من شهر شعبان، سنة سبع

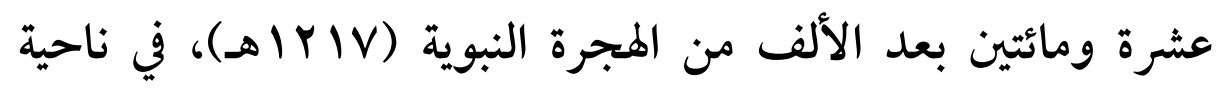

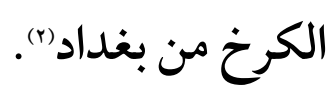

نشأته: ولد الإمام الألوسي في أحضان أسرة علمية فوجد العناية

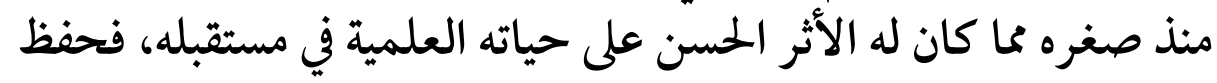

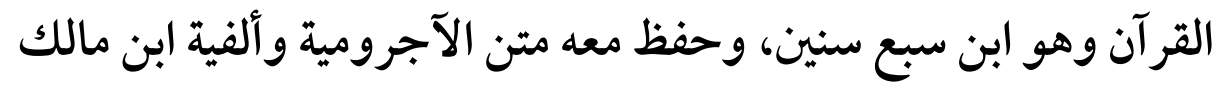

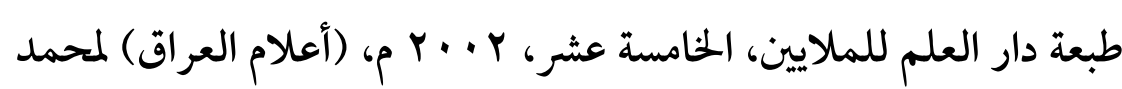

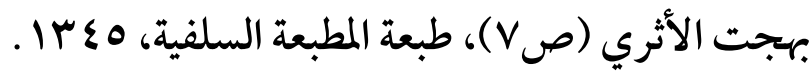

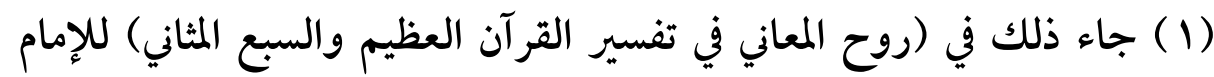

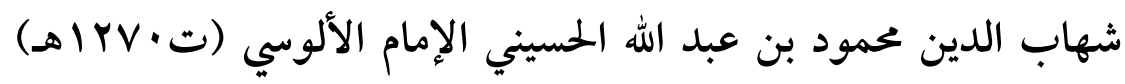

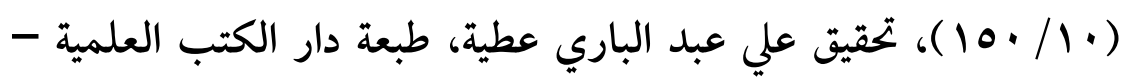

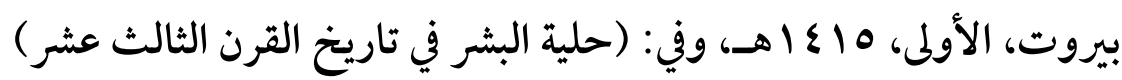

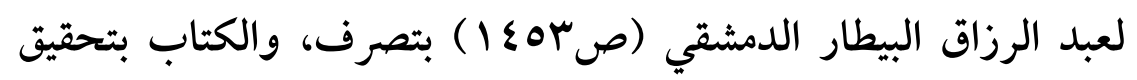

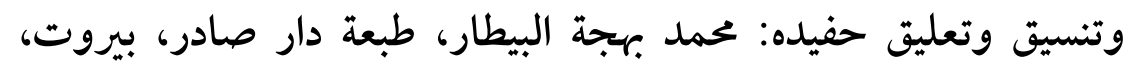

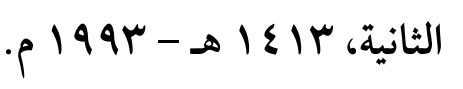

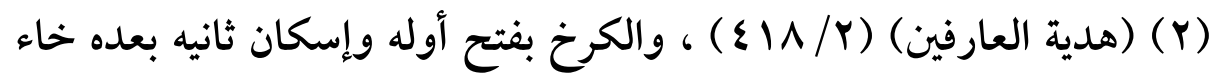

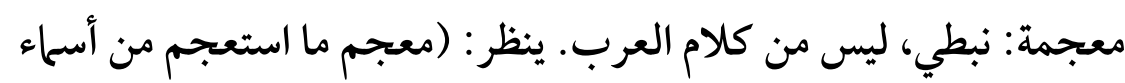

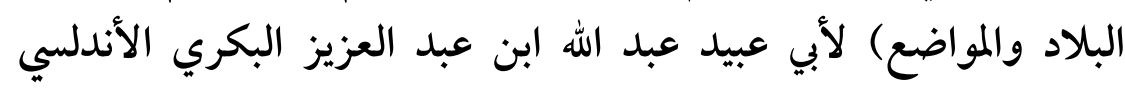

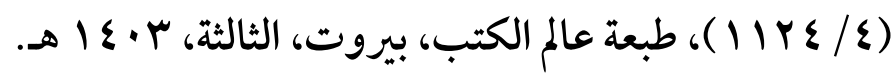


والمنظومة الرحبية في الفرائض، وقبل العاشرة كان قد درس علوم

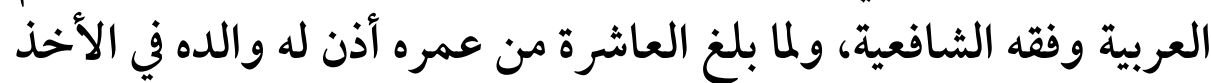

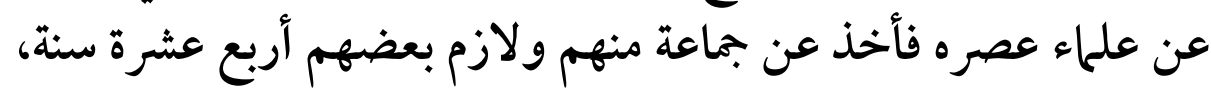

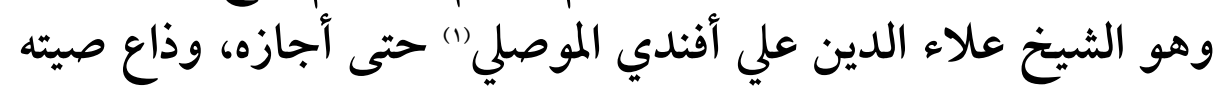

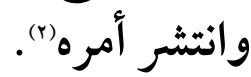

مكاتته: كان الإمام الألوسي شيخ العلماء في العراق، وآية من آيات

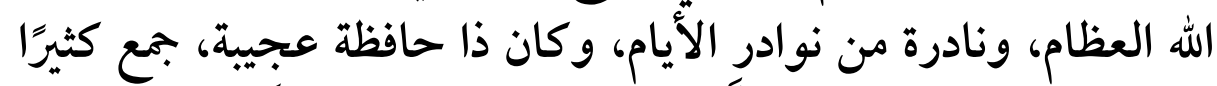

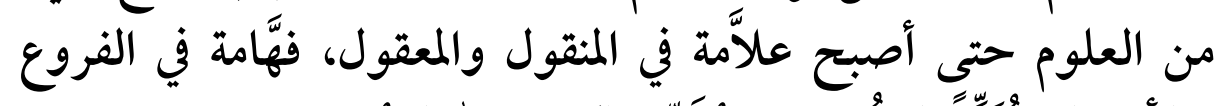

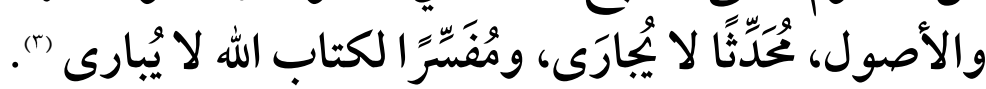

(1) هو علاء الدين علي بن يوسف الموصلي، لازمه الشيخ الألوسي أربع عشرة إنهاء

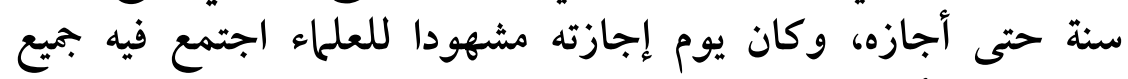

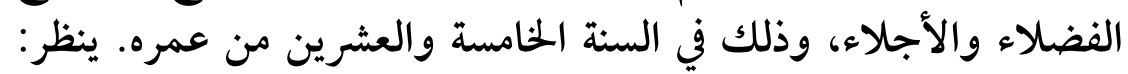

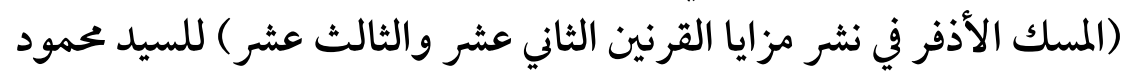

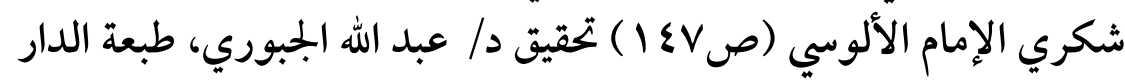

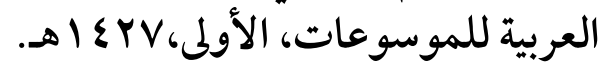

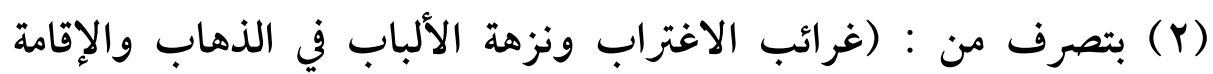

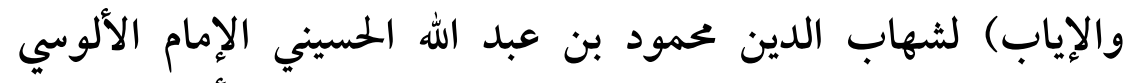

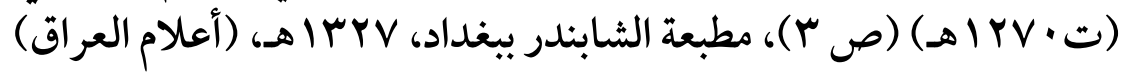
(صYY)

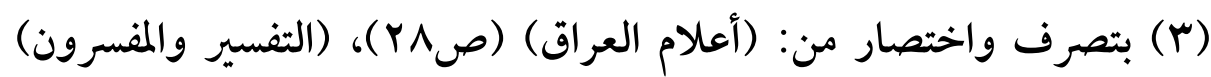

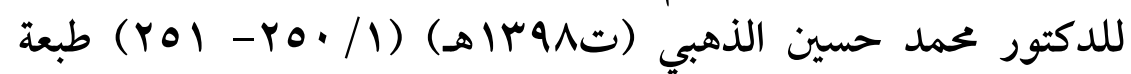
مكتبة وهبة، القاهرة. 
وكان مقصد علماء الآفاق في المسائل المعضلات ، ومحط أنظار

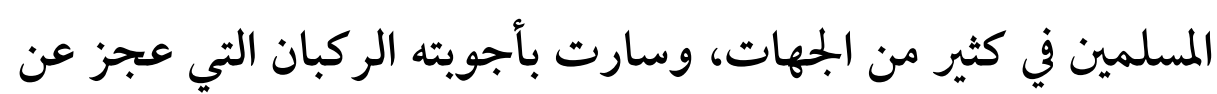

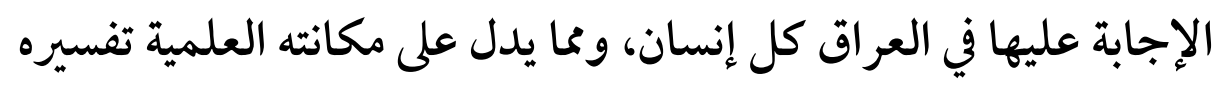

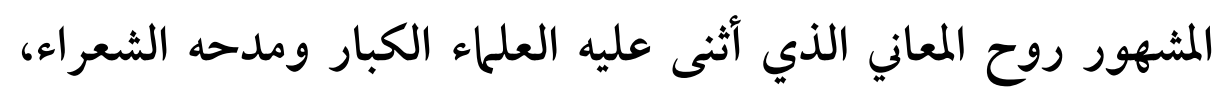

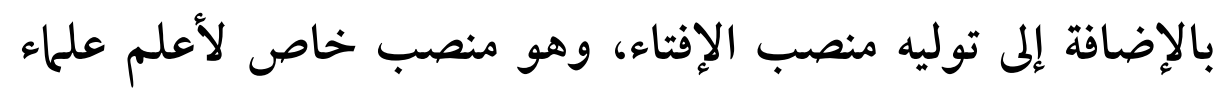

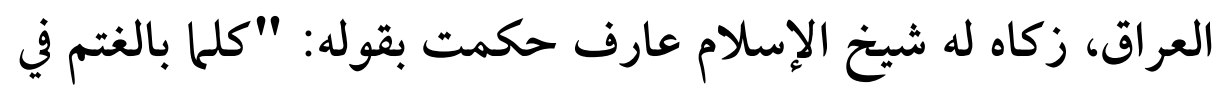

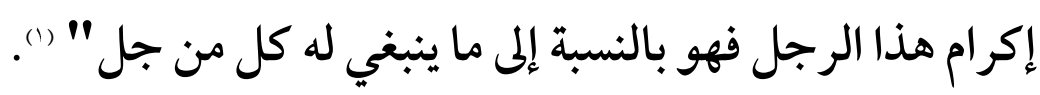

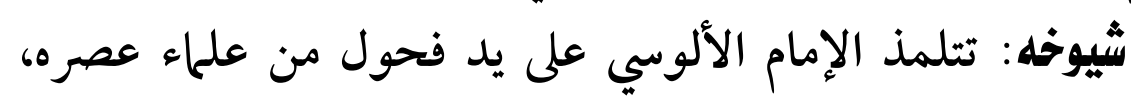

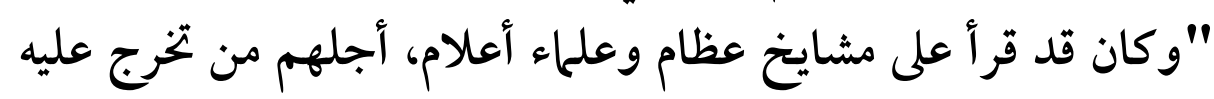

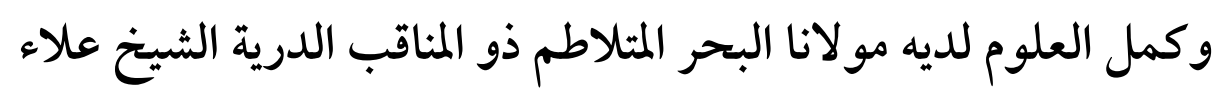
الدين علي أفندي الموصلي، مدرس الحضرة القادرية" (ه) ومنهم:

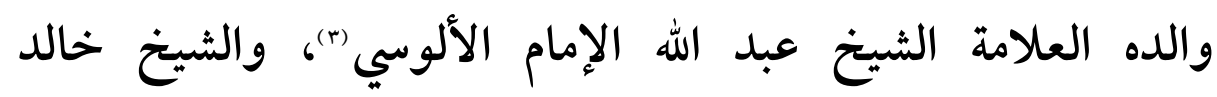

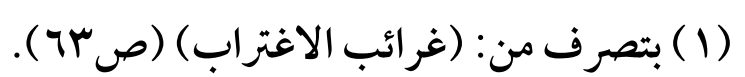

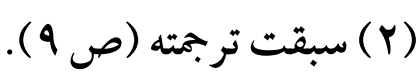

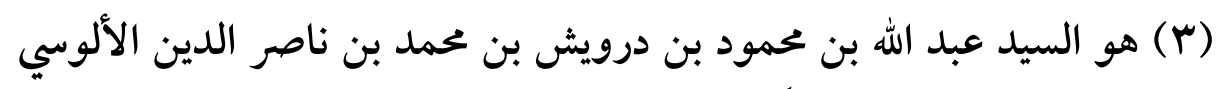

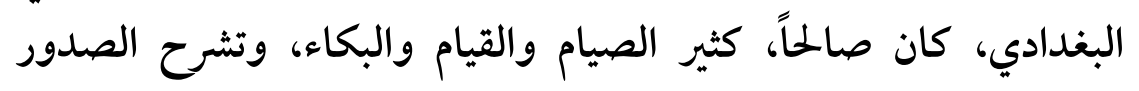

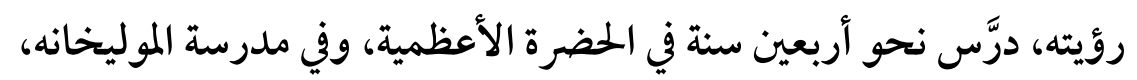

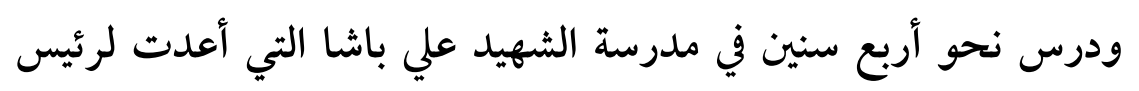

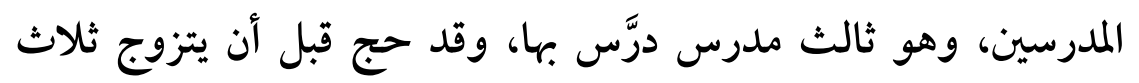


(Y)O)

النقشبندي"(1)، والشيخ على السويدي"()، وغيرهم كثير، وقد اقتصرت على ذكر أشهرهم اختصارا.

عقيدته: الإمام الألوسي أشعري العقيدة، يقول عنه حفيده أبو

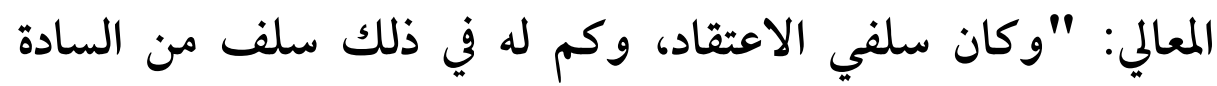

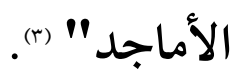

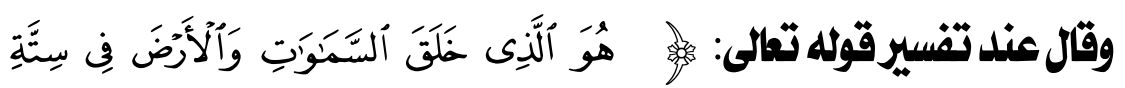

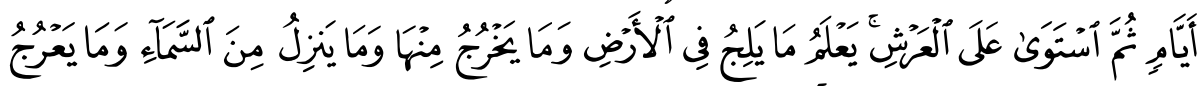

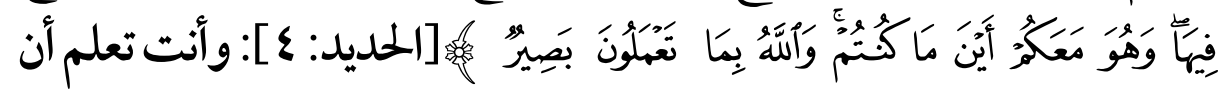

مرات. ترجمثه في: (غرائب الاغتراب) (صاY)، (أعلام العراق)

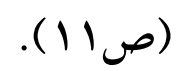

(1) هو أبو البهاء، خالد بن أحمد بن حسين، ضياء الدين النقشبندي، شيخ

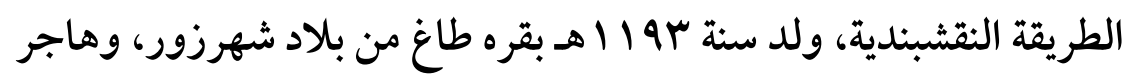

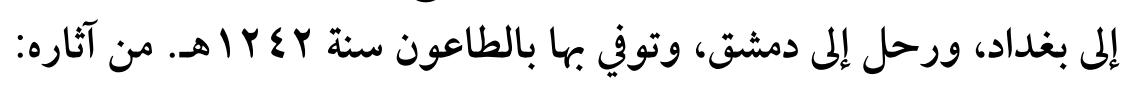

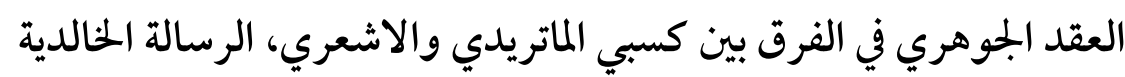

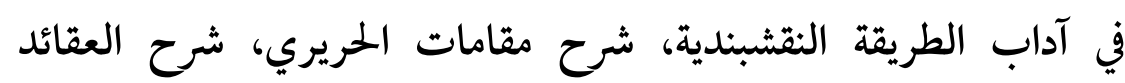

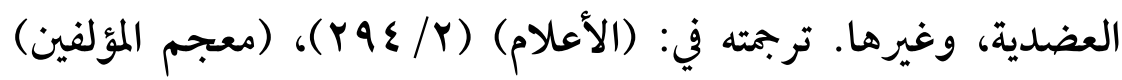

(Y) هو علي بن عبد الله البغدادي، السويدي، متكلم، من آثاره: المثكاة المضيئة في

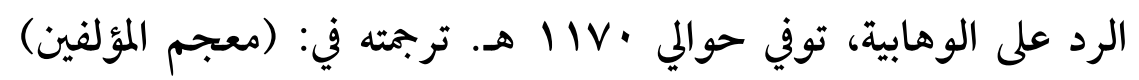
(Irr/V)

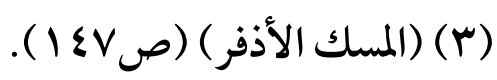


الأسلم ترك التأويل فإنه قول على الله تعالى من غير علم ولا نؤوّل إلا ما

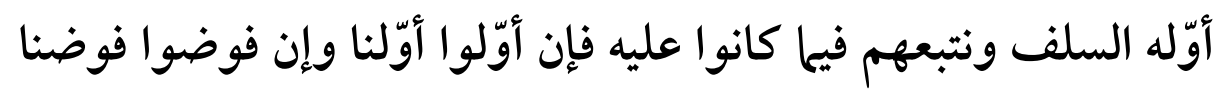
ولا نأخذ تأويلهم لشيء سلم) لتأويل غيره (1).

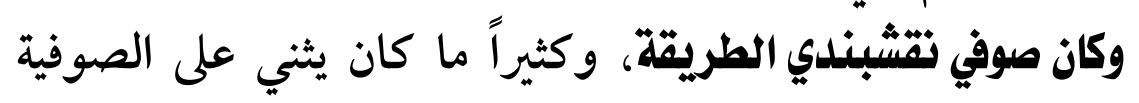

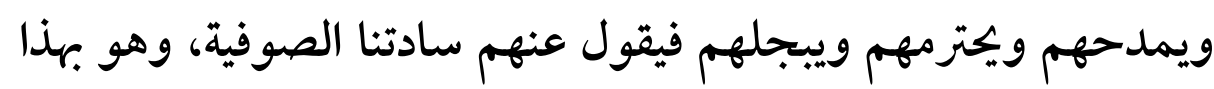

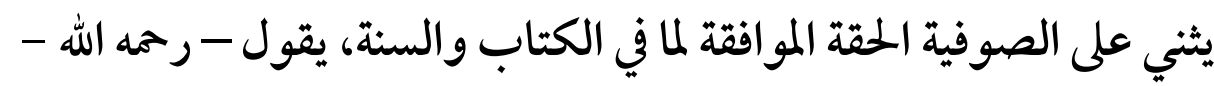
عنهم: "فلما كانت طرائق سادتنا الصوفية، أحيى الله تعالى قلوبنا بأنفاس همهم الذكية الزكية من أرجى أسباب الوصول إلى حضرة

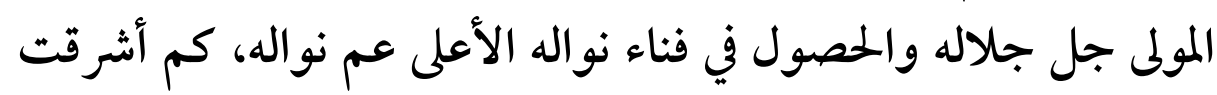
من بروجها شموس العرفان، وحصل بالسلوك فيها الفناء والبقاء الاتمان، وقد اتضحت منها المسالك فلا يضل فيها بتوفيت الله تعالى

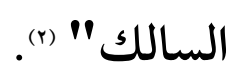

ومن جهة أخرى فإننا نجده ينكر أشد النكير على من يتمسحون بالتصوف، وهو من أفعالهم براء، فيبين عوارهم - فمثلاً - عند تفسيره

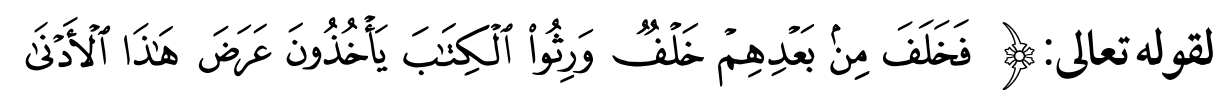

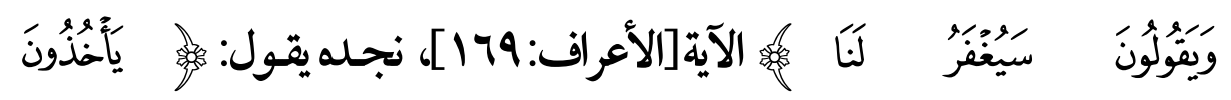

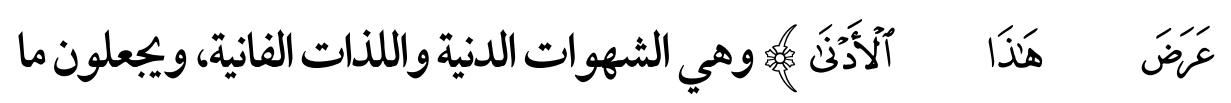

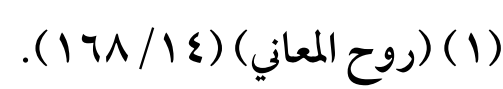

$$
\begin{aligned}
& \text { (Y) (غرائب الاغتراب) (ص · ع ا ) ). }
\end{aligned}
$$




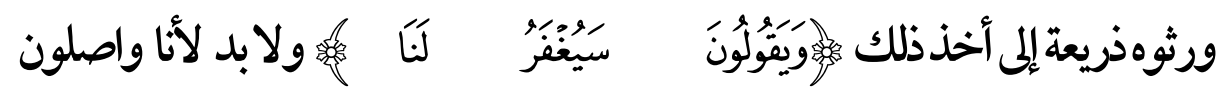
كاملون، وهذا حال كثير من متصوفة زماننا فانهم يتهافتون على

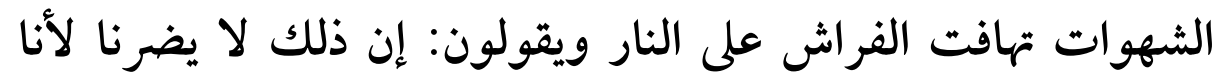
واصلون.

مذهبه الفقهي: كانت أسرة الإمام الألوسي شافعية المذهب، وبدأ

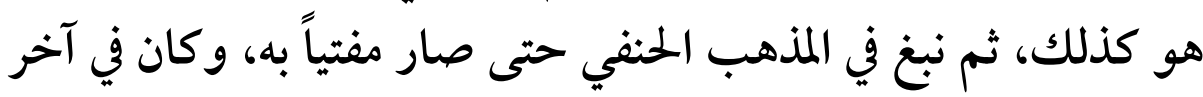

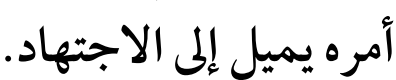

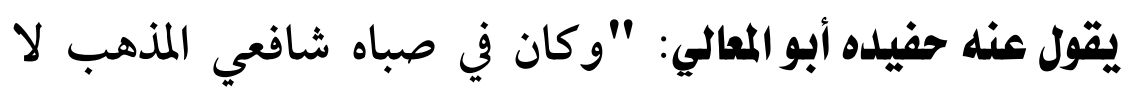
يميل لسواه ولا يذهب، وقلد مدة إفتائه الإمام أبا حنيفة في معاملاته، وبقي على ما كان عليه في عباداته، و كان بعد عزله يقول: أنا شافعي ما لم يظهر لي دليل، وإلا فليس عن العمل من محيل، حيث إن العال العالم إذا علم الدليل لا يعذر بالاعتقاد، وليس عن العمل باجتهاده من محيد" "(1).

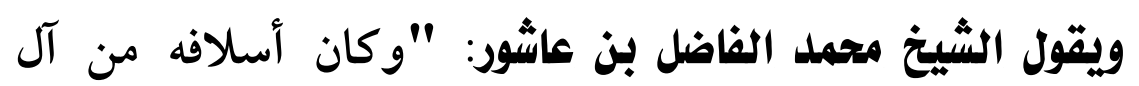
الألوسي شافعية المذهب فتفقه في مذهب أسلافه، ونزع في كثير من

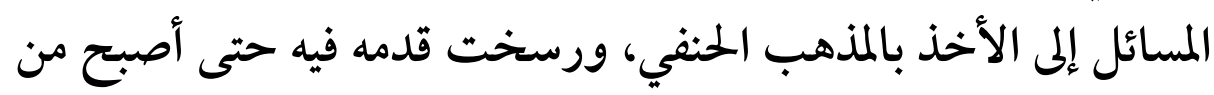

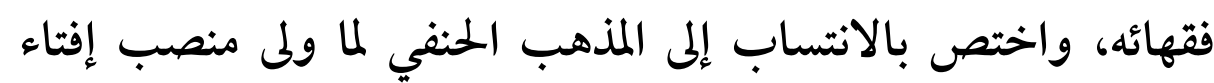


الحنفية ببغداد، وإن كانت نزعته الحقيقية نزعة استقلالية اجتهادية يجنح

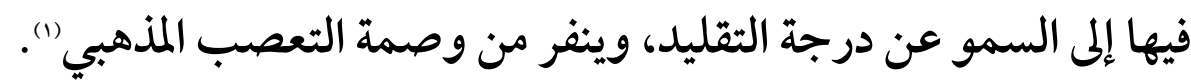

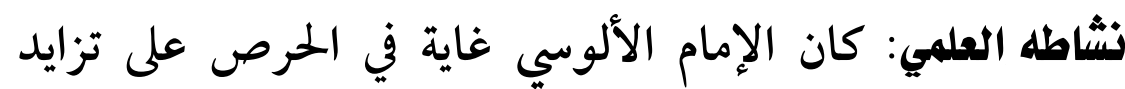
علمه، وتوفير نصيبه منه، ولقد ظهر نبوغه العلمي في حسن الجمع بين

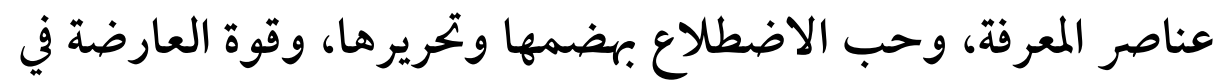

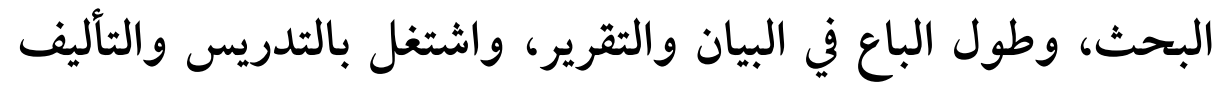

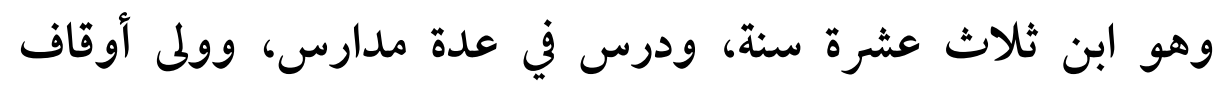
المدرسة المرجانية، وتعلم فقه الحنفية في فترة وجيزة حيث وديث إن الإنتاء

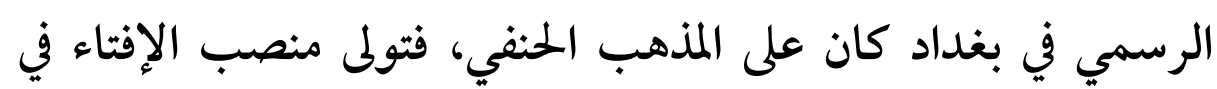

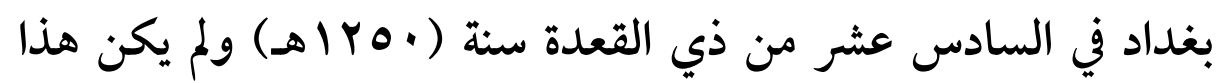
المنصب يعطى إلا لأعلم أهل البلاد، وشرع يُدَرِّس سائر العلوم في داره

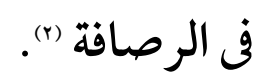

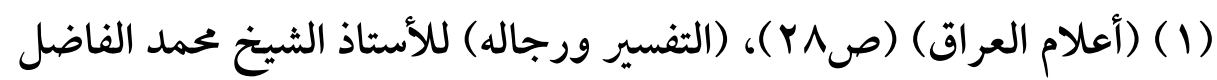

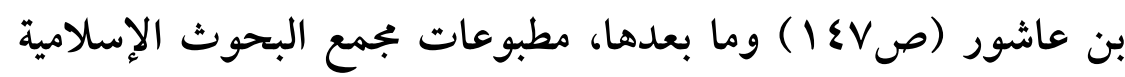

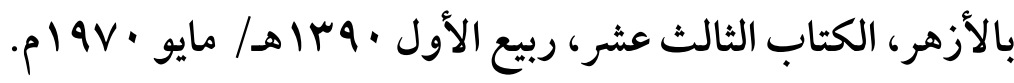

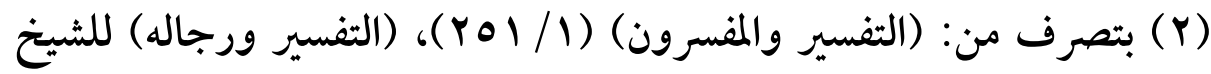

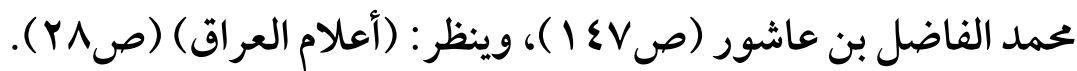
والرصافة منطقة تقع على الجانب الشرقي لنهر دجلة، وهى الآن أحد قسمي مدينة

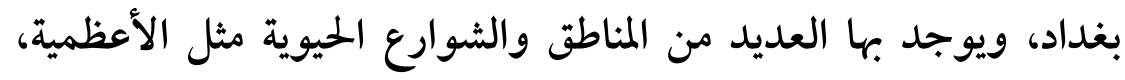


مؤلثاته: صنف الإمام الألوسي في فنون متنوعة ومعارف متعددة،

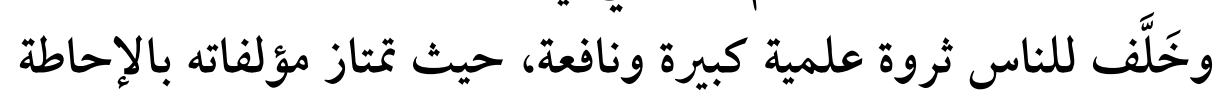
والعمق واستقلال الفكر وحريته مع روعة البيان وحسن الافتنان في صياغة المعاني والأفكار، وقد جاوزت مؤلفاته عشرون مؤلفا أعظمها بخلاف الفتاوى والمراسلات والأشعار.

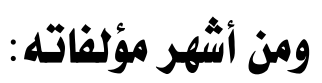

1 - تفسيره: روح المعاني في تفسير القرآن آلعظيم و السبع المثاني (1)

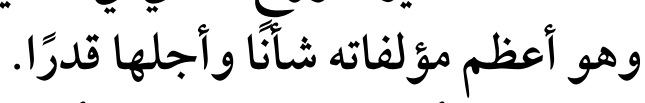

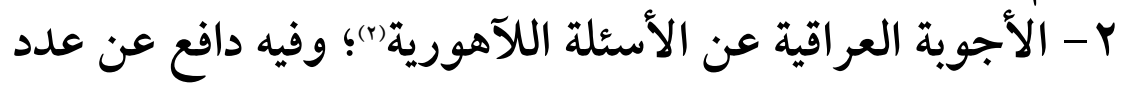

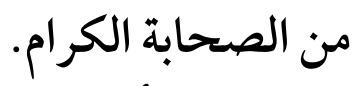

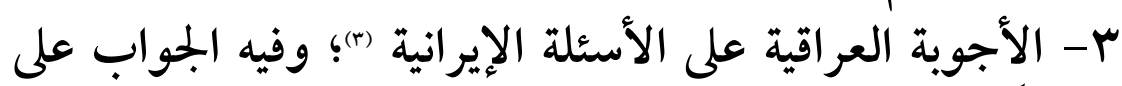

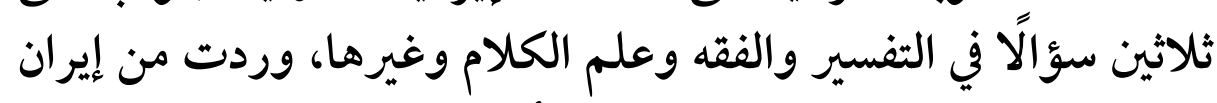

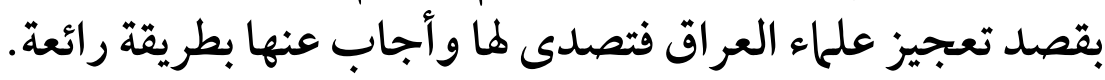

وشارع فلسطين، وشارع أبي نواس. ينظر: /https://ar.wikipedia.org

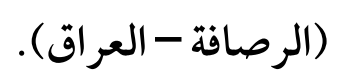

(اعبع عدة طبعات، ومنها: طبعة دار الكتب العلمية - بيروت، وهى التي

$$
\text { اعتمدت عليها. }
$$

(Y) طبع عدة طبعات، منها: طبعة دار ابن القيم للنشر والتوزيع بالرياض، ودار

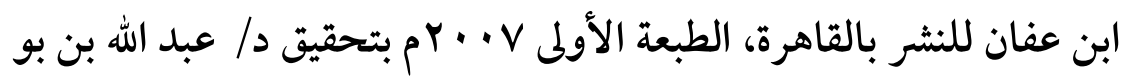

$$
\text { شعيب البخاري. }
$$

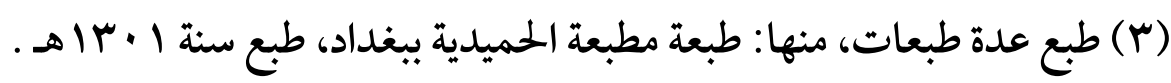


ع - النفحات القدسية في المباحث الإمامية")؛ وفيه دافع عن مذهب

$$
\text { أهل السنة والجماعة بأسلوب بارع. }
$$

0- غرائب الاغتراب ونزهة الألباب في الذهاب والاب والإقامة

والإياب(r) ترجم فيه لنفسه وبعض مشايخه والعلماء الذين لقيهم في طريقه أو في إسلام بول وبعض الأبحاث العلمية والأدبية التي جرت

$$
\text { بينه وبين الشيخ عارف حكمت في إسلام بول. }
$$

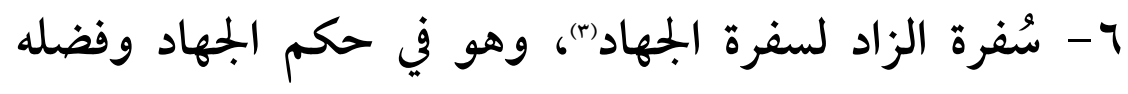

$$
\text { وحكم مصالحة المحاربين. }
$$

تلاميذه: نهل من بحر علم الإمام الألوسي الكثير من الفضلاء،

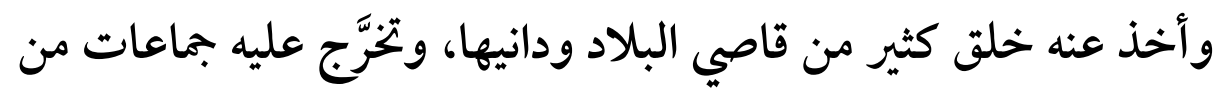

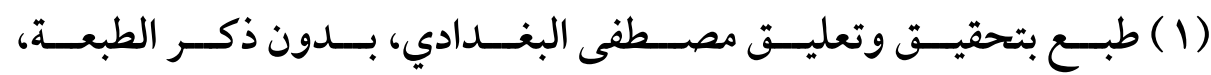

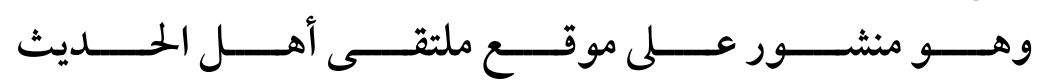
http://www.ahlalhdeeth.com/vb/showthread.php?t=r

$$
\wedge \vee \leqslant \leqslant 1
$$

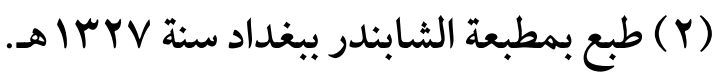

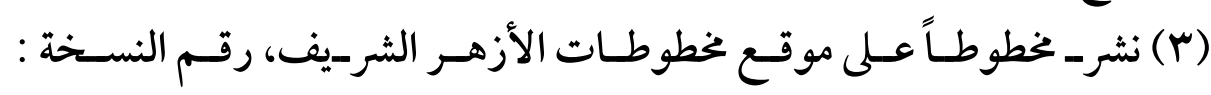

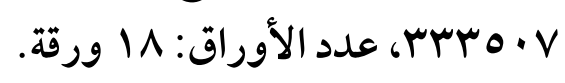

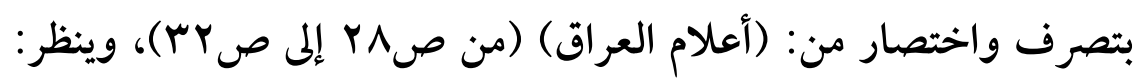

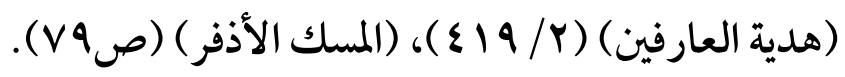


الفضلاء من بلاد مختلفة كثيرة، منهم: أخواه عبد الرحمن (1)،

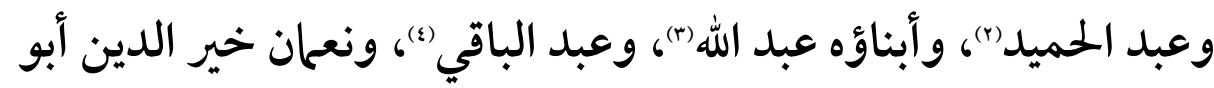

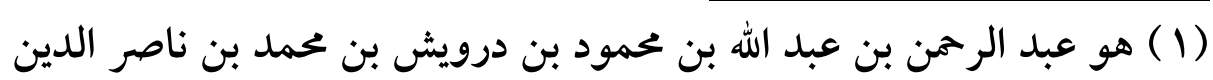

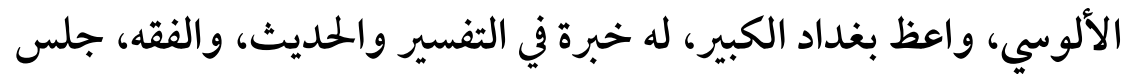

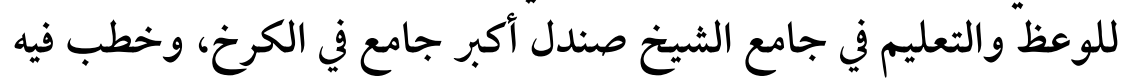

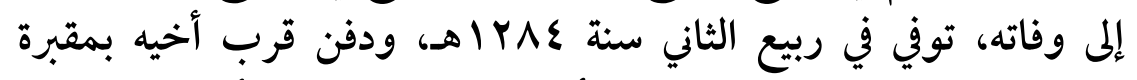

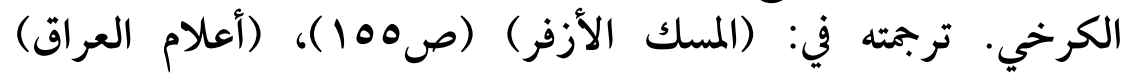

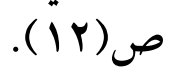

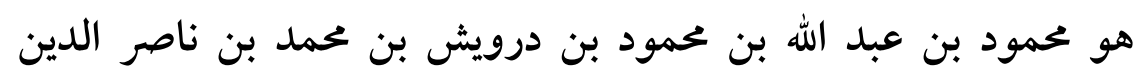

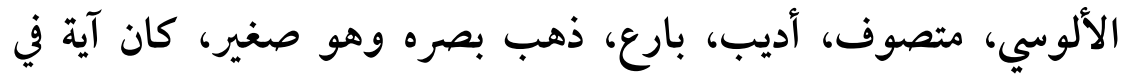

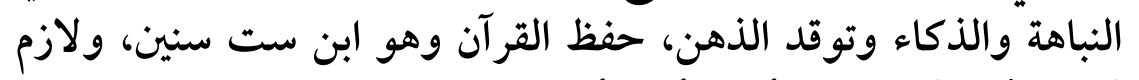

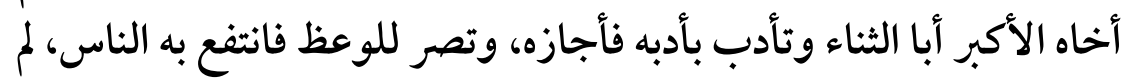

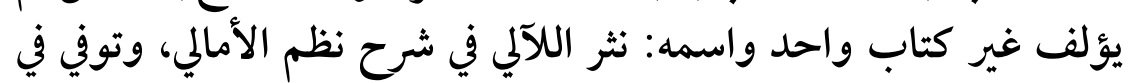

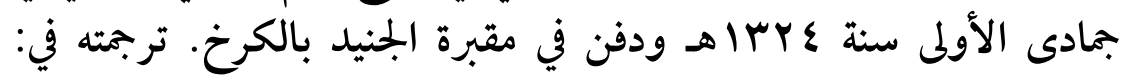

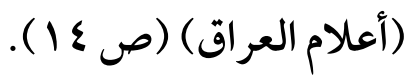

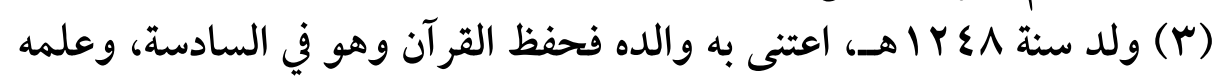

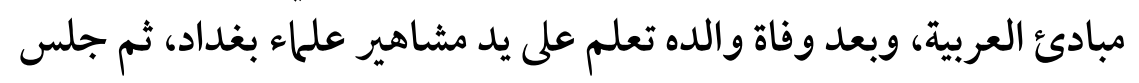

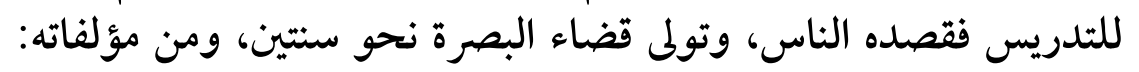

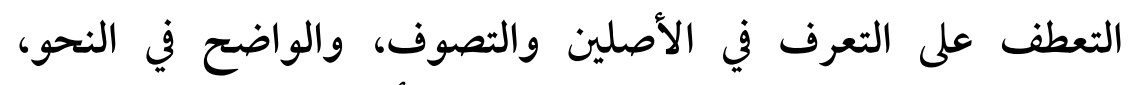

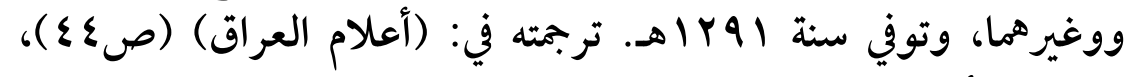

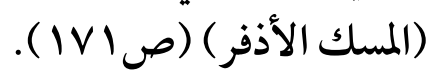

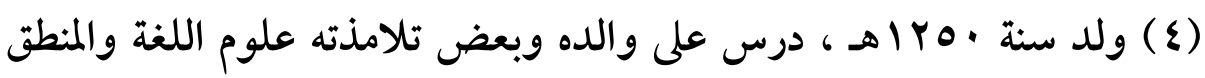

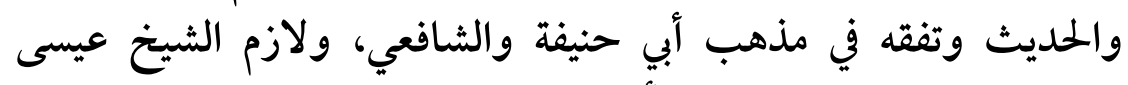

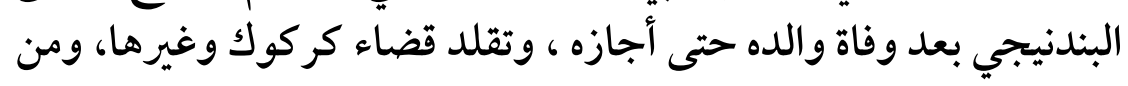


البركات"()، وعبد الفتاح أفندي الشواف(()، ومحمد أمين أفندي

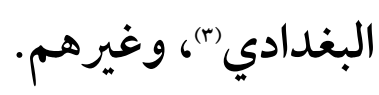

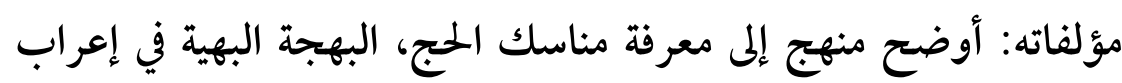

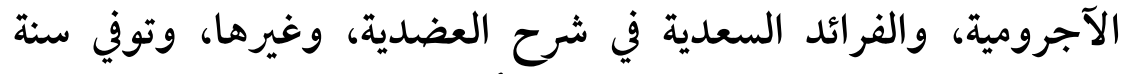

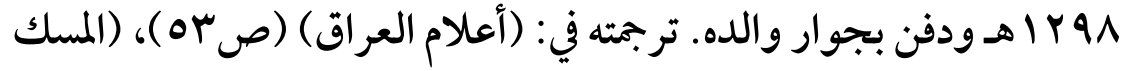

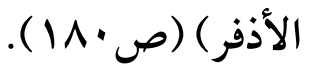

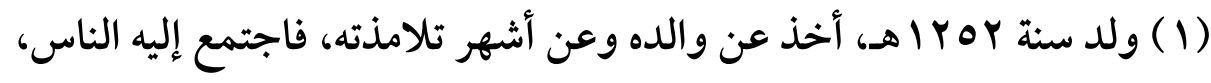

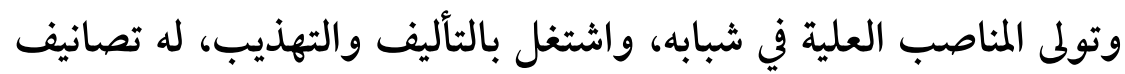

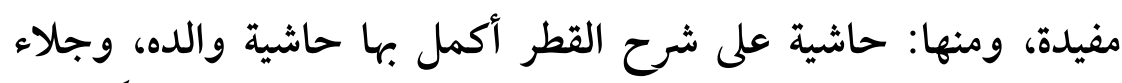

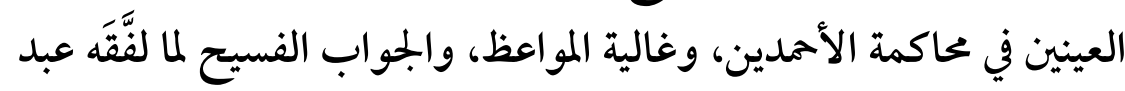

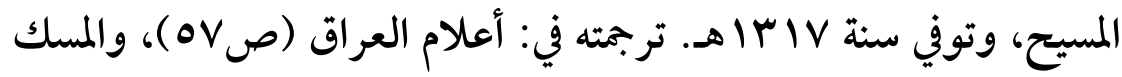

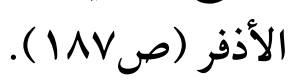

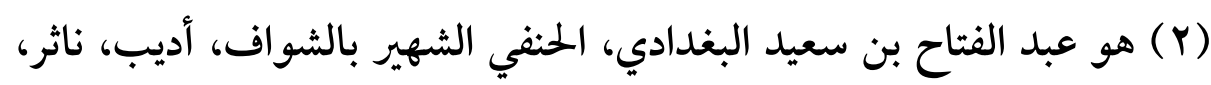

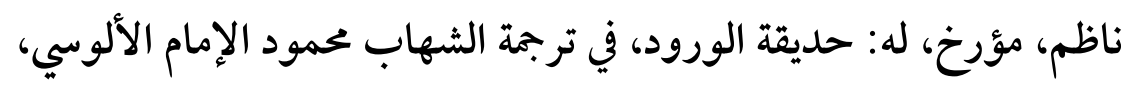

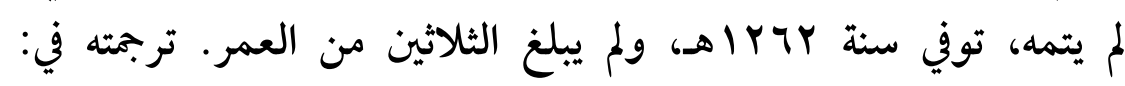

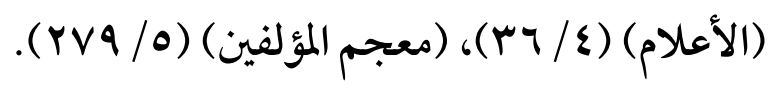

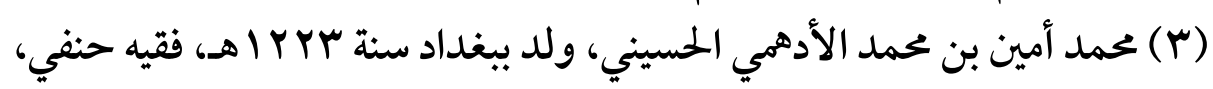

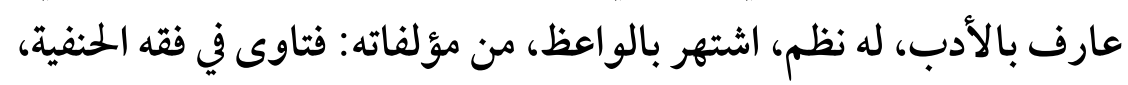

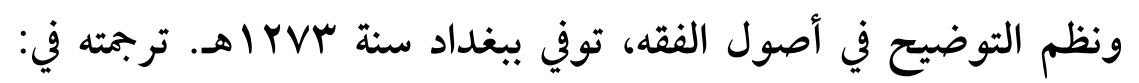

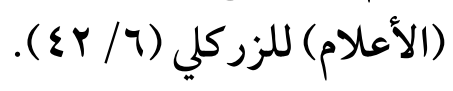


(rrY)

وفاته: توفى الإمام الألوسي في يوم الجمعة الخامس والعشرين من

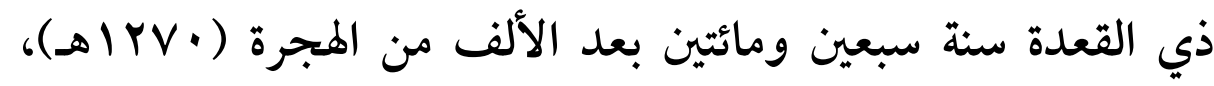

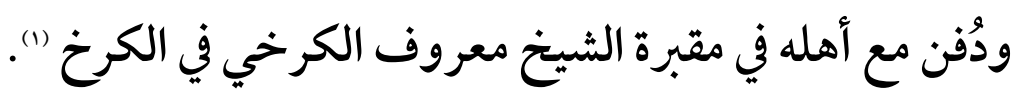

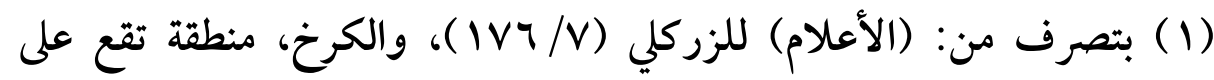

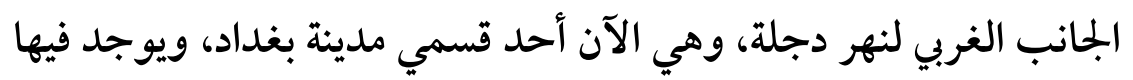

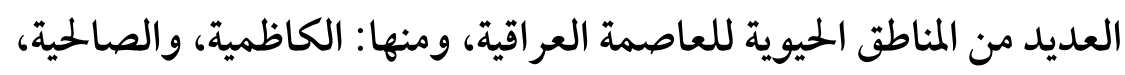

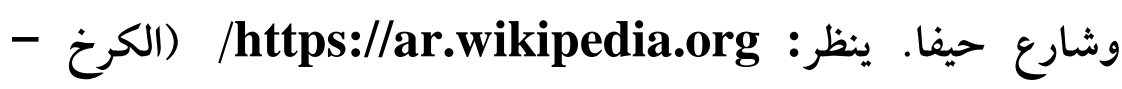

العراق). - منارع 
(Yr\&)

\section{المطلب الثاني: تعريف موجز بكتابه: روح المعاني ومنهجه فيه}

يعتبر تفسير روح المعاني موسوعة علمية جمع فيه الإمام الألوسي المياني

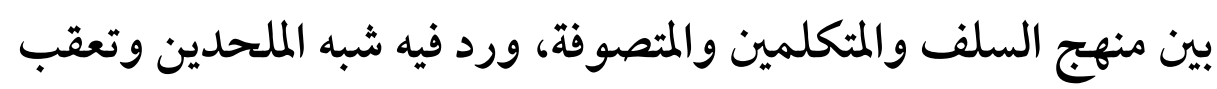

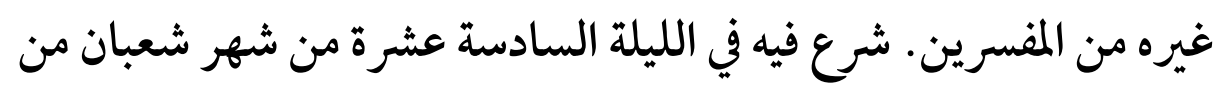

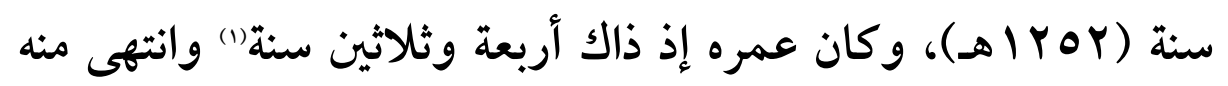

(1 ) ولتأليفه لهذا التفسير قصة عجيبة، يقول فيها: "رأيت في بعض ليالي الجمعة

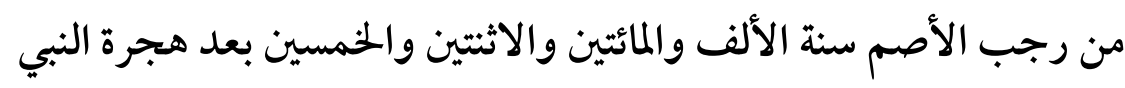

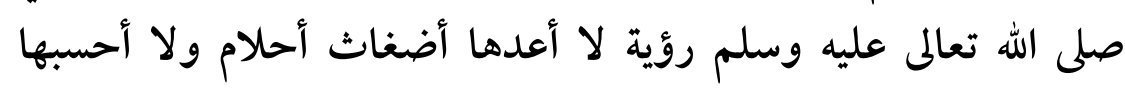

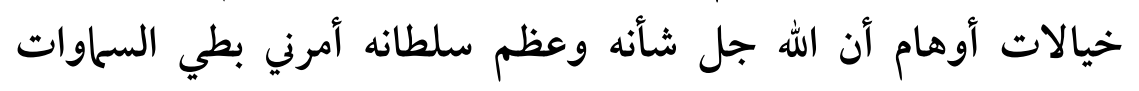

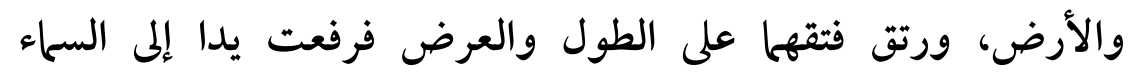

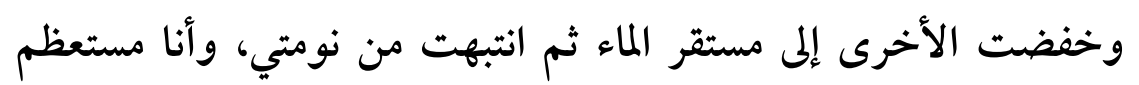

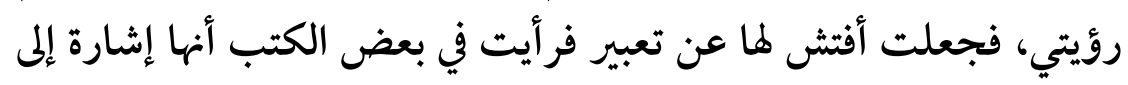

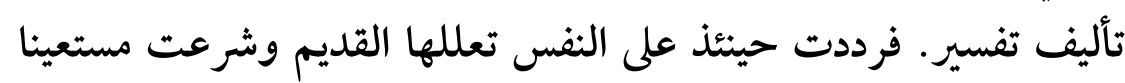

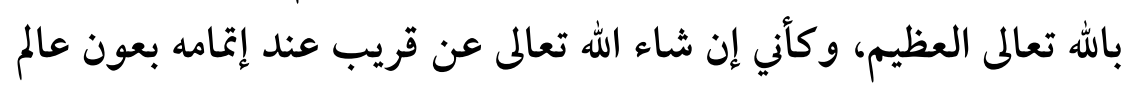

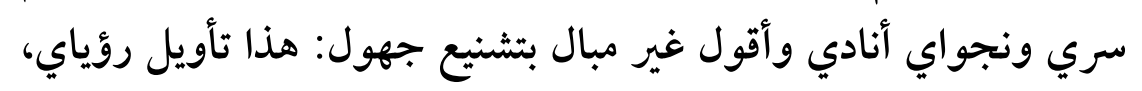

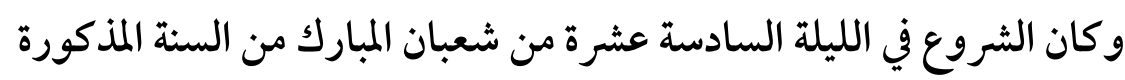

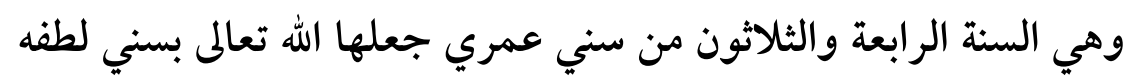

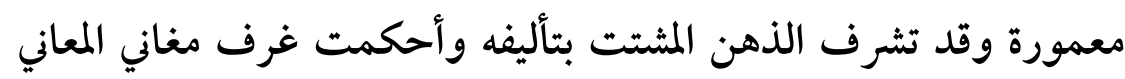

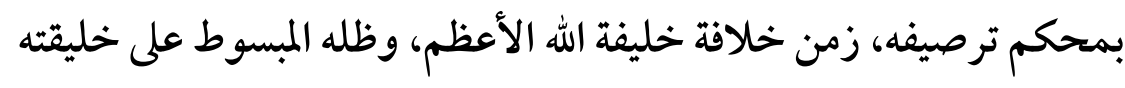

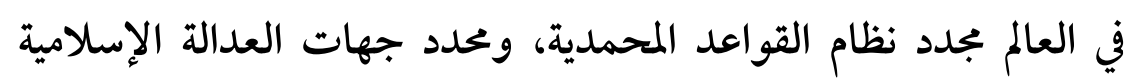
سورة الحمد الذي أظهره الرحمن في صورة الملك لكسر سورة الكافرين، 
ليلة الثلاثاء لأربع خلون من شهر ربيع الآخر (سنة VI Y ا هـ)(1)، وبهذا

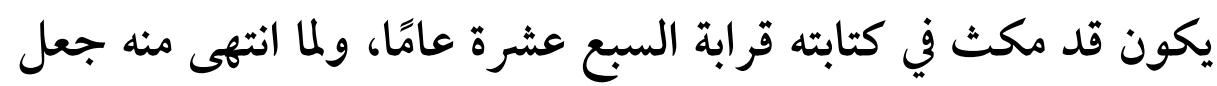
يفكر في اسم له، فعرض الأمر على وزير الوزراء علي رضا باشا، فسماه على الفور: "روح المعاني في تفسير القر آن العظيم والسبع المثاني" ل().

وآية السيف الذي عوده الفاطر والفتح والنصر وأيده بمرسلات الذاريات

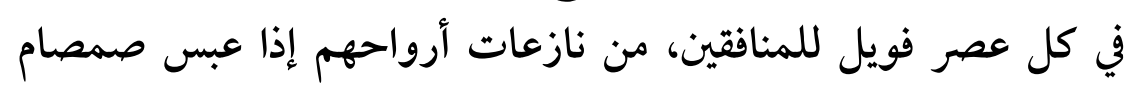

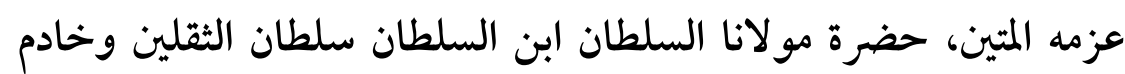

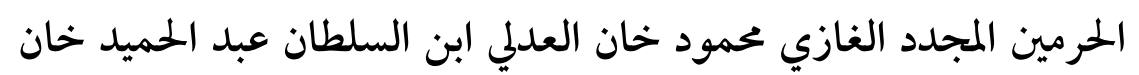

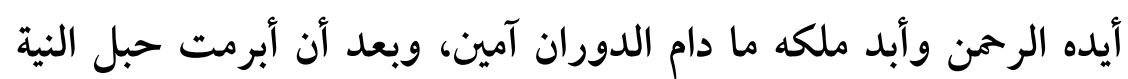

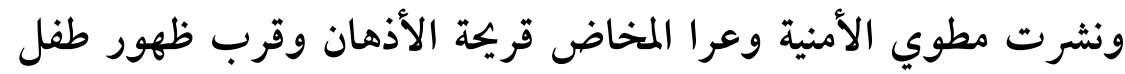

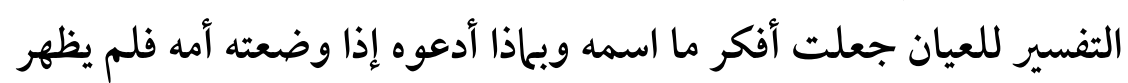

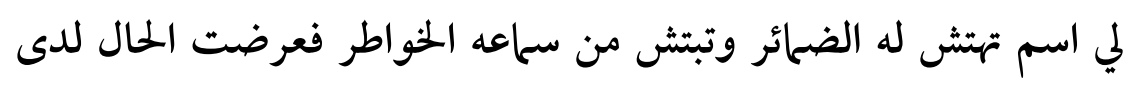

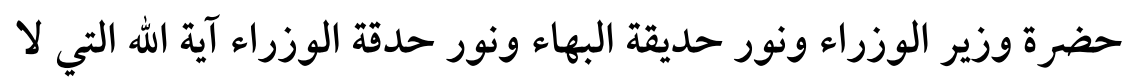

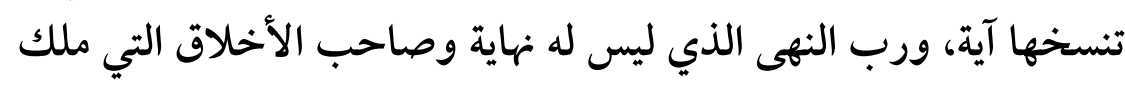

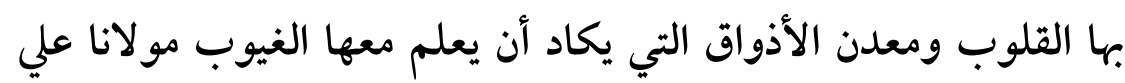

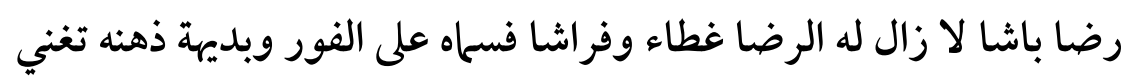

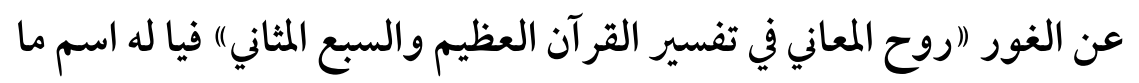

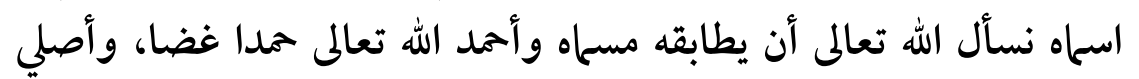

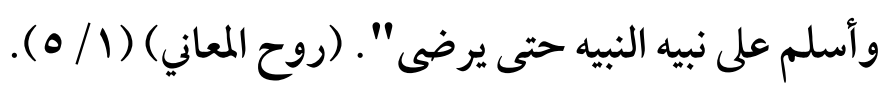

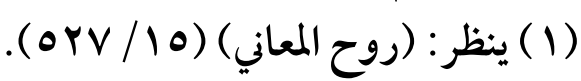

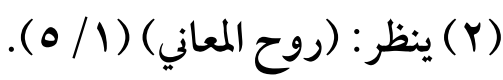




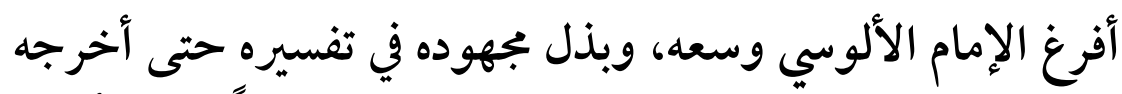

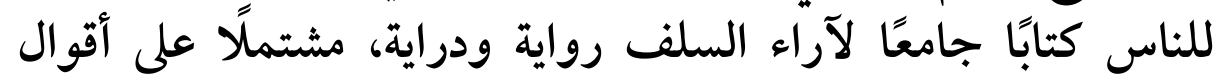

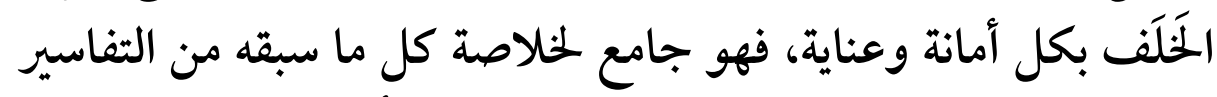

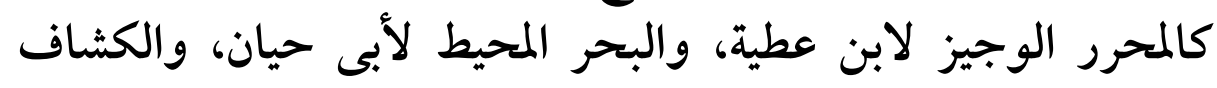

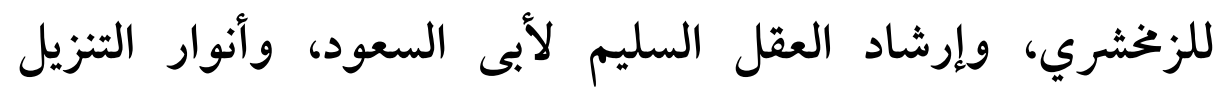

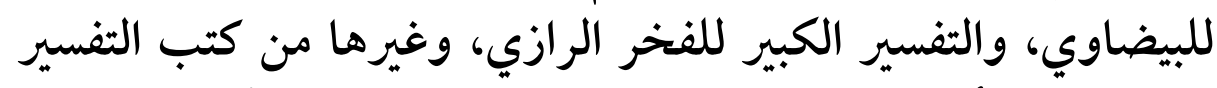

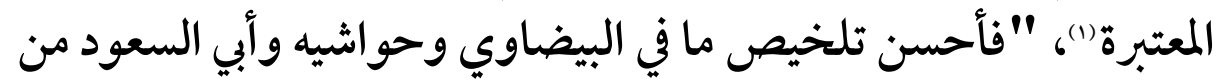

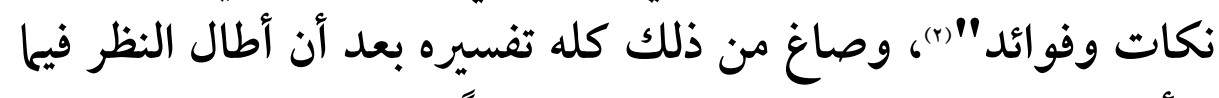

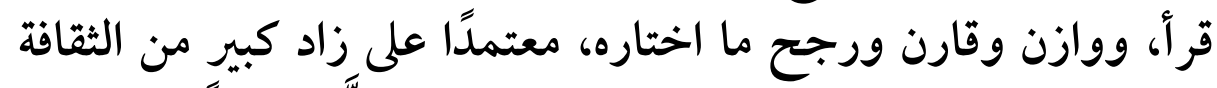

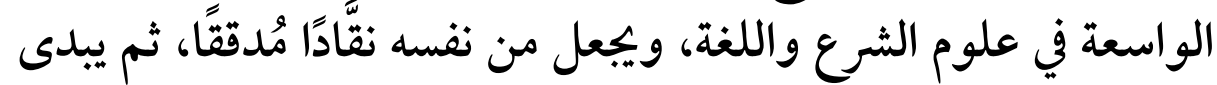

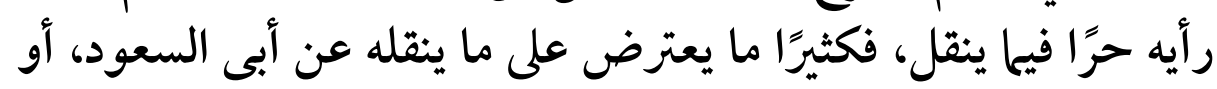

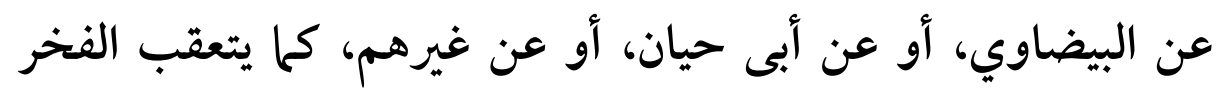

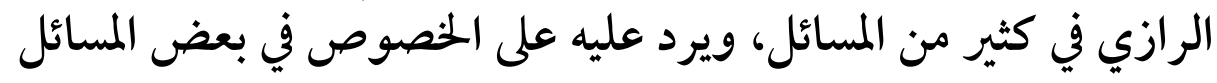

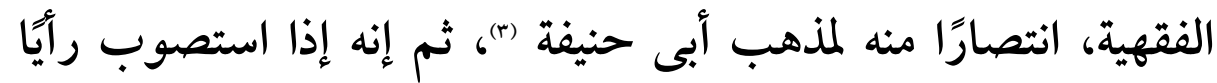

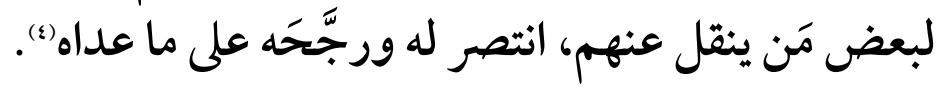

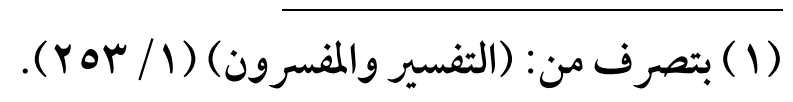

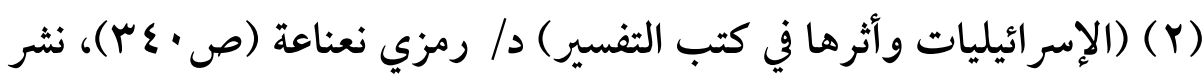

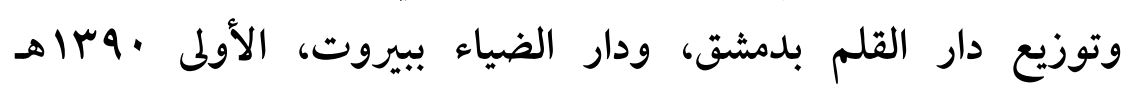

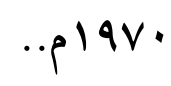

( ( ( ) الذي كان يفتي به لما تقلد الإفتاء.

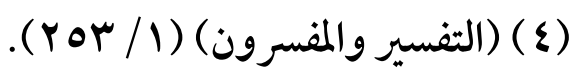


وفعله هذا دليل على قابلية التراث الإسلامي للدراسة والتحقيق

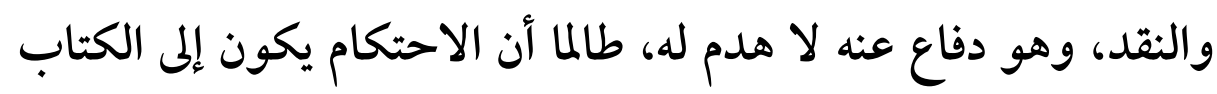
والسنة والعقل السليم ومبادئ البحث العلمي وقوانينه المعروفة لدى أهل العلم، وهذا هو معيار الحق والإنصاف.

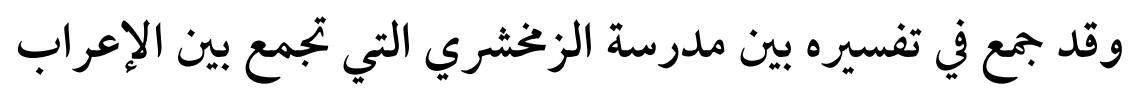
وإبراز النظم البلاغي للفظ القرآني المعجز، ومدرسة أبي حيان التي تهتم

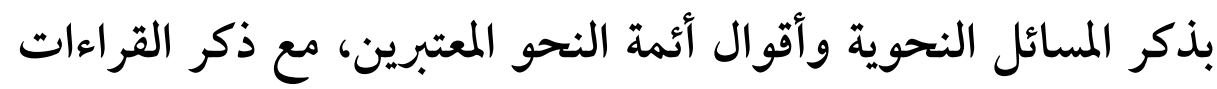

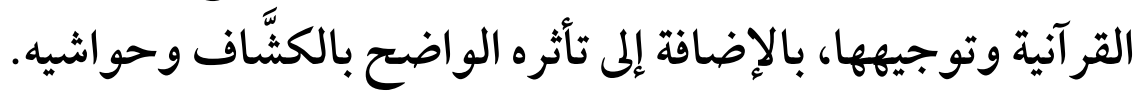

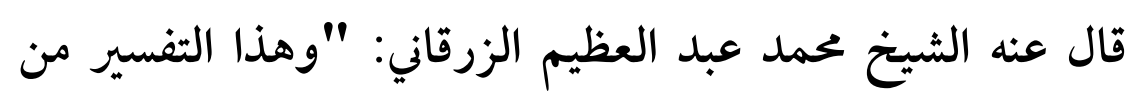
أجل التفاسير وأوسعها وأجمعها نظم فيه روايات السلف بجانب آبـ آراء الخلف المقبولة وألف فيه بين ما يفهم بطريق العبارة وما يفهم بطريق الإشارة رحمه الله وتجاوز عنه" (1).

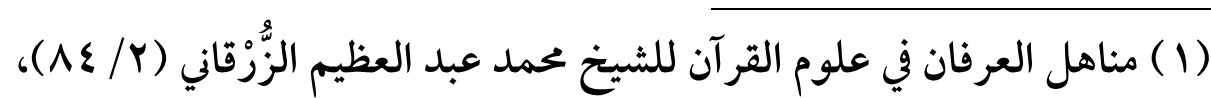
مطبعة عيسى البابي الحلبي وشر كاه، الطبعة الثالثة. 


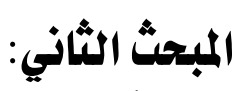

الإسرائيليات، وموقف الإمام الألوسي منها، وأقسامها في تفسيره،

$$
\text { وطريقته في نقدها }
$$

وأذكر فيسه معنى الإسرائيليـات، وموقـف الإمـام الألوسي منهـيا،

$$
\text { و أقسام الإسرائيليات في تفسيره، وطريقته في نقدها. }
$$

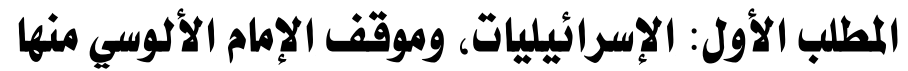

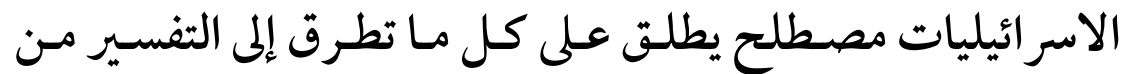

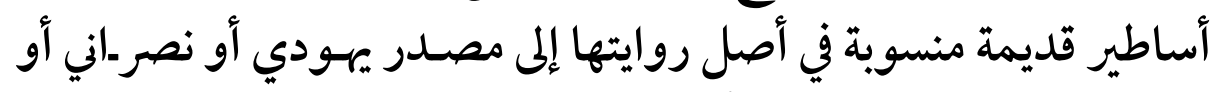

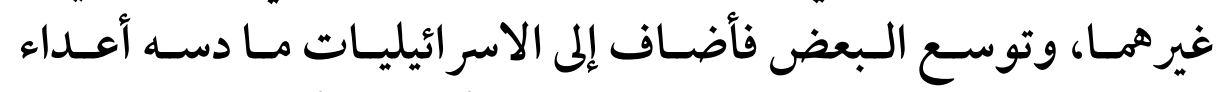

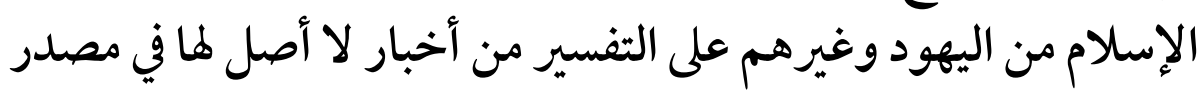

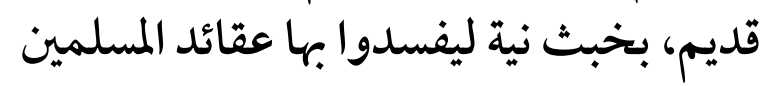

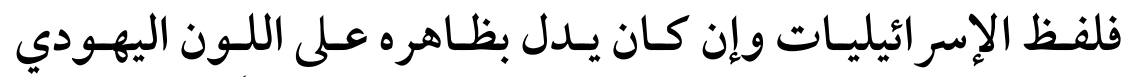

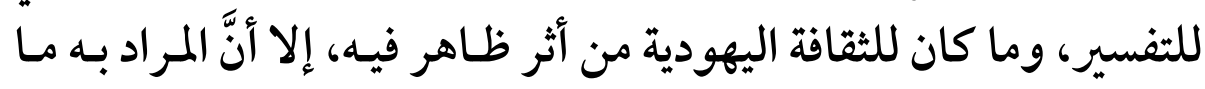

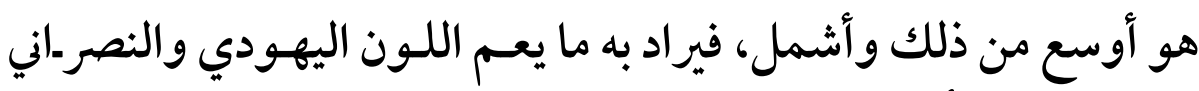
للتفسير، وما تأثر به التفسير من الثقافتين اليهودية والنصر الثرانية وغير هما.

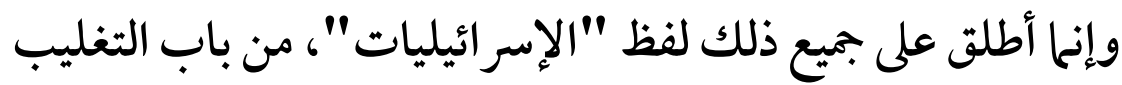

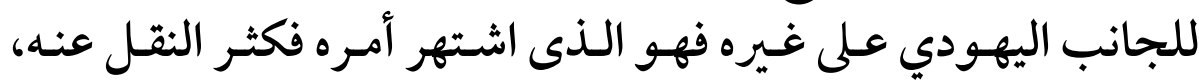

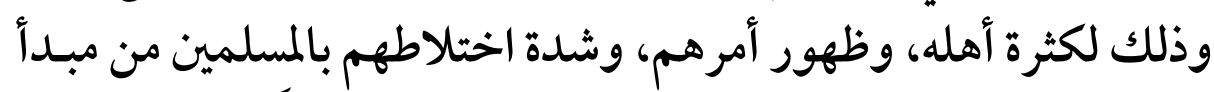

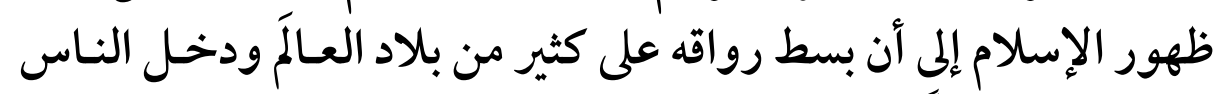
في دين الله أفواجاً (الان.

(1) ينظر: (الإسرائيليات في التفسير والحديث) دم/ محمد حسين الذهبي (ص (1) : 10 ) طبعة مكتبة وهبة بالقاهرة، بدون سنة الطبع. 
والإمام الألوسي كان "شديد النقد للإسرائيليات والأخبار

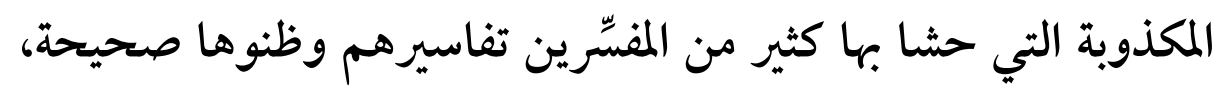

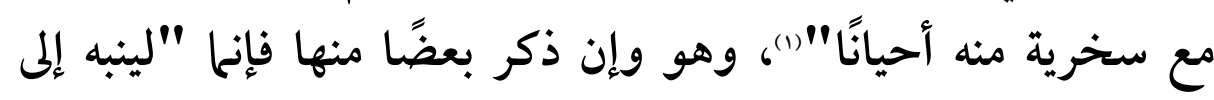

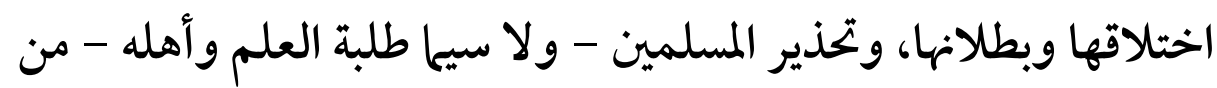

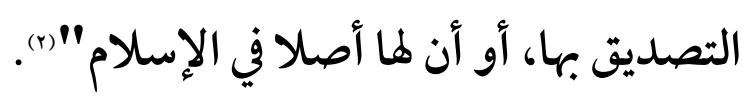

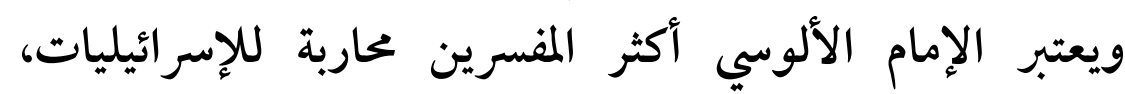

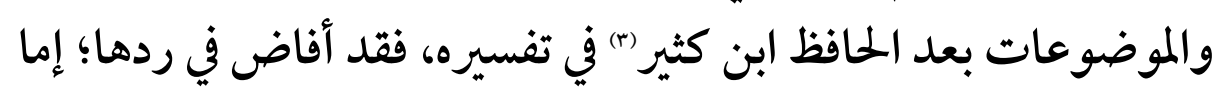

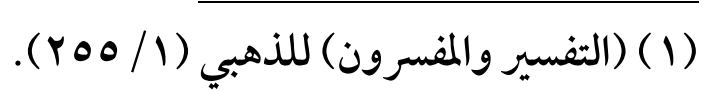

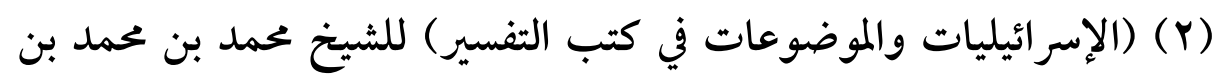

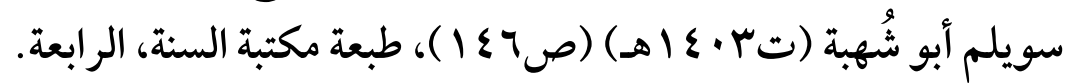

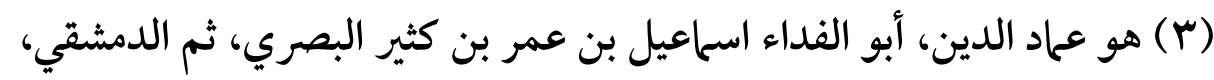

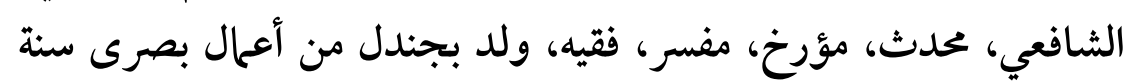

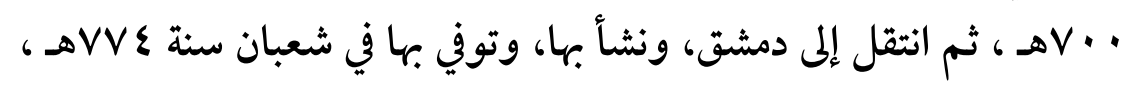

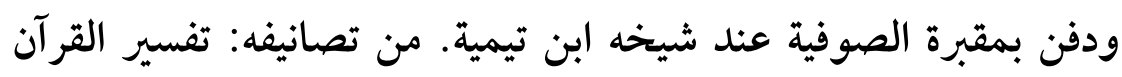

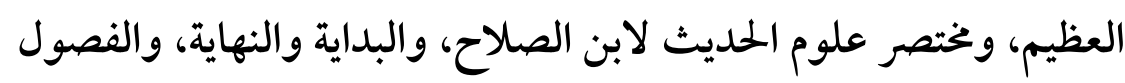

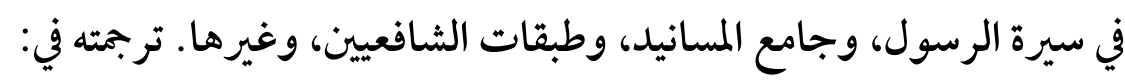

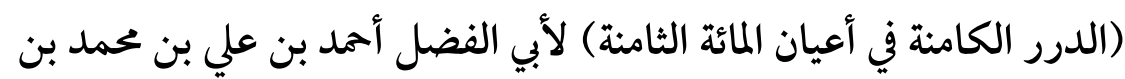

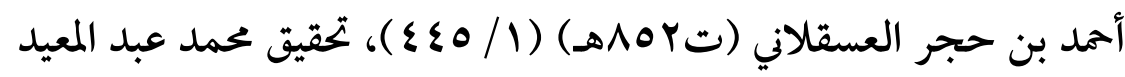

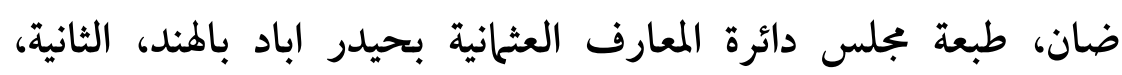

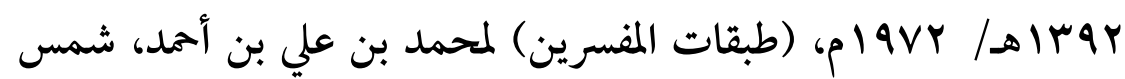


لمخالفتها العقل، أو المعلوم من الثرع، أو أنها تمس من عصمة الأنبياء،

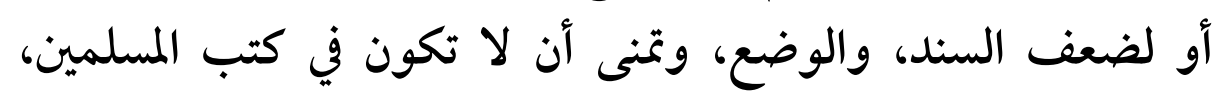

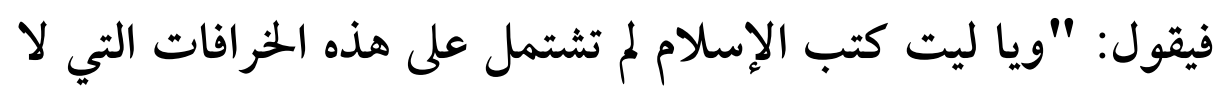

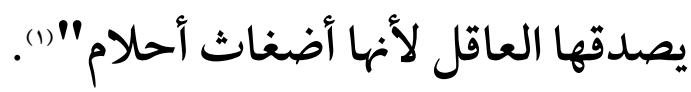

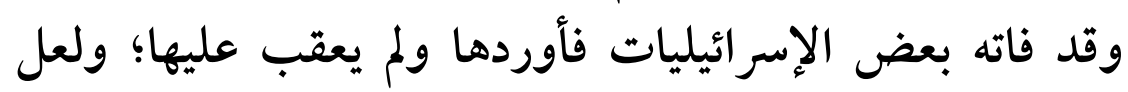

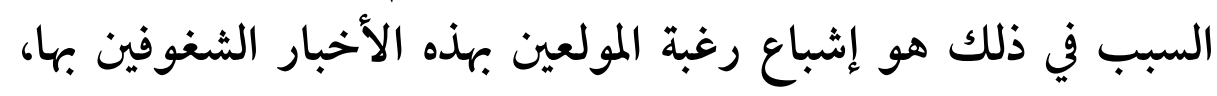

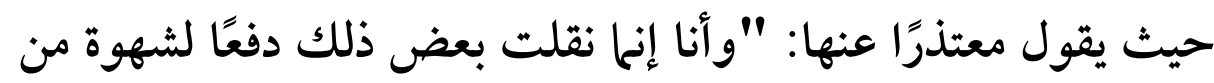
يجب الاطلاع على شيء من أخبارها صدقًا كان أو كذبًا "(s).

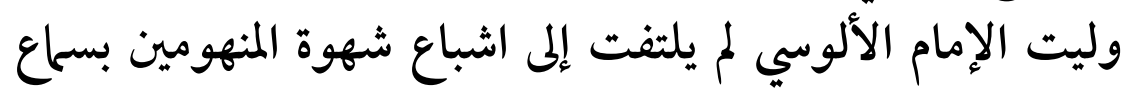

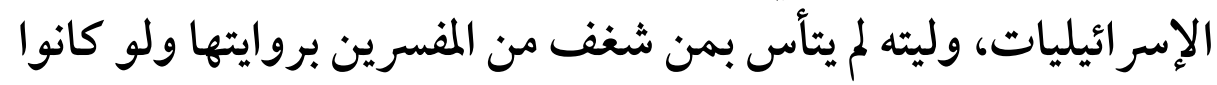

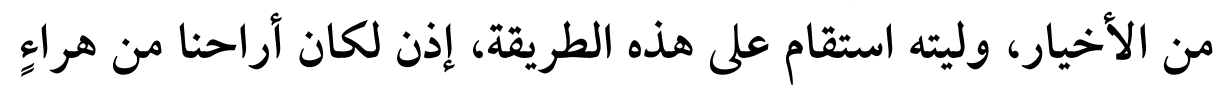

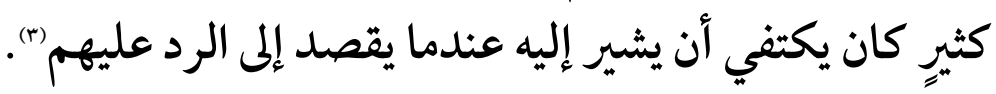

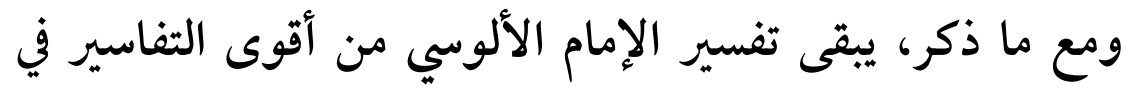

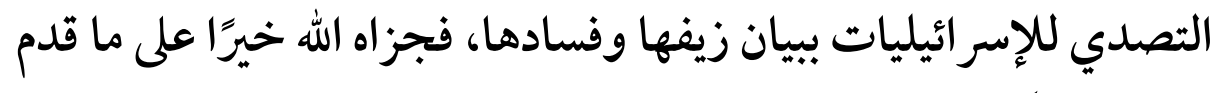

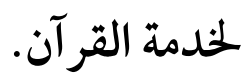

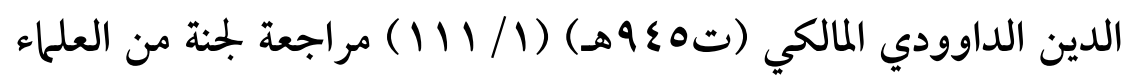

$$
\begin{aligned}
& \text { بإشر اف الناشر، طبعة دار الكتب العلمية. }
\end{aligned}
$$

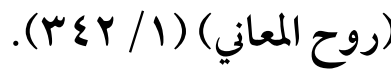

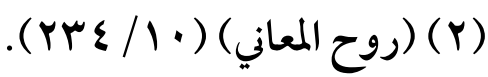

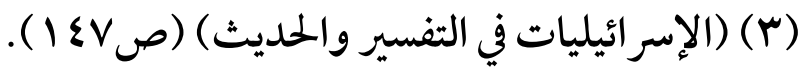


(YrI)

المطلب الثاني: أقسام الإسرائيليات في تفسير الإمام الألوسي

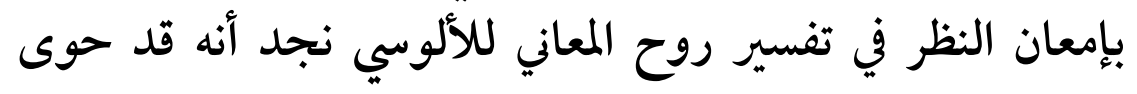

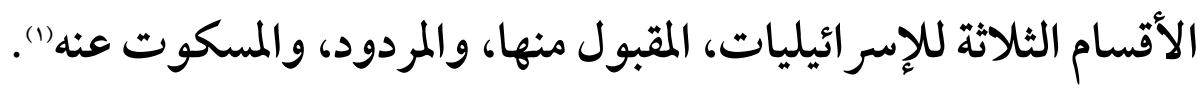

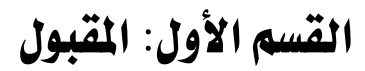

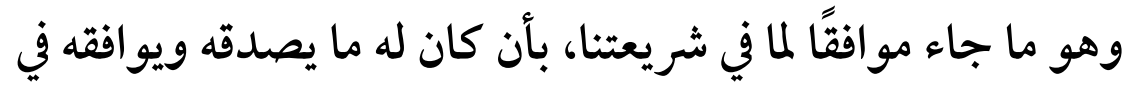

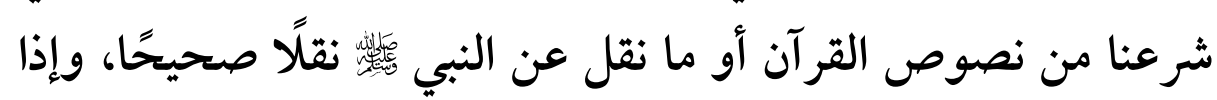
ذُكر فإنحا يذكر استشهادًا لا اعتقادًا (r).

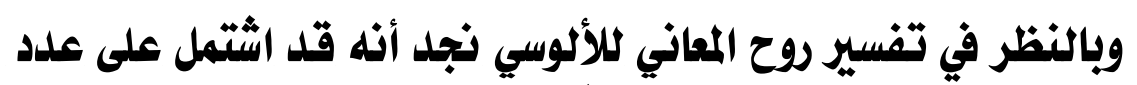

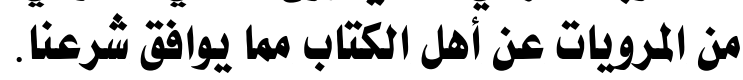

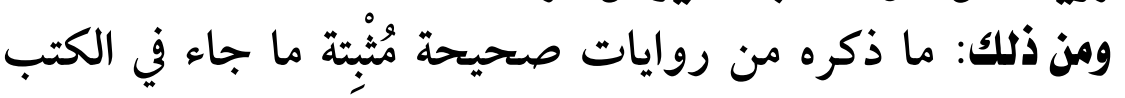

السابقة من ذكر صفة النبي

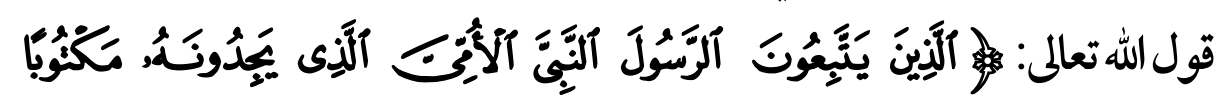

(1) وهو أقدم تقسيم معروف، وقد ذكره ابن تيمية في مقدمته في أصول التفسير،

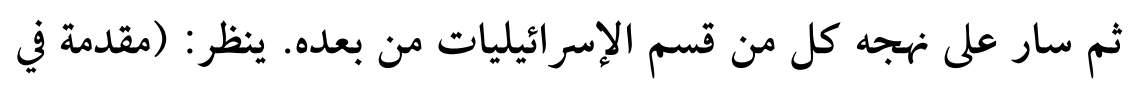

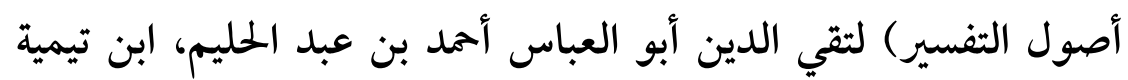

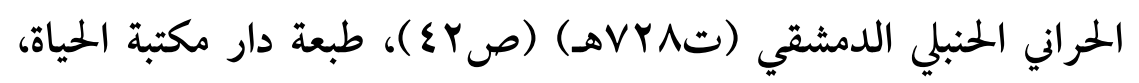

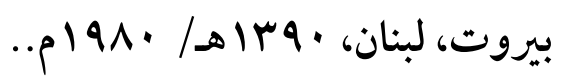

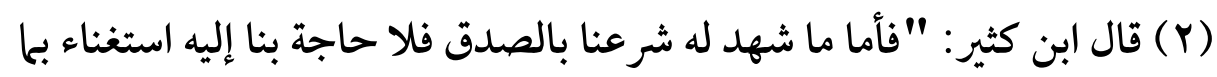

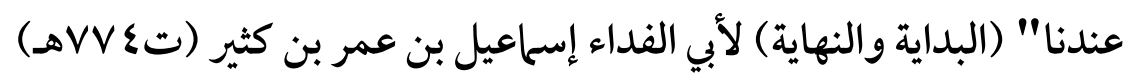

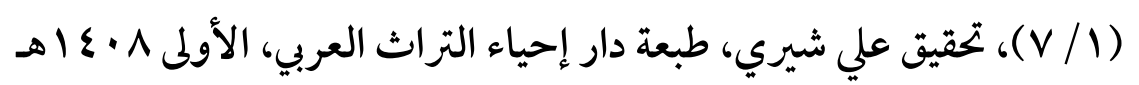




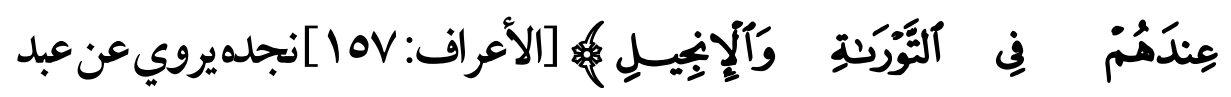

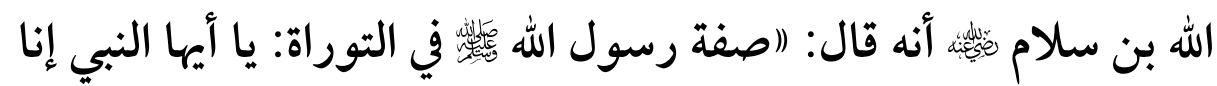

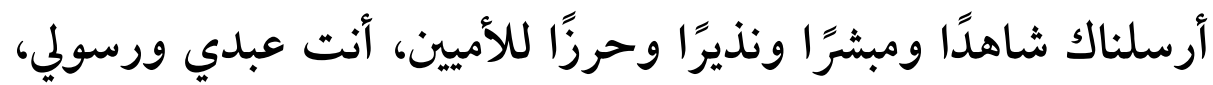

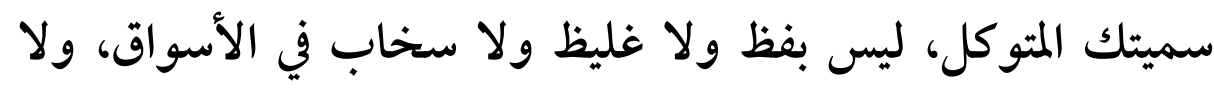

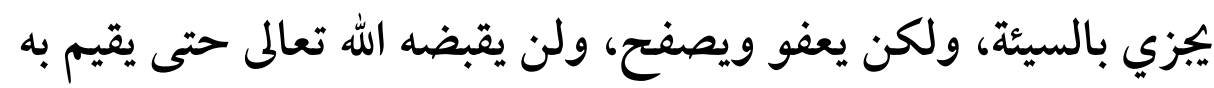
الملة العوجاء حتى يقولوا: لا إله إلا الله، ويفتح أعينًا عميًا وآذانًا صيًا وقلوبًا غلفًا)(1).

ثم يسوق روايتين، الأولى؛ عن سهل مولى خيثمة، فيها صفة رسول الله

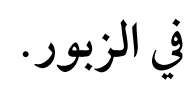
ثم يقول: إلى غير ذلك من الأخبار الناطقة بأنه لِّ

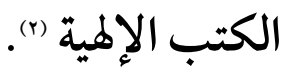

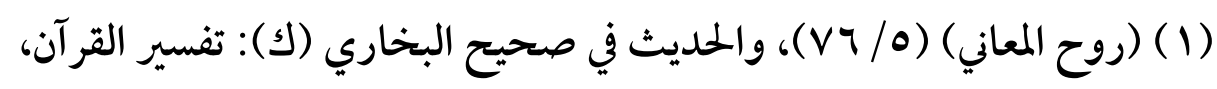

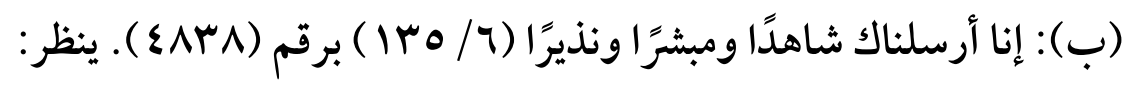

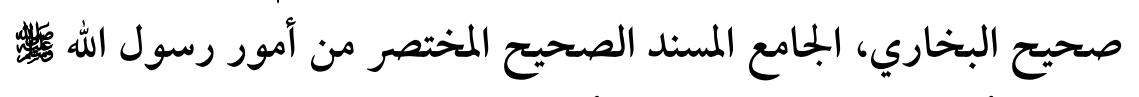

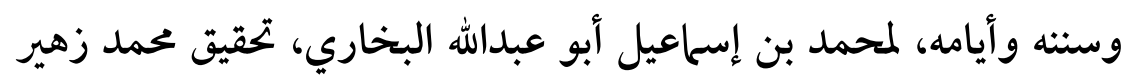

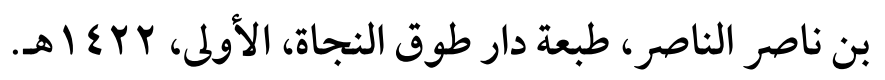

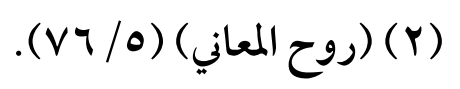


(rrr)

وما ورد من روايات ساقها الإمام الألوسي في صفة النبي

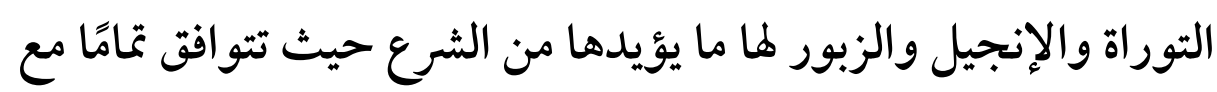

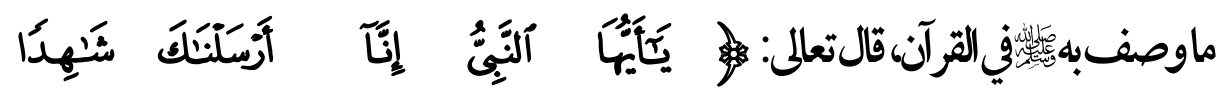

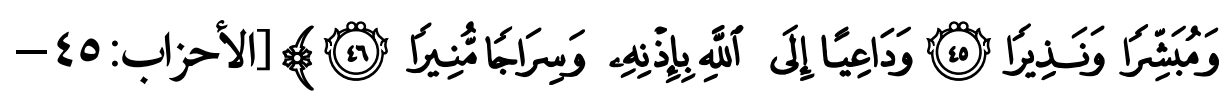

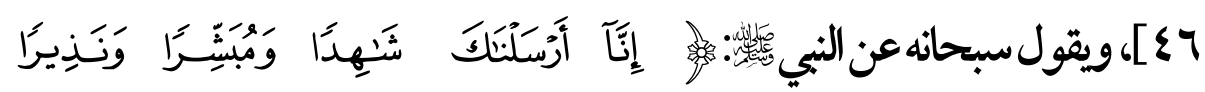
[الفتح: 1 ]، والقرآن هو المهيمن على الكتب السابقة فحا وافقه

\section{القشيم الثاني: المردود}

وهو ما عُلم كذبه بشهادة شرعنا له بالبطلان، كالأخبار التي ورد المردود

فيها الطعن في عصمة الأنبياء عليهم الصلاة والسلام، أو كان محا تحيله العقول السليمة، ويغلب على الظن كذبه، وهو أقرب إلى الخرافة؛

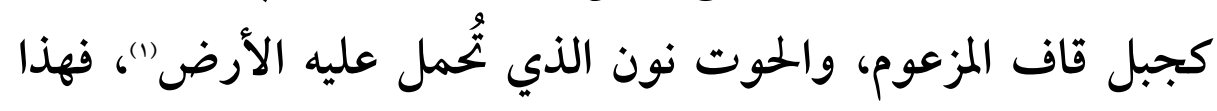
يجب رده وإطر احه، ولاتجوز حكايته إلا على سبيل التنبيه على بطلانه(r).

(1) وهذه المرويات الإسرائيلية لا يتقبلها عقل، وهي مخلفة للحس والمشاهدة،

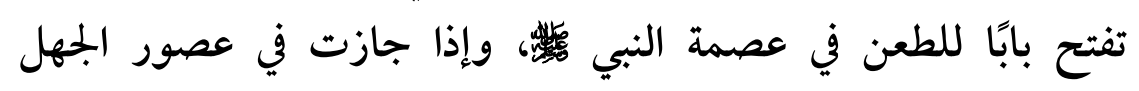

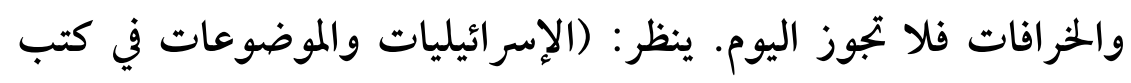

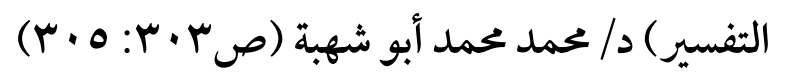

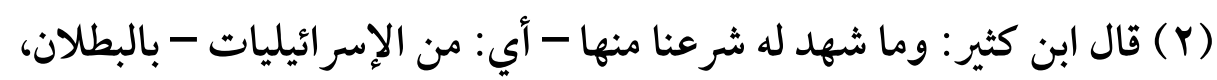
فذاك مردود لا ييوز حكايته؛ إلا على سبيل الإنكار والإبطال. (البداية

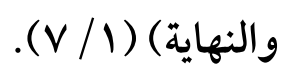


والإمام الألوسي حينما يذكر الروايات الإسرائيلية من هذا القبيل

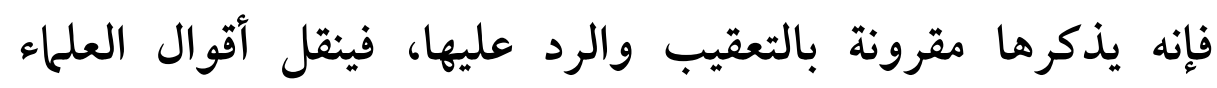

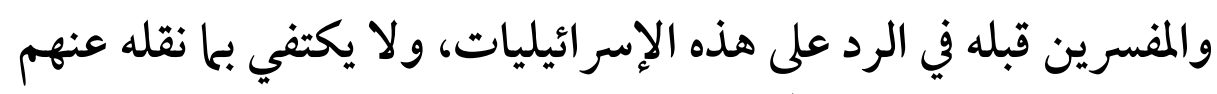

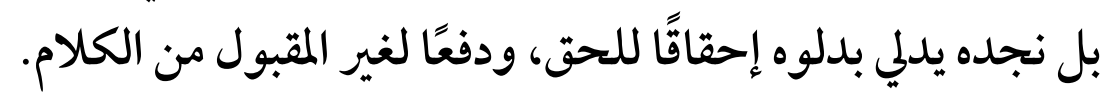

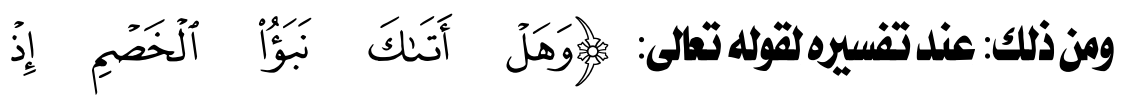

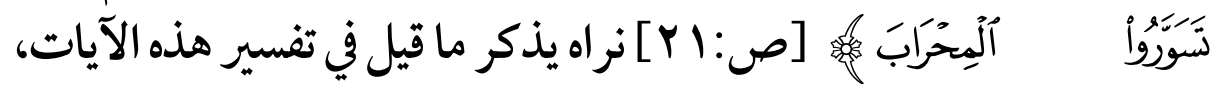

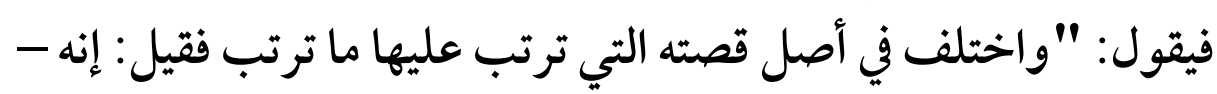

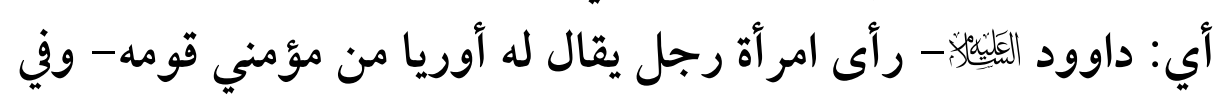

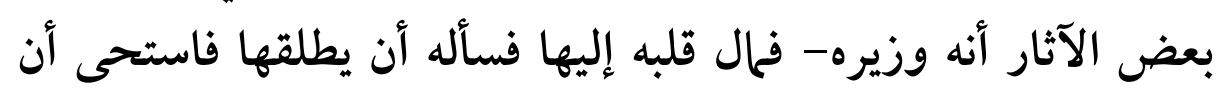

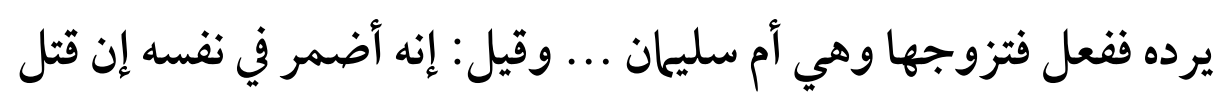

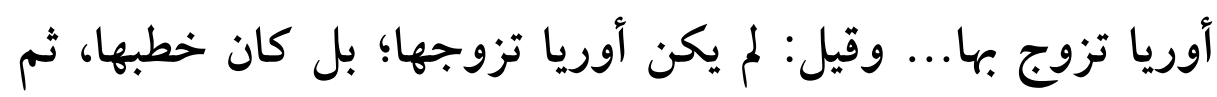

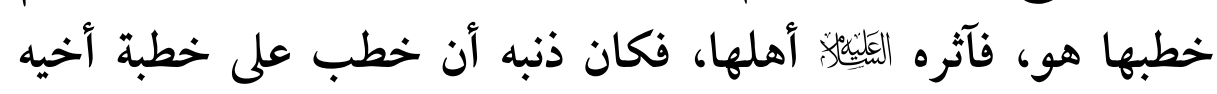

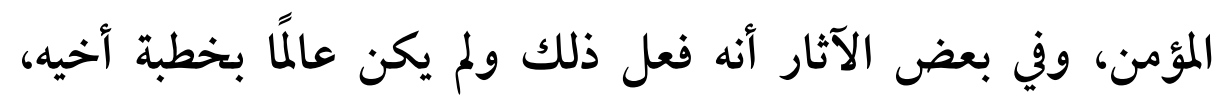

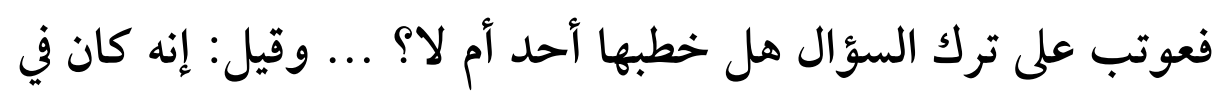

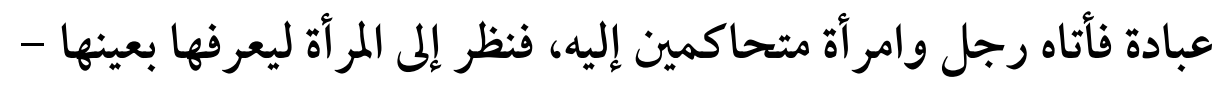

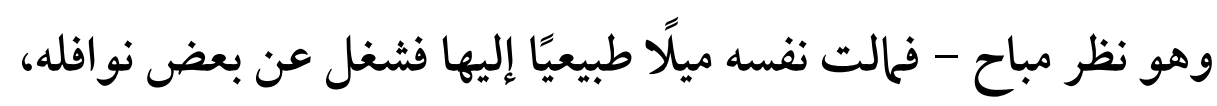

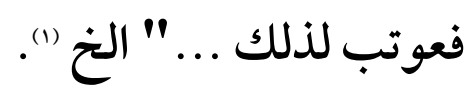

( (IVV/I ( ) (روح المعاني) (1) 
(rro)

ثم يعقب على ذلك بقوله : "والمقبول من هذه الأقوال ما بعد من

الإخلال بمنصب النبوة، وللقُصَّاص كلام مشهور لا يكاد يصح لما فلما فيه

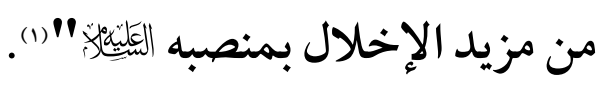

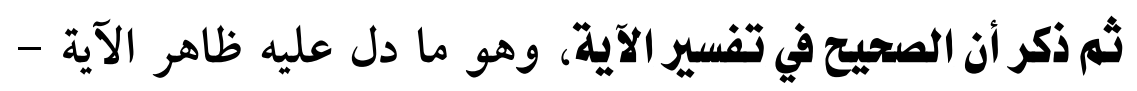

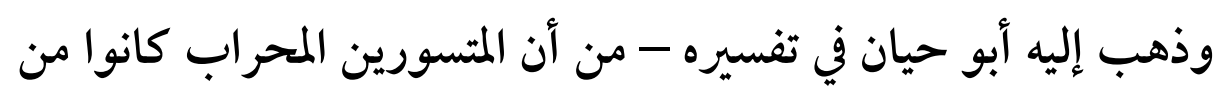

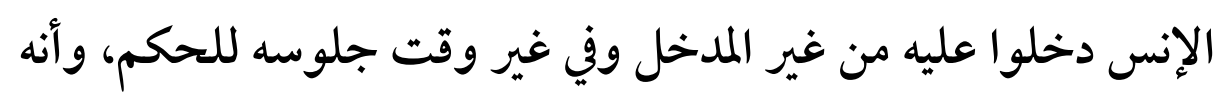

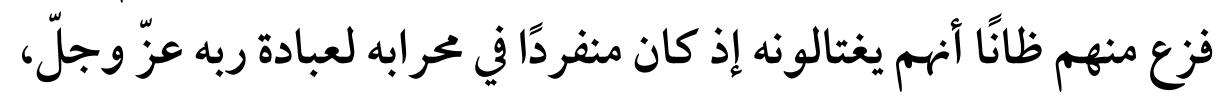

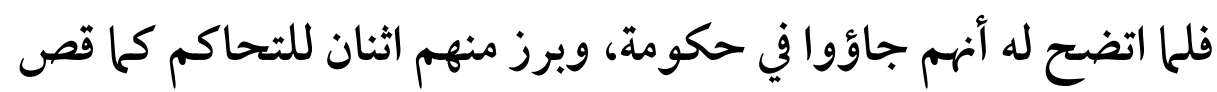

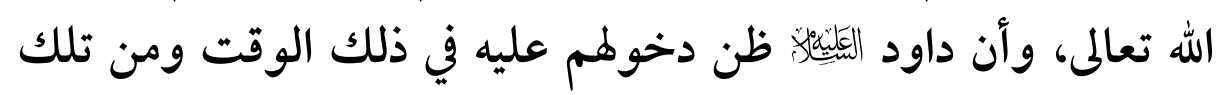

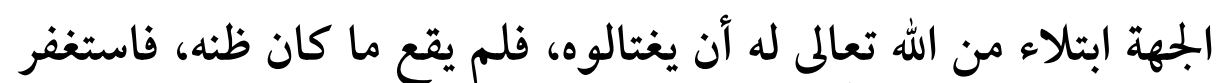

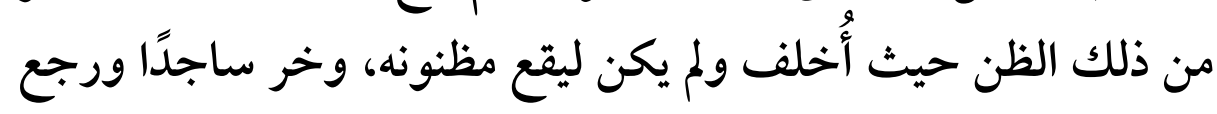

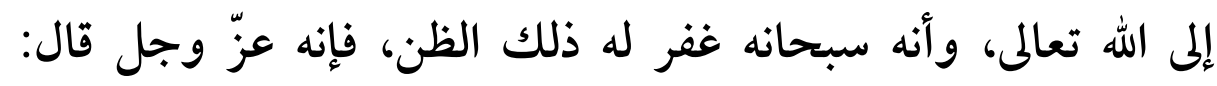

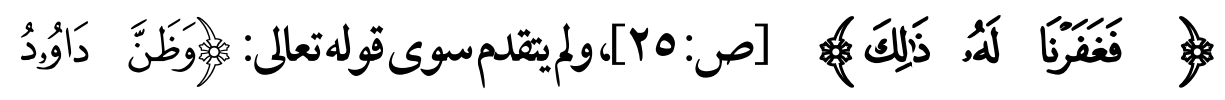

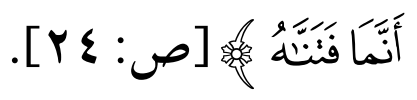

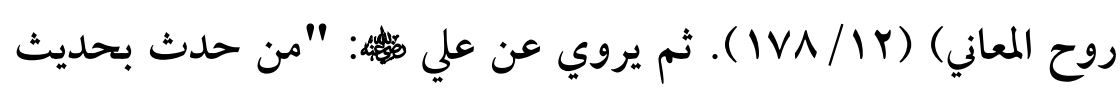

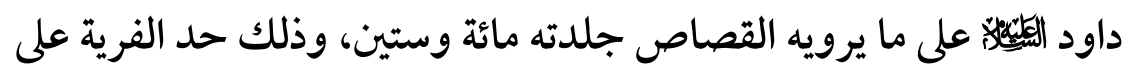
الأنبياء صلوات الله تعالى وسلامه عليهم أجمعين"، وهذا اجتهاد منه كرم الفهاص الله وجهه. 
(Yry) الإمام الألوسي وجهوده في نقد الإسرائيليات من خلال تفسيره روح المعاني

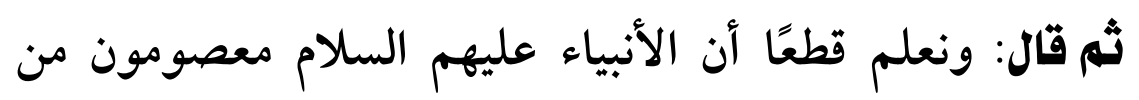

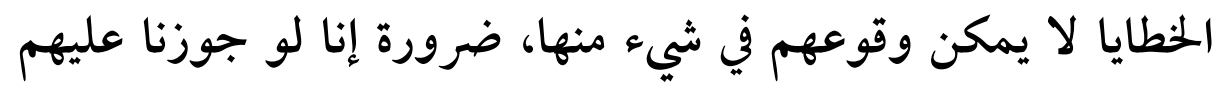

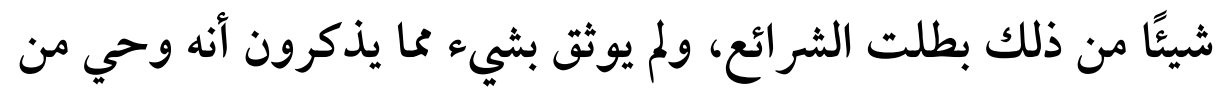

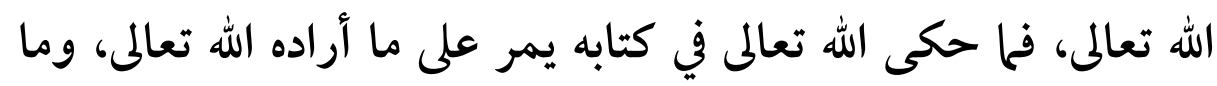

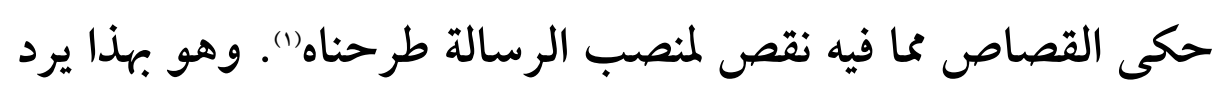

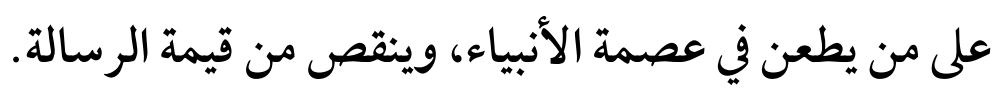

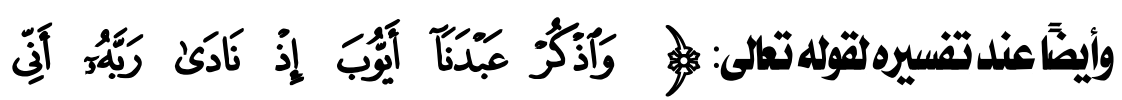

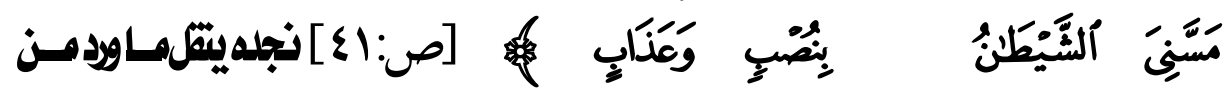

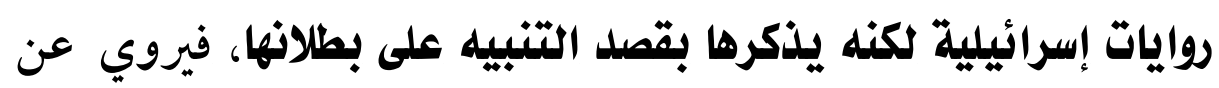

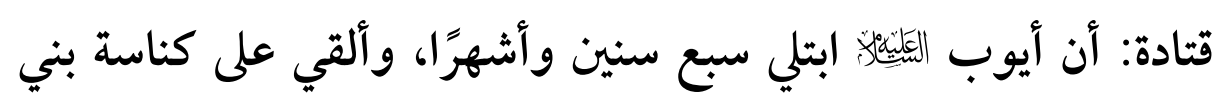

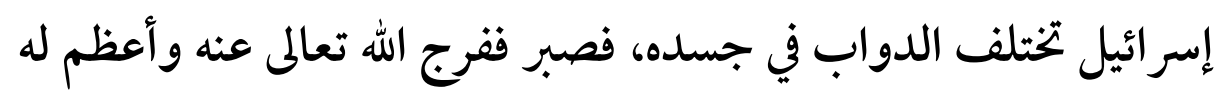

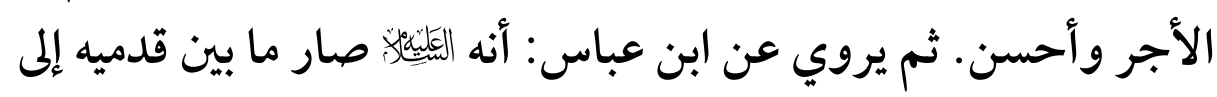

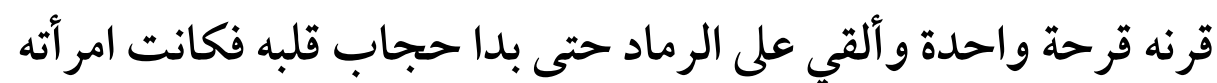

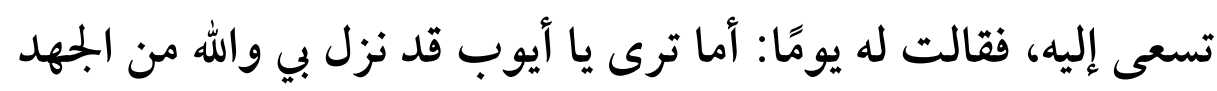

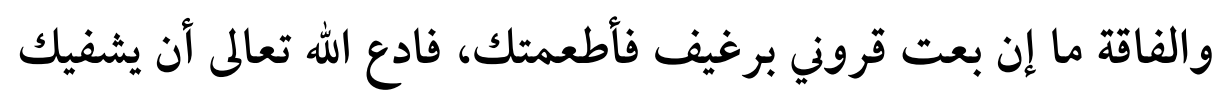

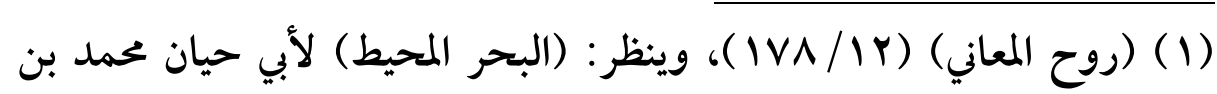

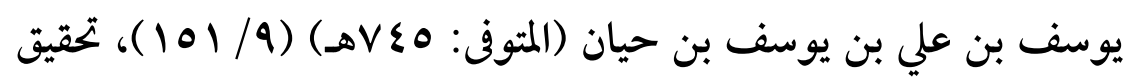

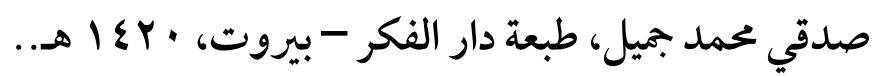


(rrv)

ويريحك فقال: ويحك كنا في النعيم سبعين عامًا فاصبري حتى نكون في الضر سبعين عامًا فكان في البلاء سبع سنين وئن ل.. الخ.

ثم نرى الإمام الألوسي يرد هذه الروائ الياءئ سنيات الباطلة وينكرها فهي

تتنافى مع حفظ الله تعالى لأنبيائه مما تعافه النفوس ويؤدي إلى نفرة الناس

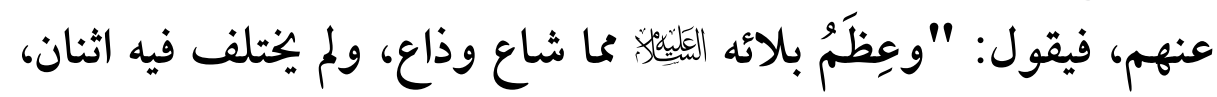

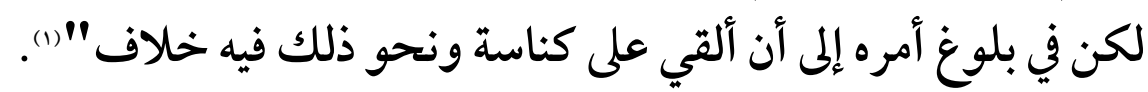

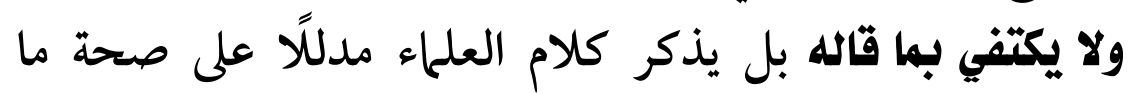

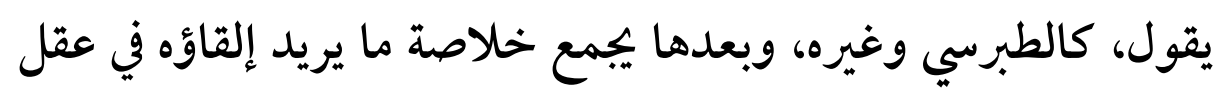

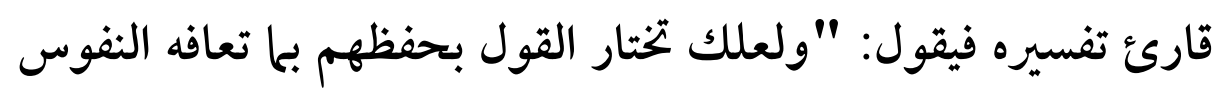

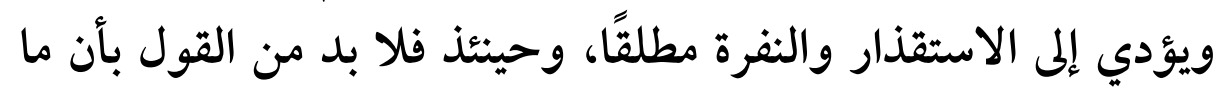

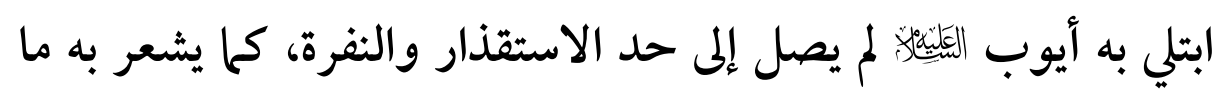

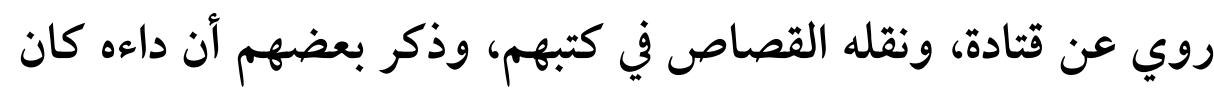
الجدري، ولا أعتقد صحة ذلك، والله تعالى أعلم" (r).

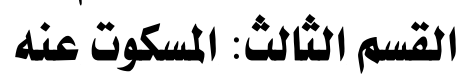

وهو ما لا تحيله العقول السليمة، ولا يغلب على الظن كذبه، الظعاله فحينئذ يكون التوقف، فلا يجكم عليه بصدق أو كذب، ويحمل عليه

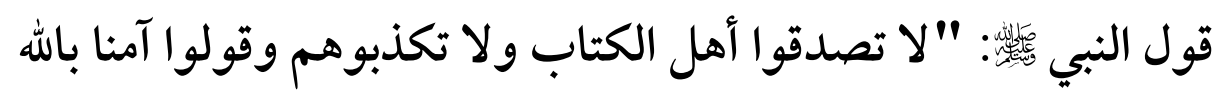

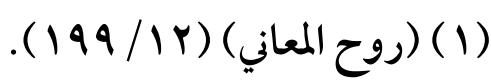

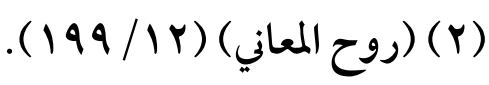


وما أنزل إلينا"(()، والتوقف، معناه: التوقف في التصديق والتكذيب؛

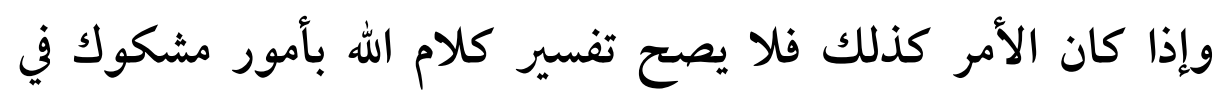
صدقها و كذبها (r) صان الهر

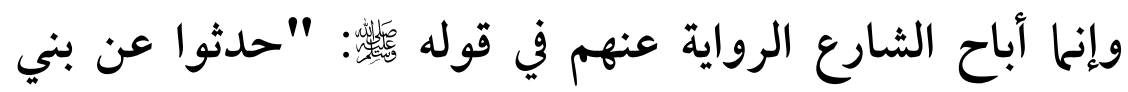

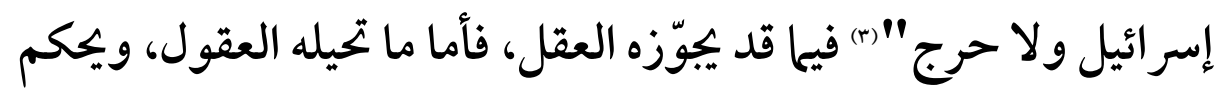
عليه بالبطلان، ويغلب على الظنون كذبه، فليس من هذا القبيل (s).

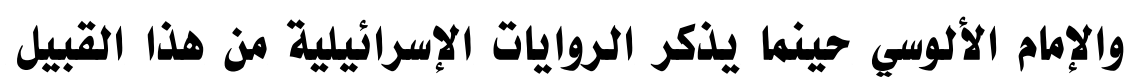

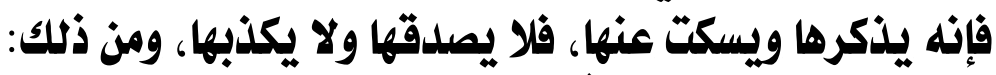

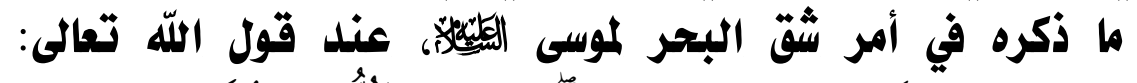

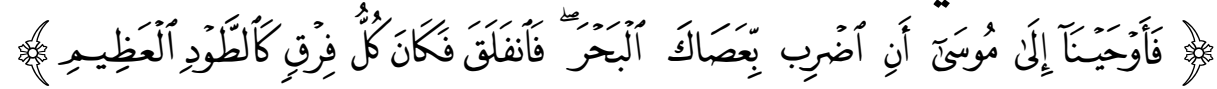

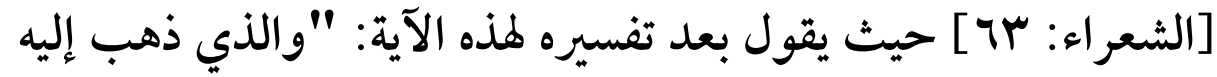

(1 ) أخرجه البخاري في صحيحه (ك): تفسير القرآن، (ب): قولوا آمنا بالله وما

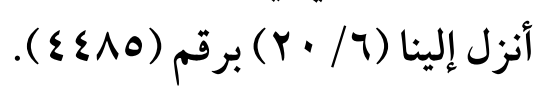

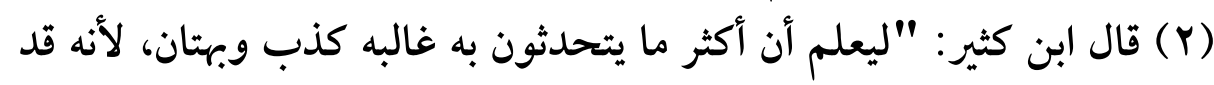

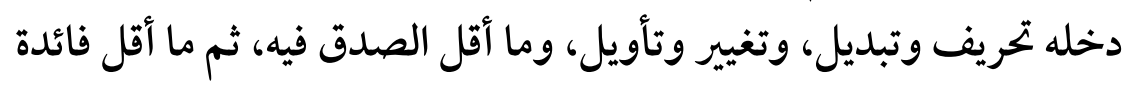

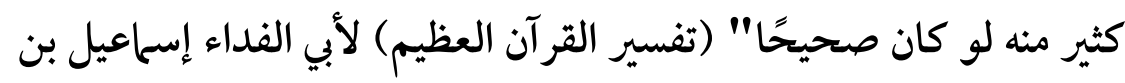

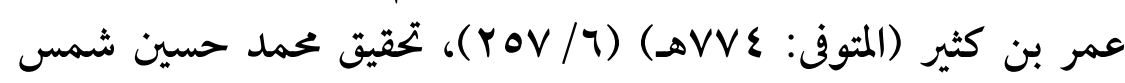

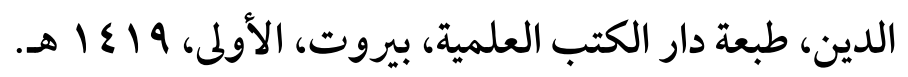

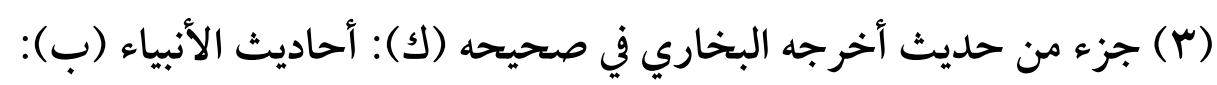

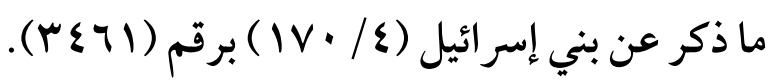

$$
\begin{aligned}
& \text { (تفسير ابن كثير) ( }
\end{aligned}
$$


أهل الكتاب أن الانفلاق كان خطيًا، وأن المسالك اثني عشر مسلكًا،

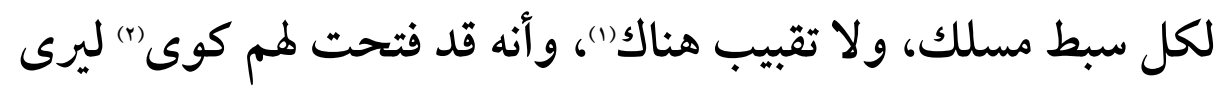
القريب قريبه، ويرى الرجل من سبط زوجته من سبط آخر، وأنهم

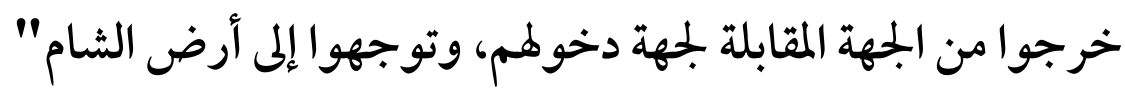

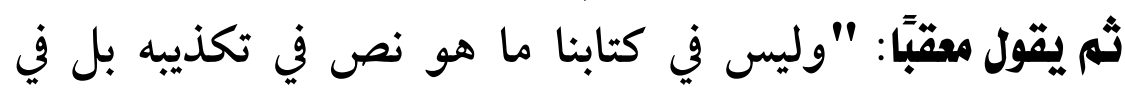
الأخبار ما يشهد بصحة بعضه، واتحاد الفروق والمسالك في العدد يحتاج

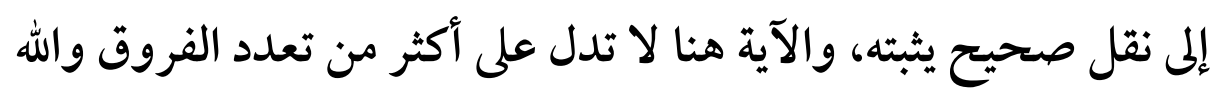
تعالى أعلم (r). وهنا نجد أن الإمام الألوسي يرفض تكذيب هذه الرواية، ولكنه يبين أن كل ما ورد فيها وليس له دليل صحة عندنا فهو يحتاج في إثباته إلى دليل.

(1) التقبيب: هو شكل يبتدئ من نقطة وينتهي إلى محيط دائرة ويسمى أيضًا:

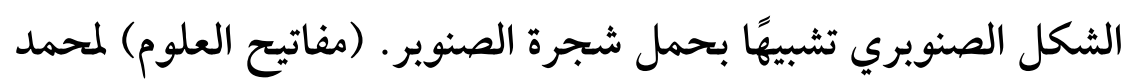

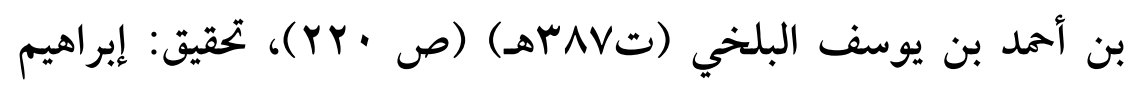
الأبياري، طبعة دار الكتاب العربي، الثانية.

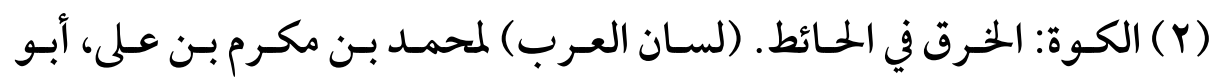

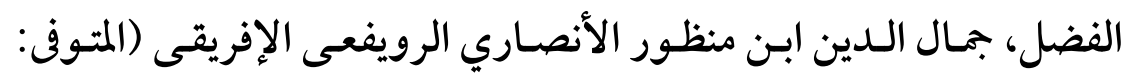

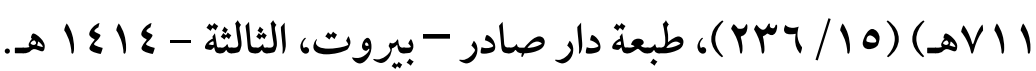

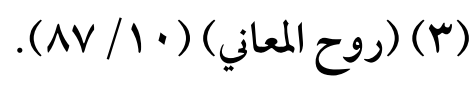


المطلب الثالث: طريقة الإمام الألوسي في نقد الإسرائيليات

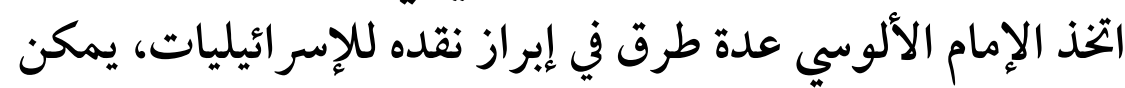

أولاً: نقد الإسرائيليات نقلًا عامًا على سبيل الإجمال

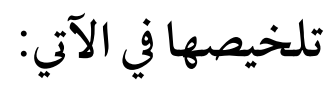

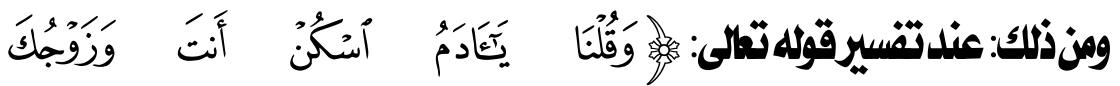

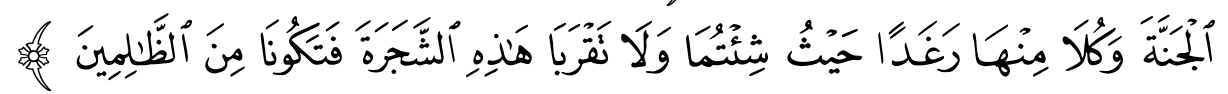

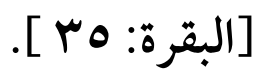

نجلده ينقل الأقوال في تعيين الشجرة فيقول: "ووقع خلاف في هذه الشجرة، فقيل: الحنطة، وقيل: النخلة، وقيل: شجرة الكافور - ونسب إلى علي كرم الله تعالى وجهه - وقيل: التين، وقيل: وفيل: الحنظل، وقيل وقيل: شجرة المحبة، وقيل: شجرة الطبيعة والموى، وقيل ..." (1).

ثم يقول: "والأولى عدم القطع والتعيين، كحا أن الله تعالى لم يعينها باسمها في الآية، ولا أرى ثمرة في تعيين هذه الشجرة "(s).

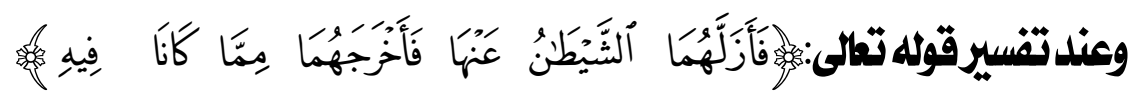

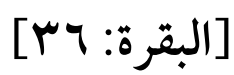

نجلده ينقل حيل اللعين إبليس على آدم وحواء ليأكلا من الشجرة،

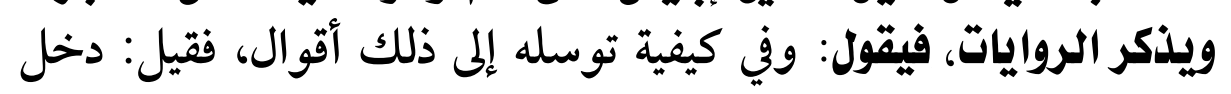

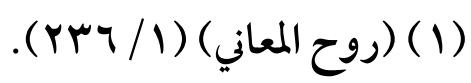

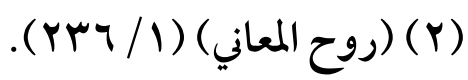


الجنة ابتلاء لآدم وحواء، وقيل: قام عند الباب فناداهما وأفسد حالهما،

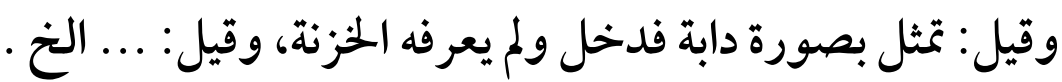

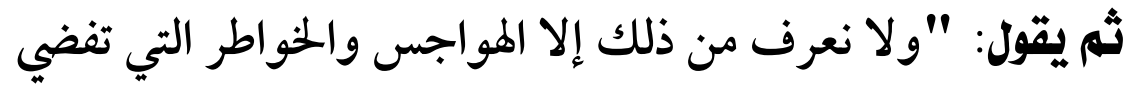
إلى ما تفضي" "(1) ولا شك أن هذه الروايات تسربت إلى كتب التفسير من كتب أهل

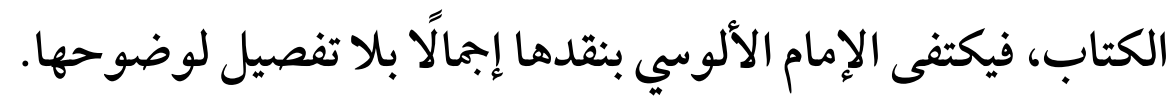

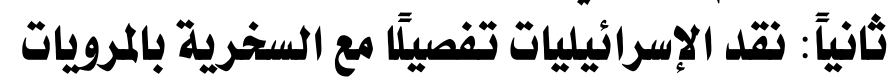

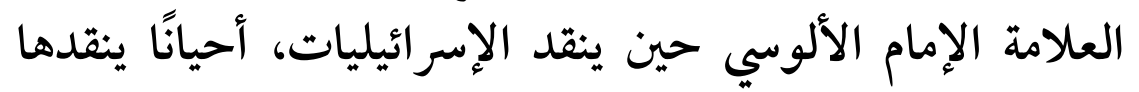

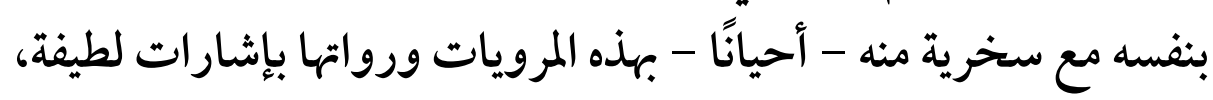
وتلميحات طريفة لا تخرج به دنيا الأدب الذي يجب التبان أن يتحلى به العلم|ء

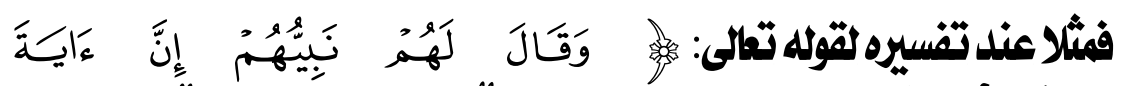

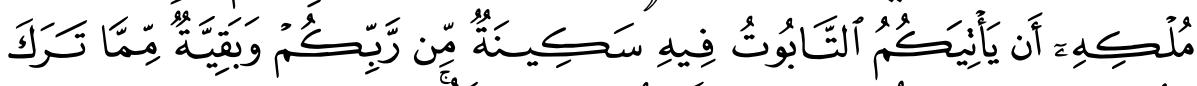

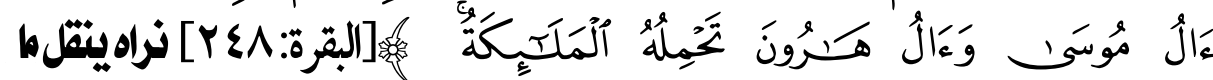
قاله أهل الأخبار في شأن التابوت من أنه صندون

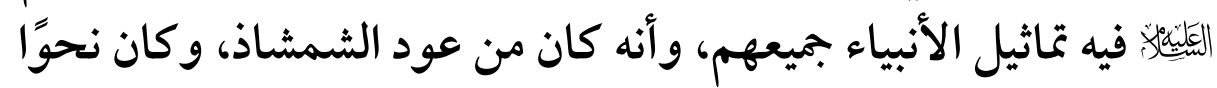

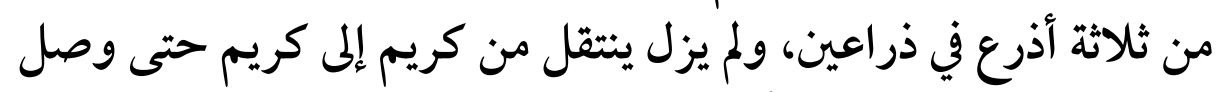

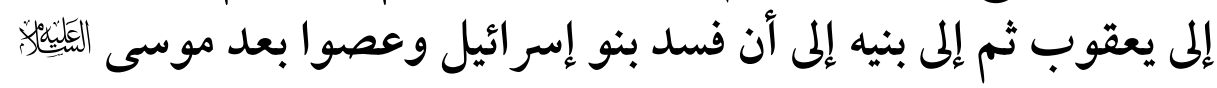

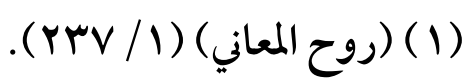

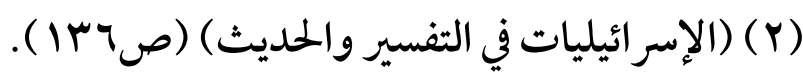


فسلط الله تعالى عليهم العحالقة فأخذوه منهم فجعلوه في موضع البول

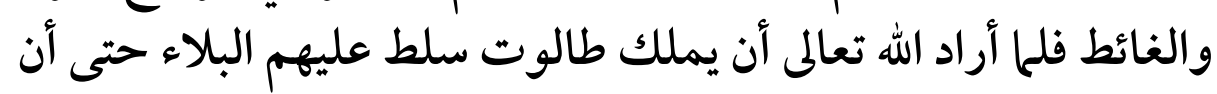

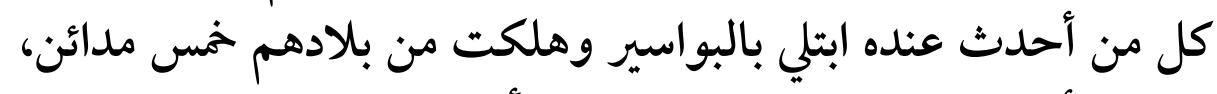

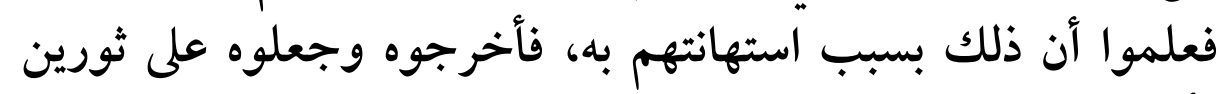

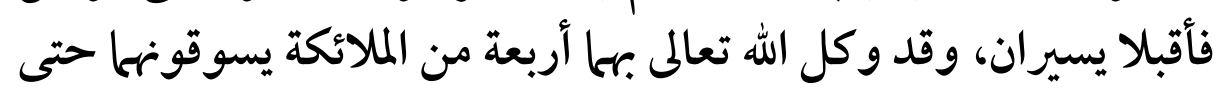

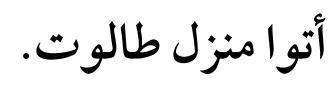
وبعد أن ساق هذا الخبر وغيره، عقَب ساخرًا: "ولم أر أر حديثًا صحيخًا مرفوعًا يعول عليه يفتح قفل هذا الصندوق ولا فكرًا كذلك "(1).

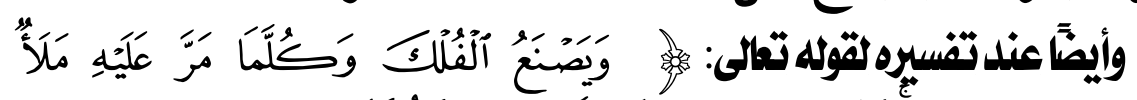

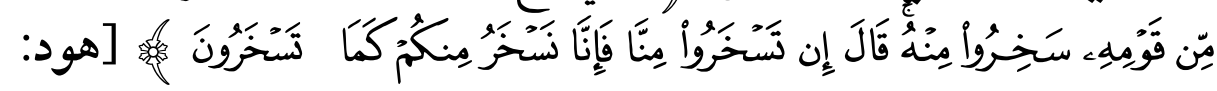

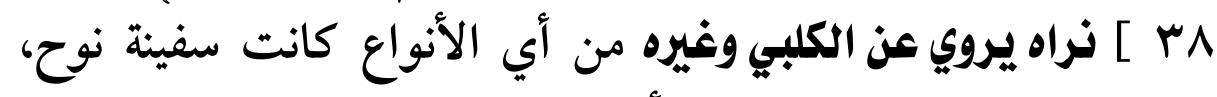

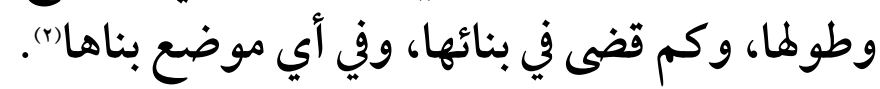

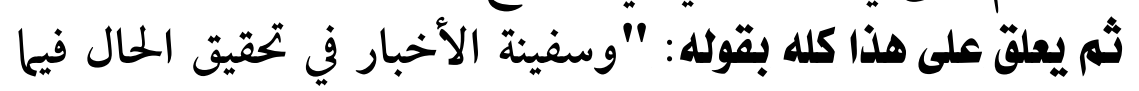

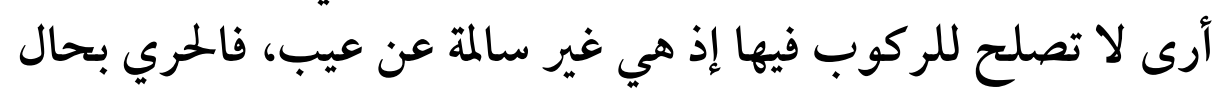

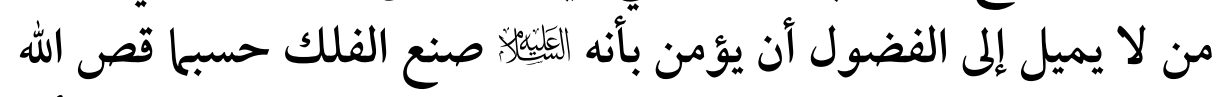

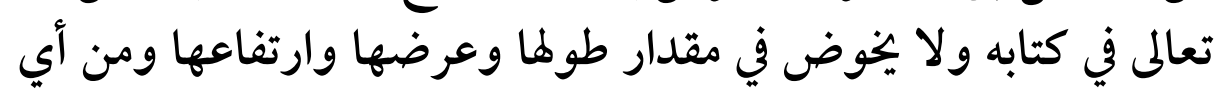

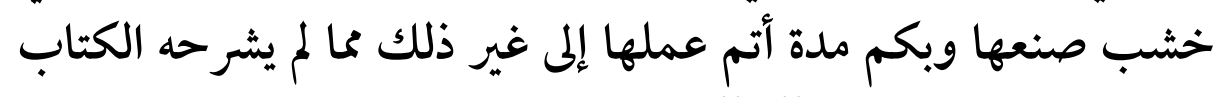
ولم تبينه السنة الصحيحة "(r)" ".

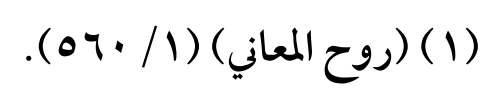

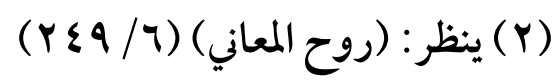

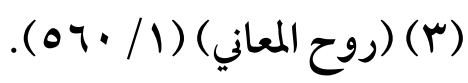


ثالثأ: نقل نقل غيره من العلماء مع علدم التعليق اكتفاء بما نقل

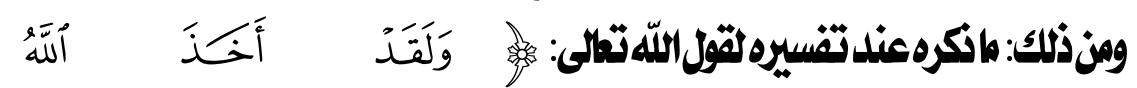

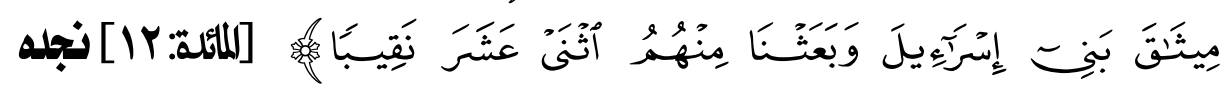

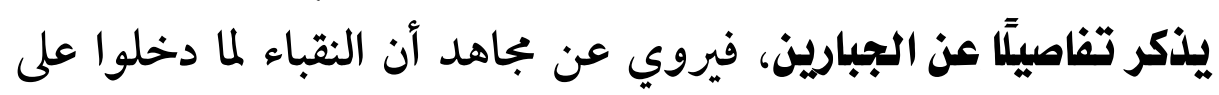
الجبارين وجدوهم يدخل في كم أحدهم اثنان منهم، ولا يحمل عنقود فئردي

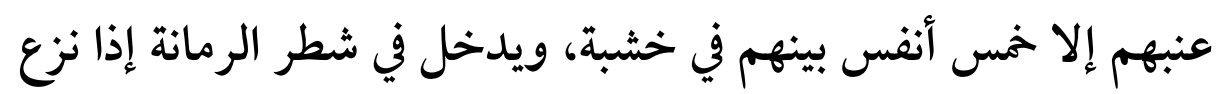

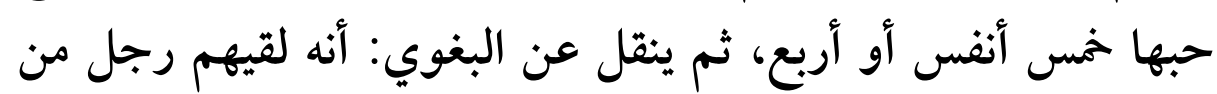

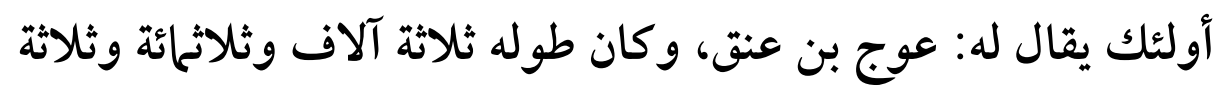
وثلاثين ذراعًا وثلث ذراع، وكان يكتجز بالسحاب ويشرب ونئ منه،

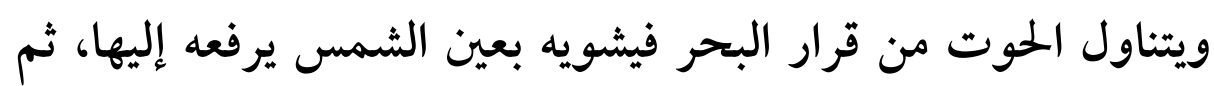

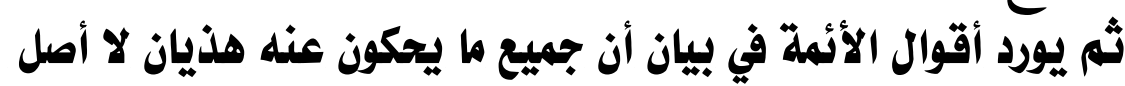
يأكله ...الخ.

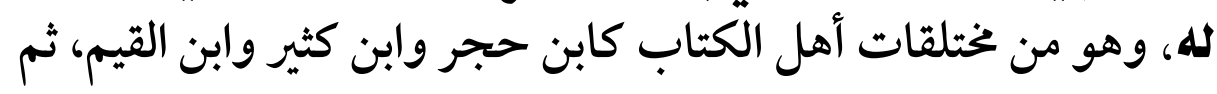

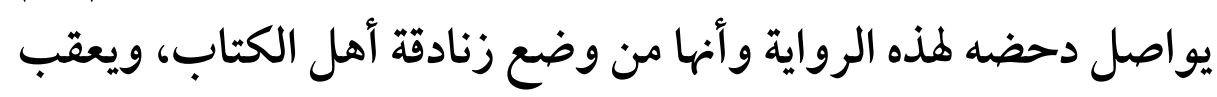
بعد ذلك عليها. فيقول: " قد شاع أمر عوج عند العامة ونقلوا فيه حكايات

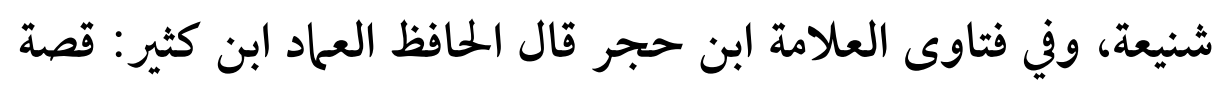

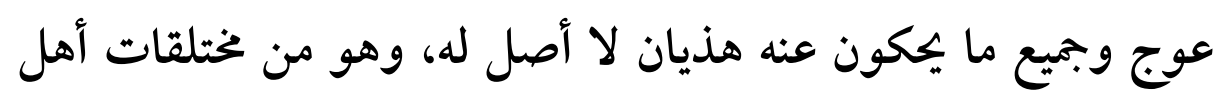

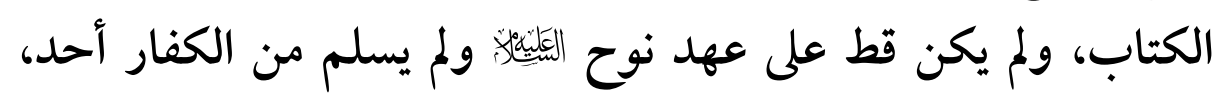




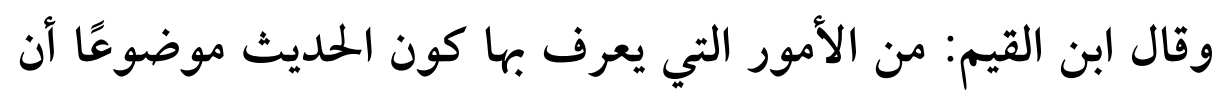

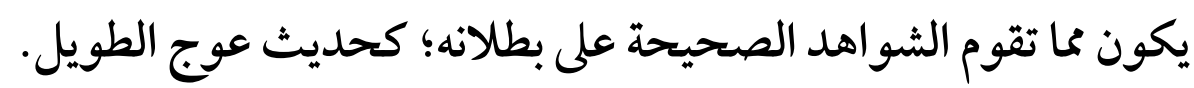

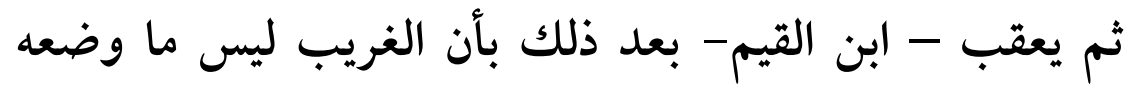

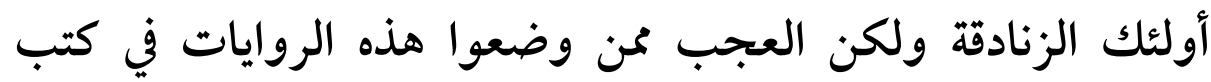

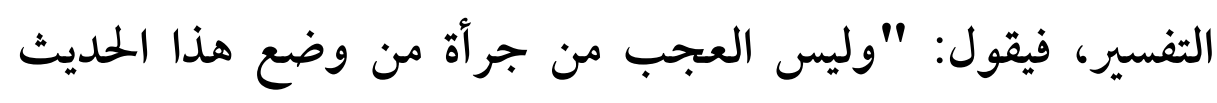

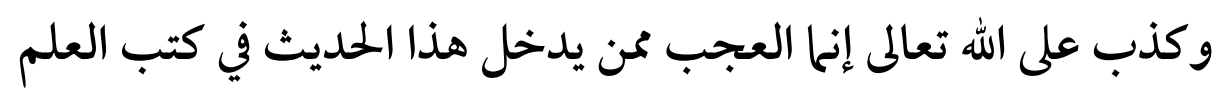

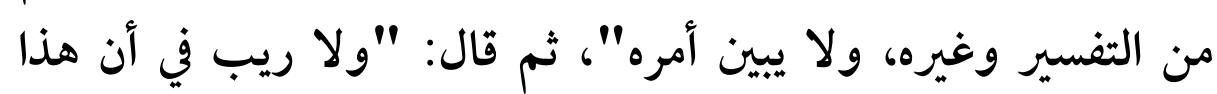

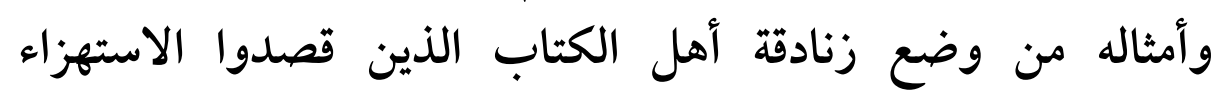

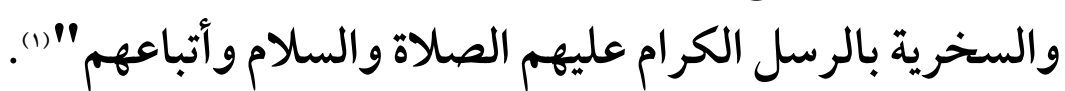

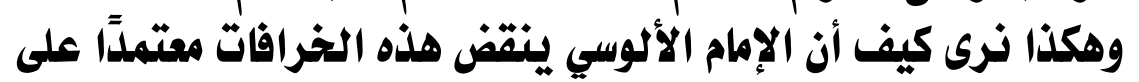

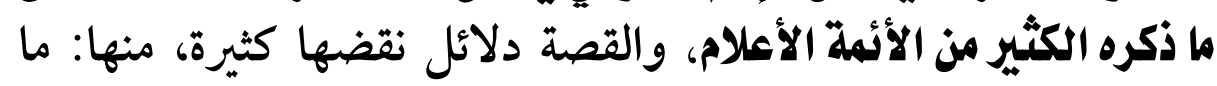

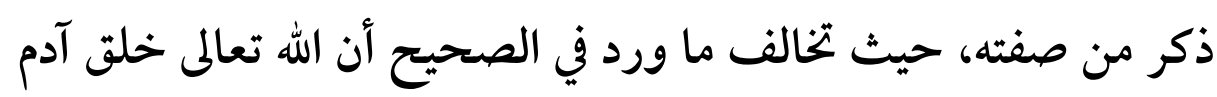

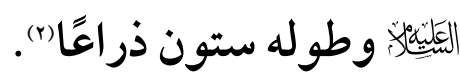

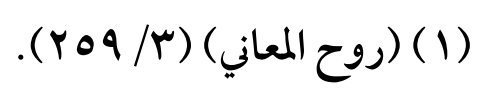

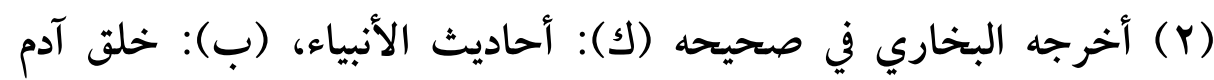

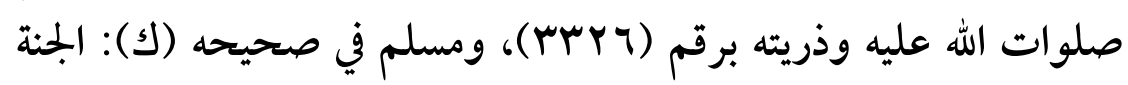

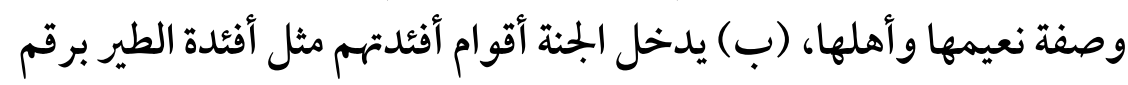
(Y^乏1)

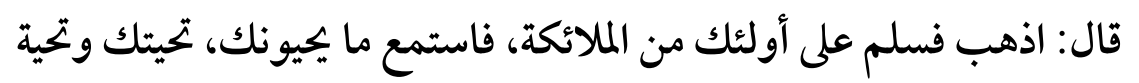
ذريتك، فقال السلام عليكم، فقالوا: السلام عليك ورهمة الله، فزادوه: 


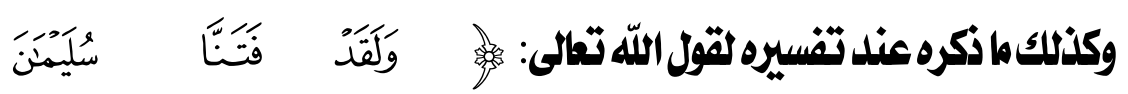

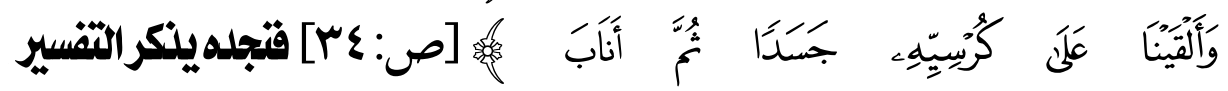

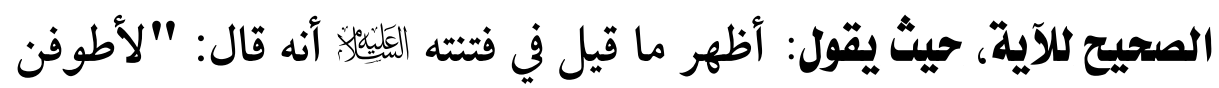

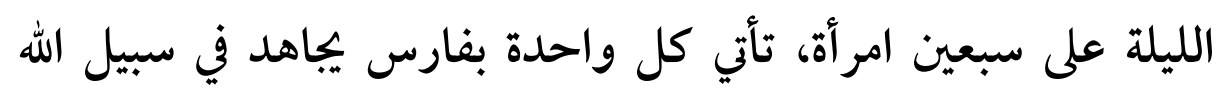

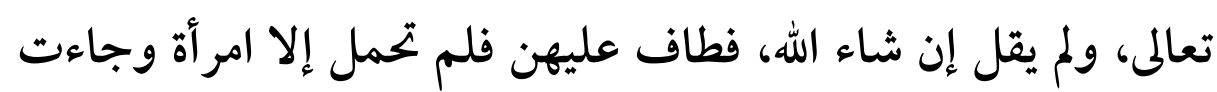

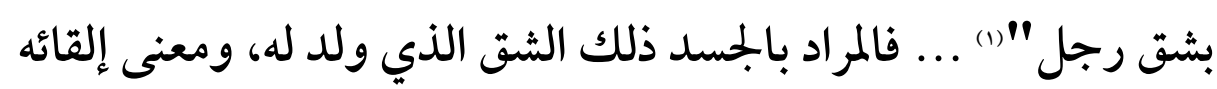
على كرسيه وضع القابلة له عليه ليراه.

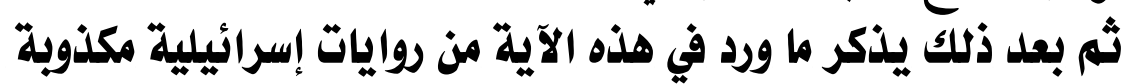

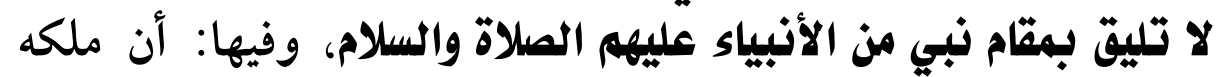

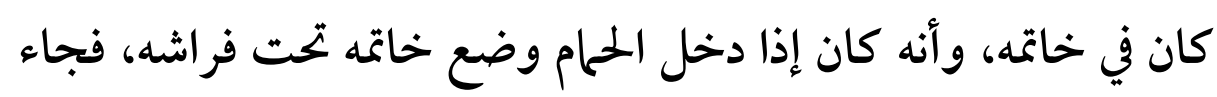

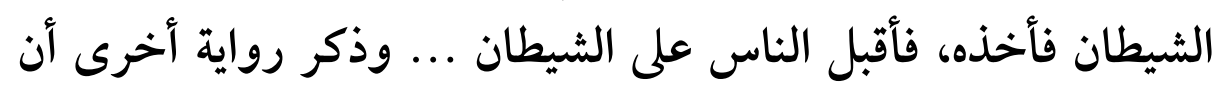

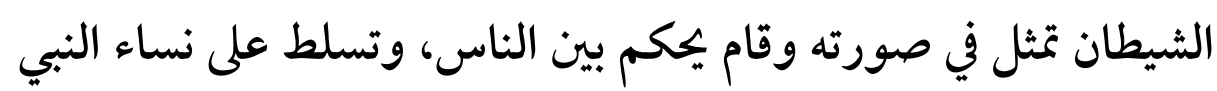
سليمان حتى ووطئهن وهن حيض، إلى أن علم نبي الله سليمان بأمره وكثف حاله، فلما علم الشيطان أن أمره قد انقطع أمر الشياطين فكتبوا كتبًا فيها سحر ومكر فدفنوها تحت كرسي سليان ثم أثاروها وقرؤوها

ورحمة الله، فكل من يدخل الجنة على صورة آدم، فلم يزل الخلق ينقص حتى الآن".

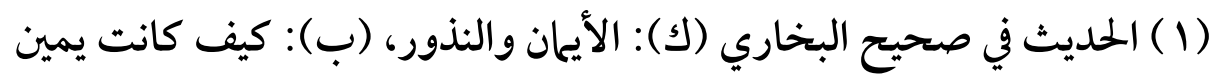

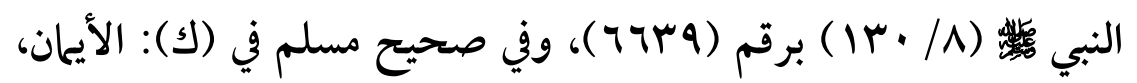

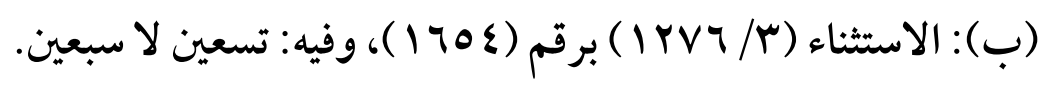


على الناس وقالوا: بهذا كان يظهر سليان على الناس ويغلبهم فأكفر

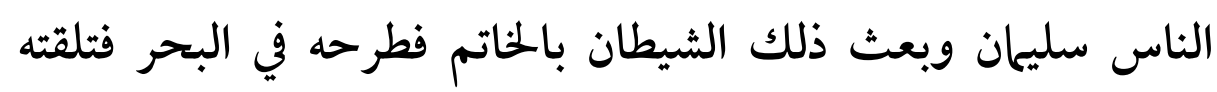

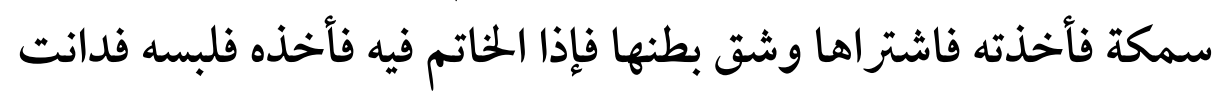

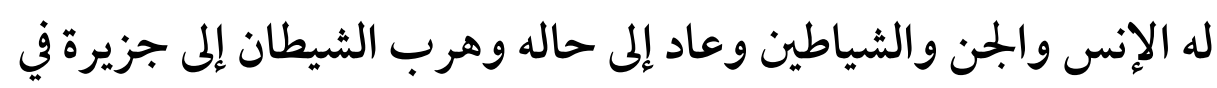

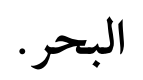

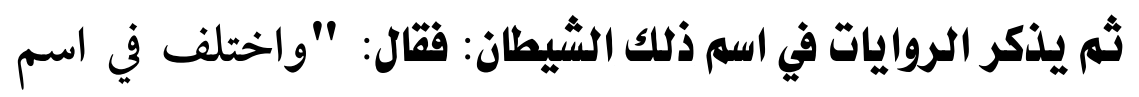

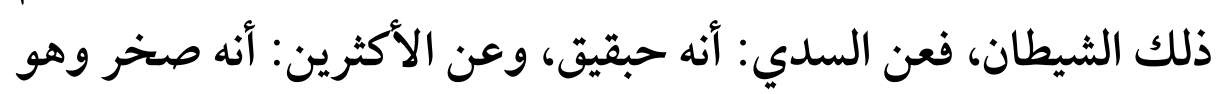

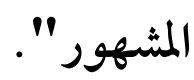

ثم نجده ينقل عن أبي حيان قوله: إن هذه المقالة من أوضاع اليهود

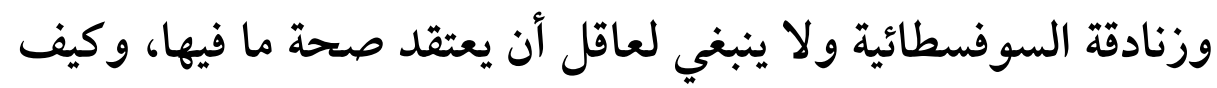

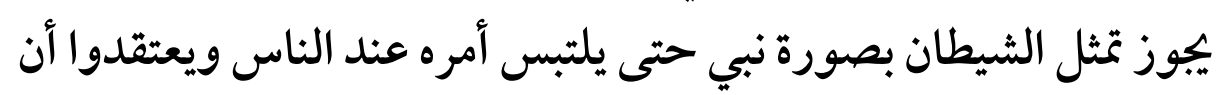

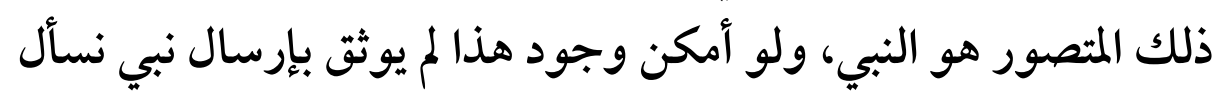

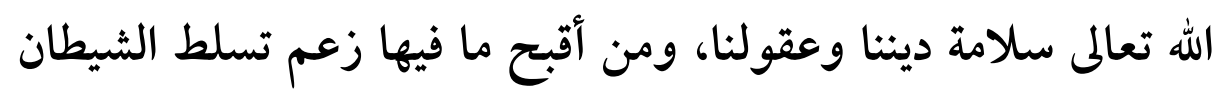

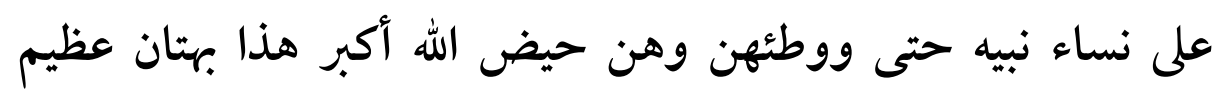

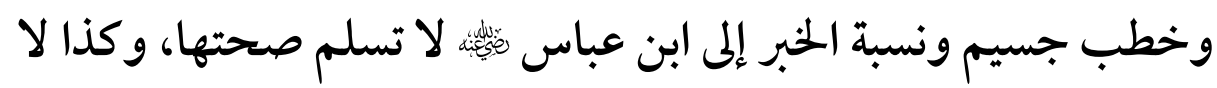

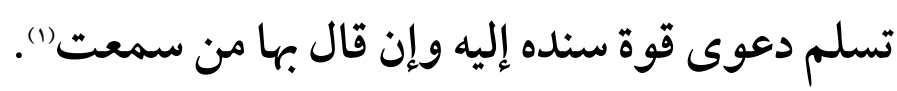

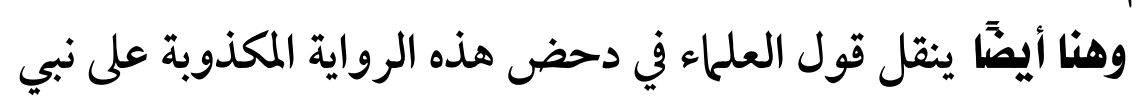

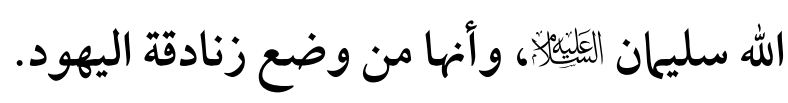
(1) (روح المعاني)(r/191)، وينظر : (البحر المحيط) (19/9). 
رابعاً: الإنكار على من ينقل ما لا يصح

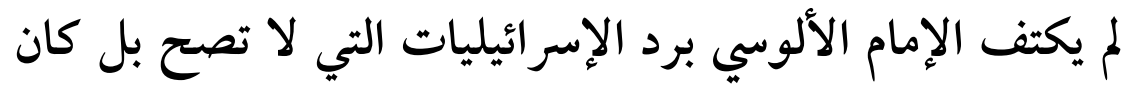

ينكر على من ينقل ما لا يصح منها بدون ردها وبيان زيفها.

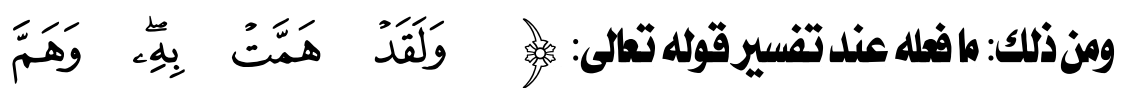

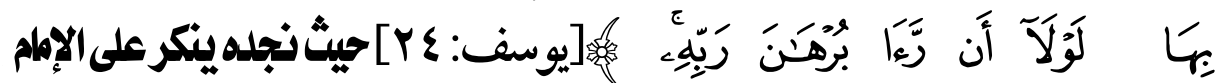

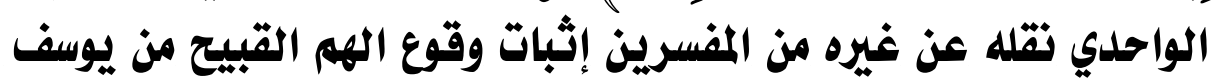

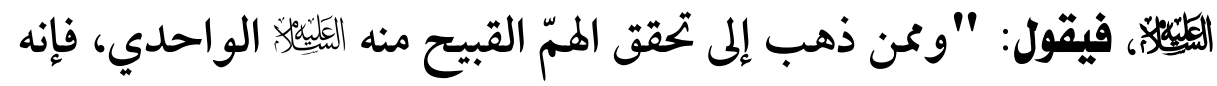
قال في كتاب البسيط: قال المفسرون الموثوق بعلمهم المرجوع إلى الى المي

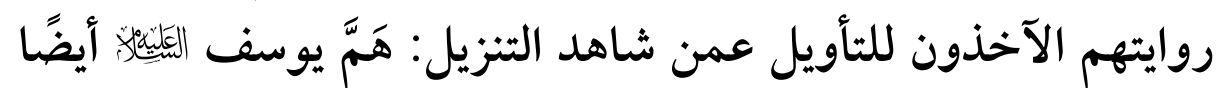

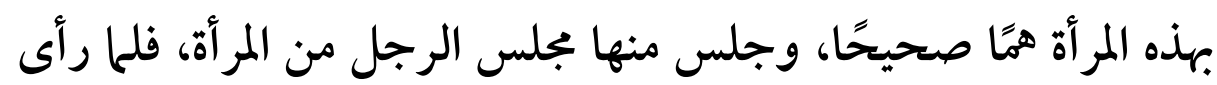
البرهان من ربه زال كل شهوة عنه" (1). ويذكر بعدها عدة روايات في المراد بالبرهان، والتي منها: أنه مُشثّل

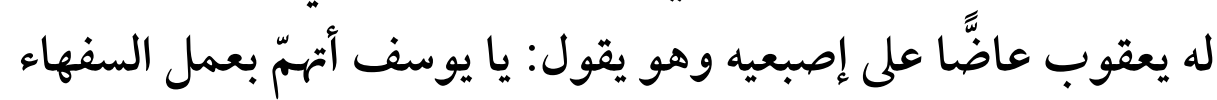
وأنت مكتوب من الأنبياء".

ثم يذكر تعليق الفخر الرازي على هذه المرويات فيقول: "وتعقب الدب

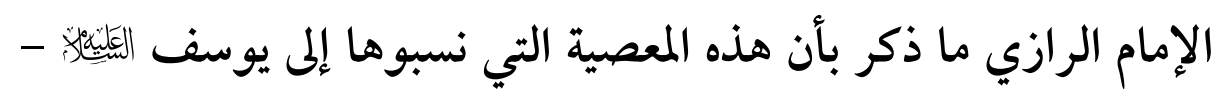

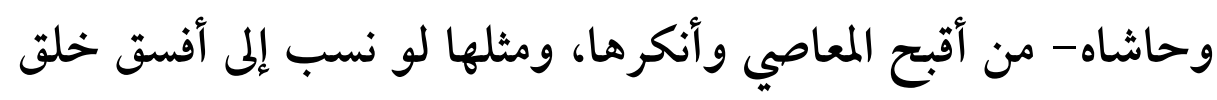

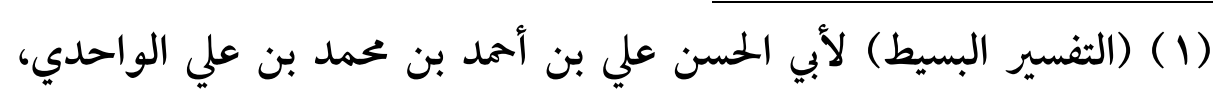

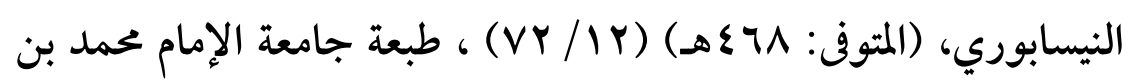

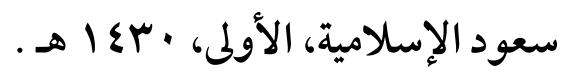


الله تعالى وأبعدهم عن كل خير لاستنكف منه، فكيف يجوز إسناده إلى هذا الصديق الكريم؟ "(1).

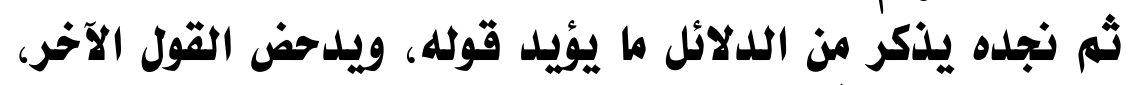

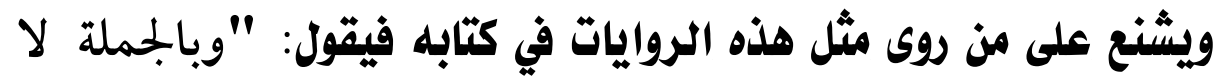

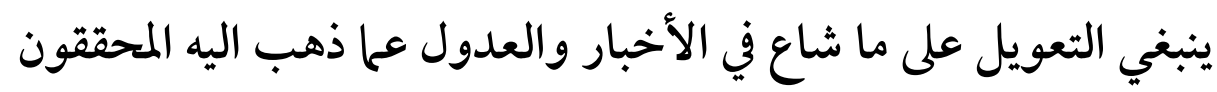

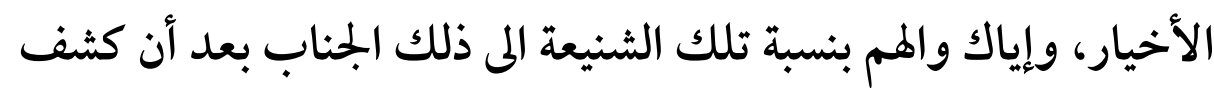
الله سبحانه عن بصر بصيرتك فر أيت برهان ربك بلا حجاب" "(r). خامساً: علم التسليه بصحة المروي ثم تفسير الآية تفسيرًا إشاريًا تأثرًا بنزعته الصوفية

إذا كان الإمام الألوسي يشدد النكير على من شغفوا بالإسرائيليات الموفئ من المفسرين، ويبطل منها مالا يقوم الدليل على صحته، فإنا نراه أحيانا - يسلّم بصحة بعض القصل ويطل منع الإسرائيلي على ظاهره ويجعله من

$$
\text { باب الرمز والإشارة. }
$$

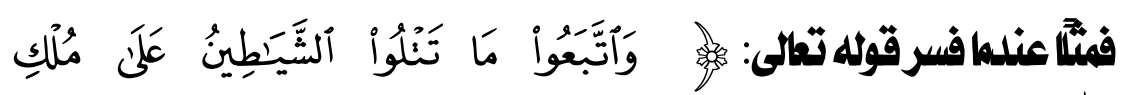

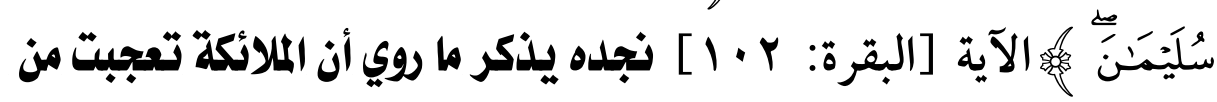

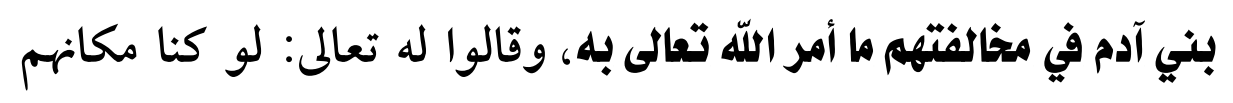

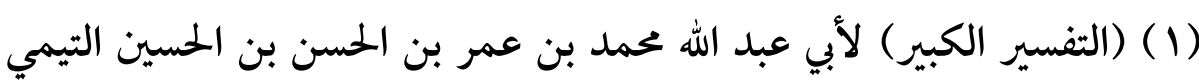

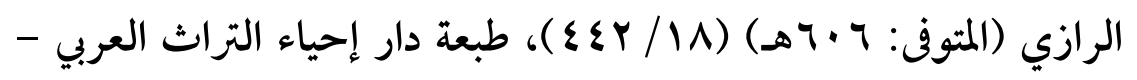

$$
\begin{aligned}
& \text { بيروت . } \\
& \text { (Y) (روح المعاني) (T/ ه • ع ) وما بعدها. }
\end{aligned}
$$


ما عصيناك، فقال: اختاروا ملكين منكم، فاختاروهما، فهبطا إلى الأرض

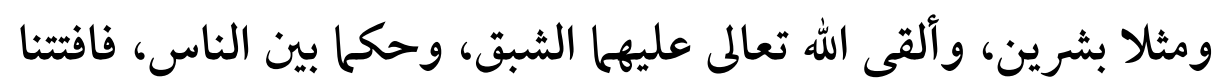

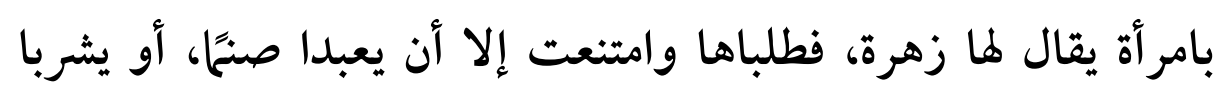

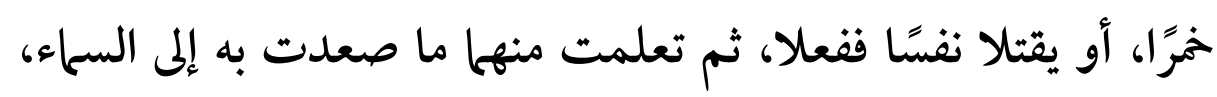

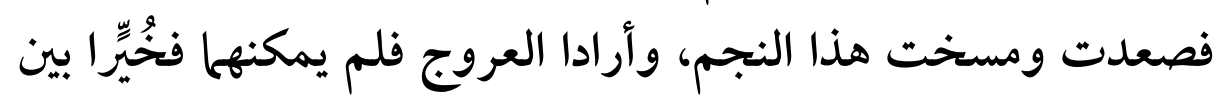

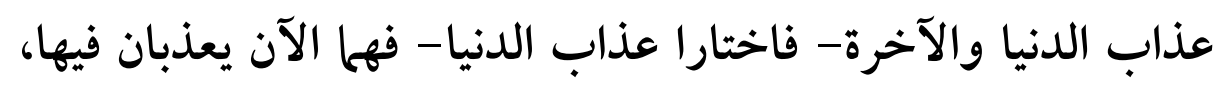
إلى غير ذلك من الآثار التي بلغت طرقها نيفا وعشرين "(1). ثم ينكر هذه القصة، وينقل إنكار من أنكرها من العلماء كالقاضي ولئي

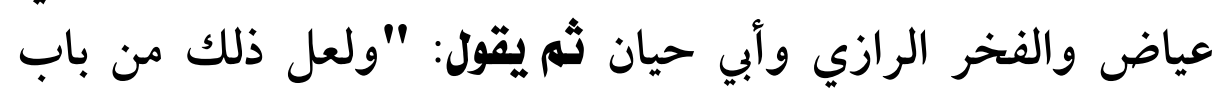

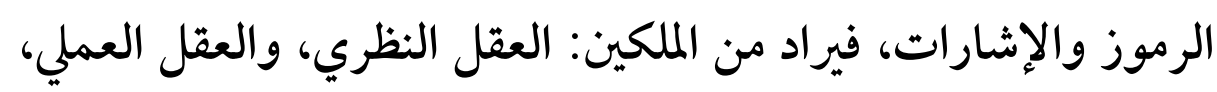

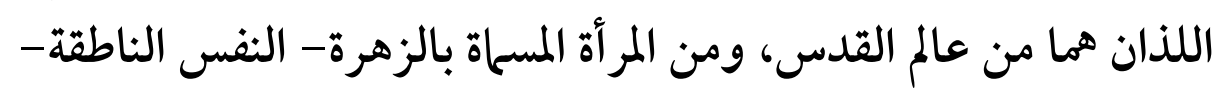
ومن تعرضها لها تعليمها لها ما يسعدها، ومن حملها إياهما على المعاصي تحريضها إياهما بحكم الطبيعة المزاجية إلى الميل إلى السفليات المدنسة فئسة

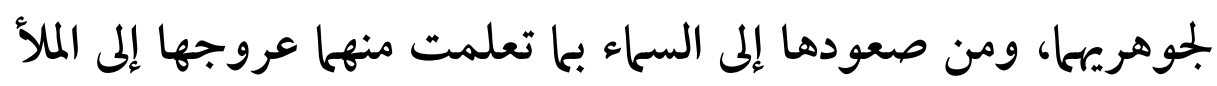
الأعلى وخخالطتها مع القدسيين بسبب انتصاحها لنصحهرا، ومن بقائها

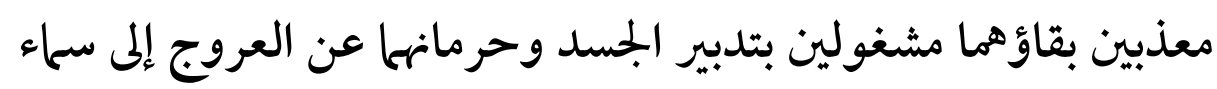

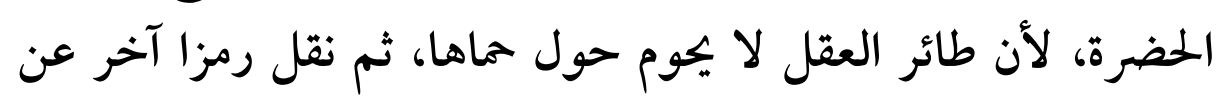

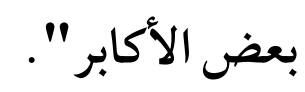

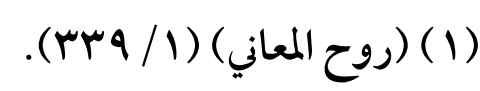


ثم يعود لينكر على من قال بصحة هذه القصة فيقول: "ومن قال

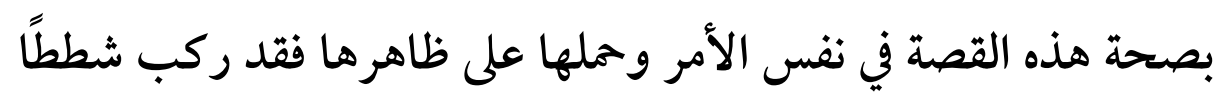
وقال غلطًا، وفتح بابًا من السحر يضحك الفه الموتى، ويبكي الأحياء،

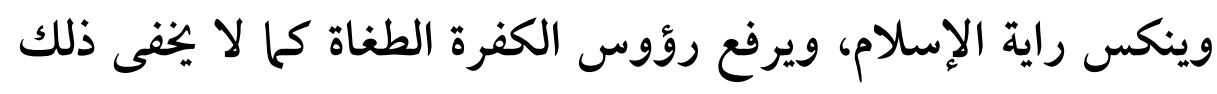
على المنصفين من العلم|ء المحققين "(1). والمجب من الإمام الألوسي أن يجعل هذه المجعين القصة من قبيل المبل الرمز

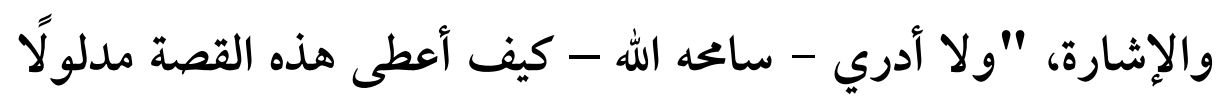

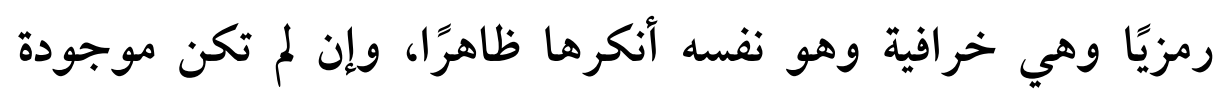

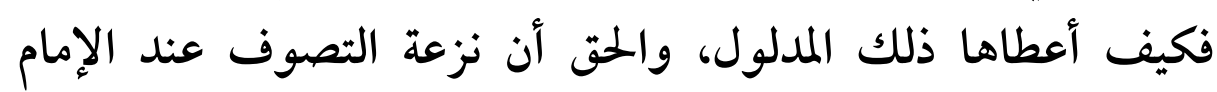
الألوسي أوقعته في مثل هذه الشطحة البعيدة).(1).

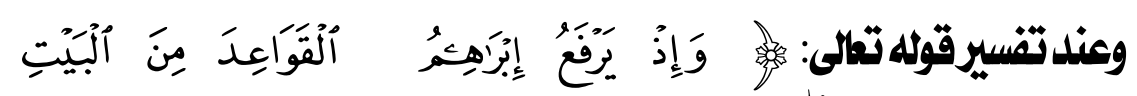

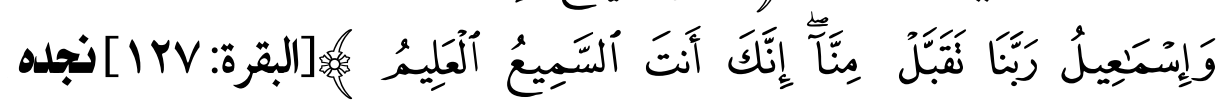

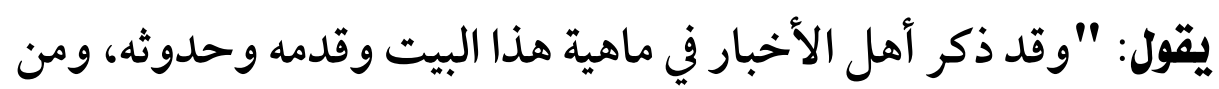
أي شيء كان باباه؟ وكم مرة حجه آدم؟ ومن أي شيء بناه إبراهيم؟

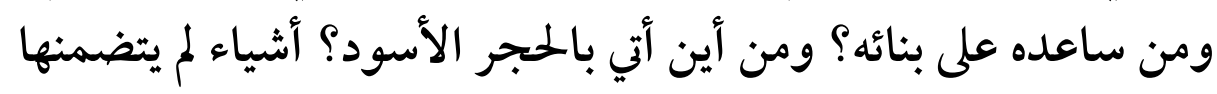

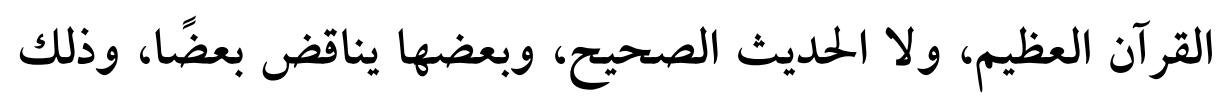

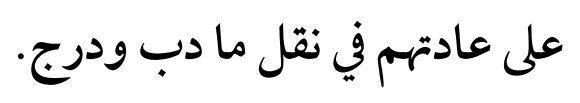

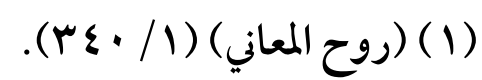

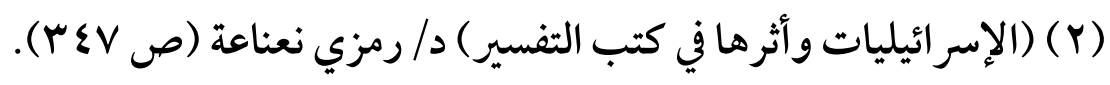


ومن مشهور ذلك: أن الكعبة أنزلت من السماء في زمان آدم، ولما

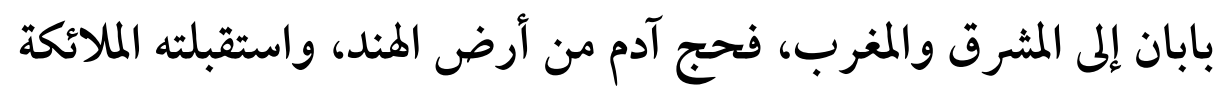

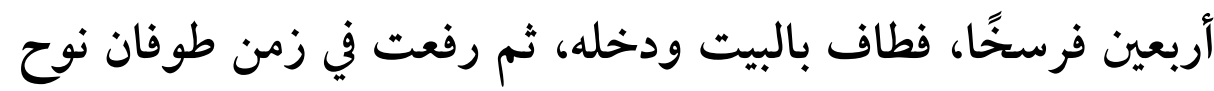

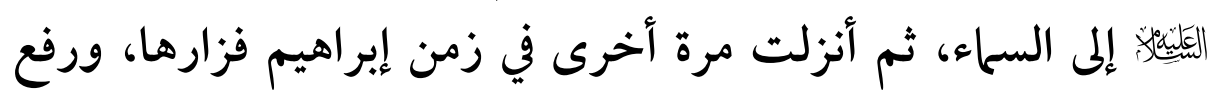

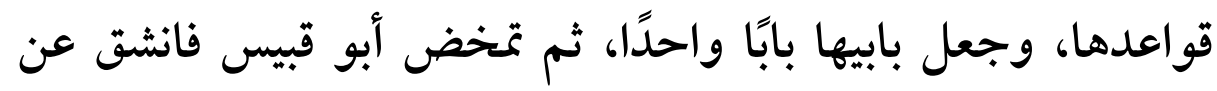

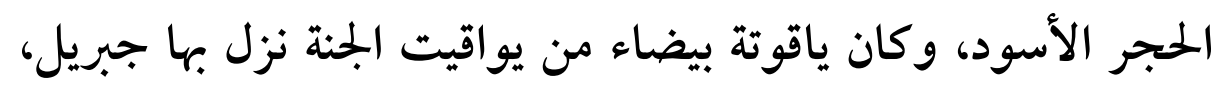

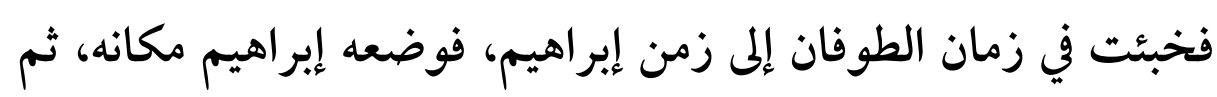

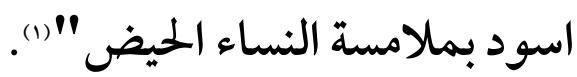

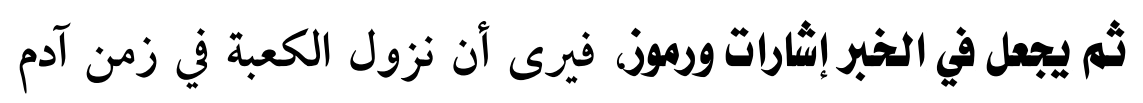

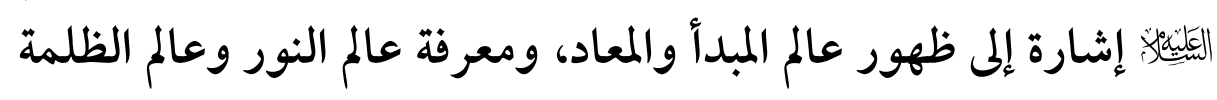

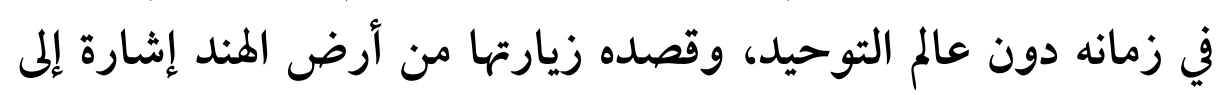

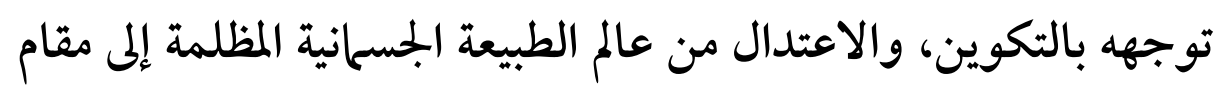
القلب، واستقبال الملائكة إشارة إلى تعلق القوى النباتية والحيوانية

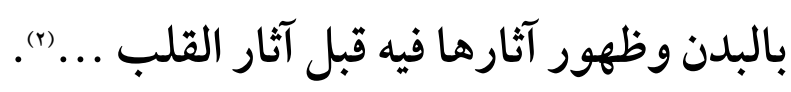

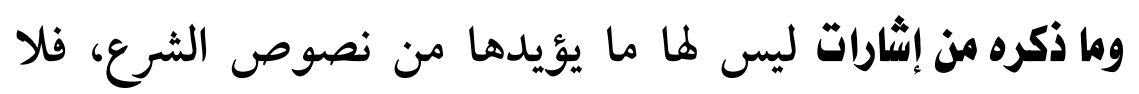

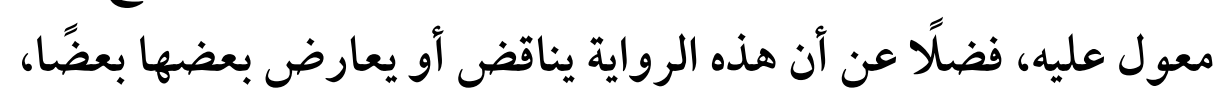

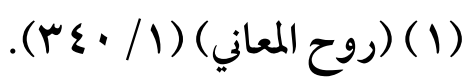

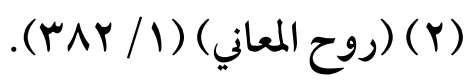


فهي فاسدة في تناقضها وتعارضها، وفاسدة في عدم صحة أسانيدها، وفاسدة في مخالفتها لظاهر القرآن.

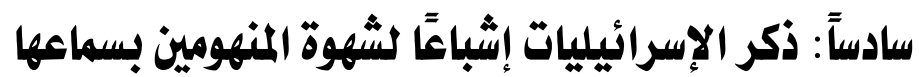

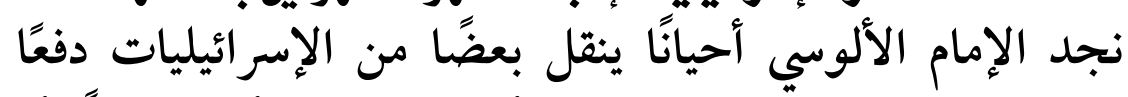

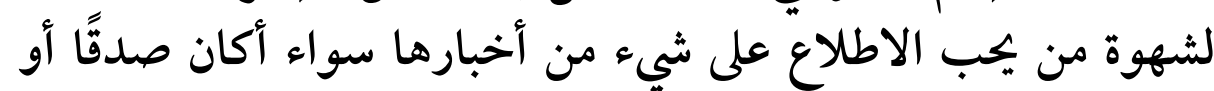
كذبًا.

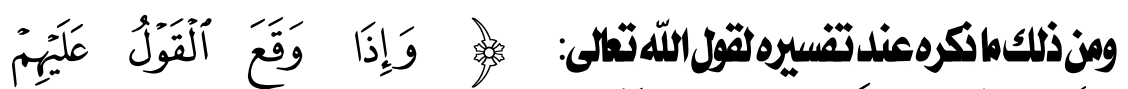

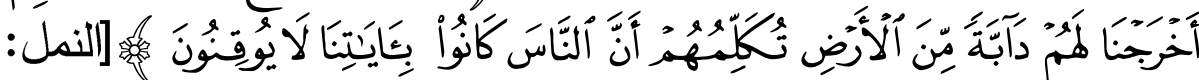

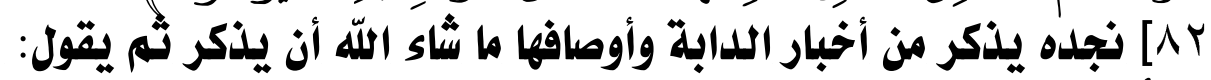
والأخبار في هذه ئو الدابة كثيرة. ثم ينقل قول أبي حيان فيقول: "وفي البحة البحر أنهم اختلفوا في

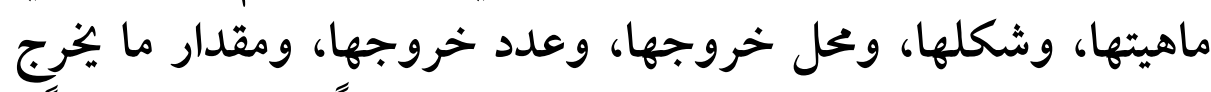

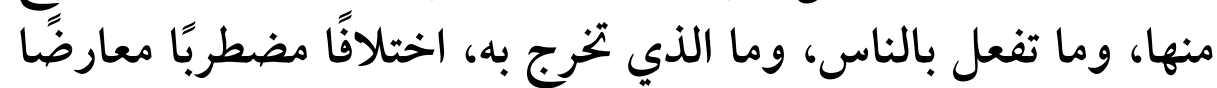

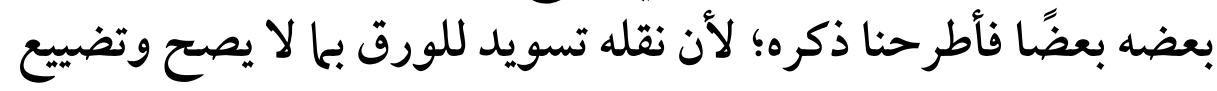
لزمان نقله" (1). ثم يعقب على كلام أبي حيان بقوله: "وهو كلام حق وأنا إنما نقلت بعض ذلك دفعا لشهوة من يجب الاطلاع على شيء من أخبارها صدقًا

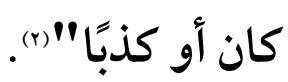

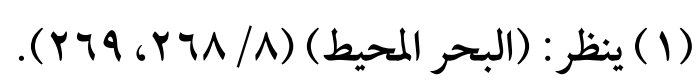

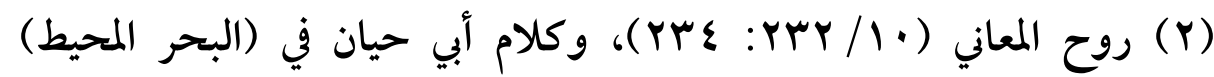

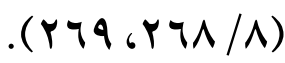




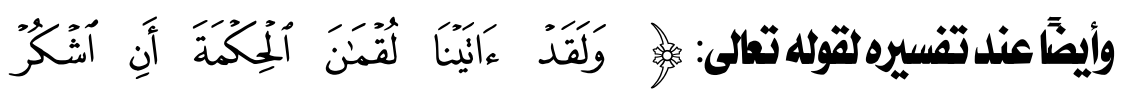

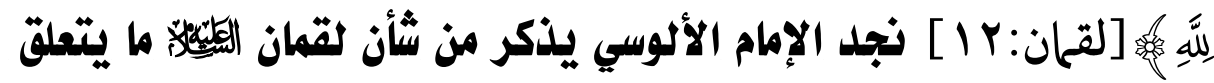

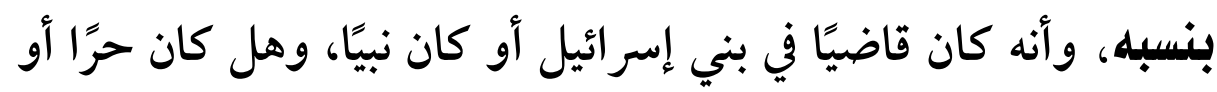

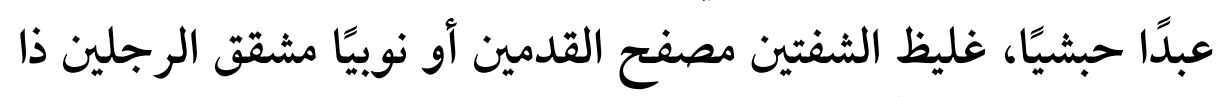

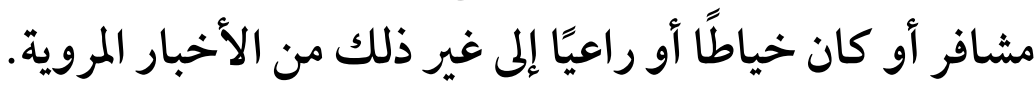

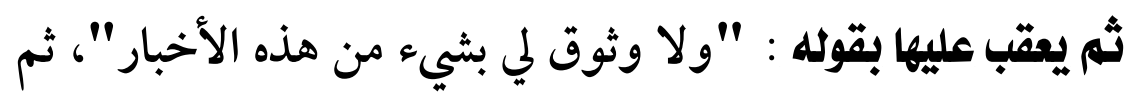

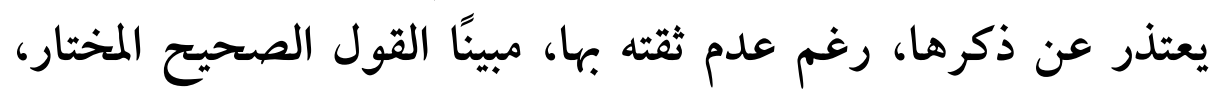

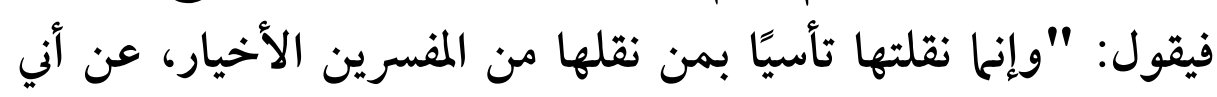

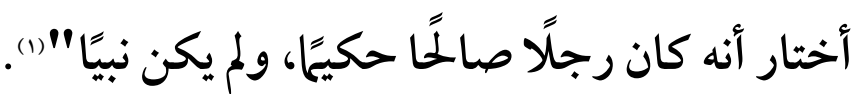

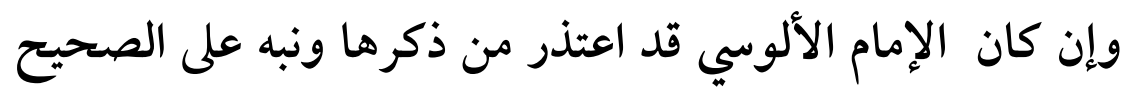
منها، لكن كان الأولى أن يكتفي بالإنشارة إليها لا نقلها.

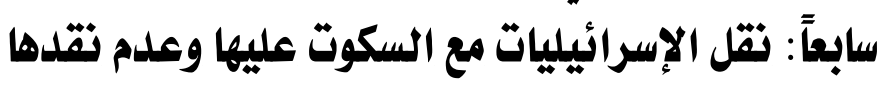

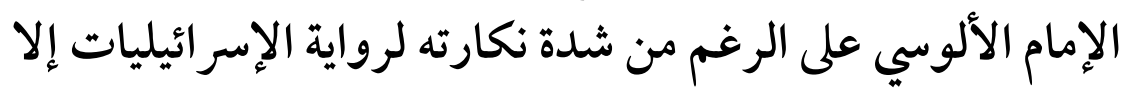

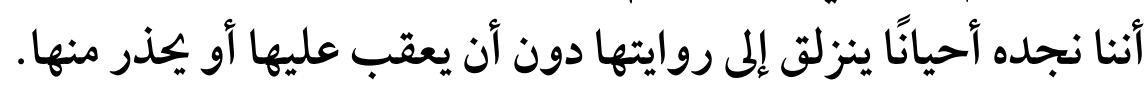

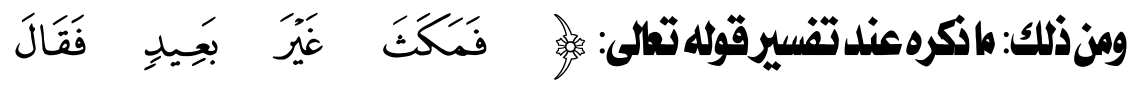

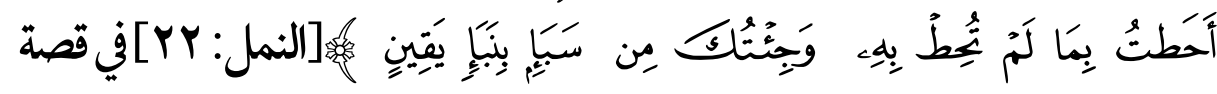

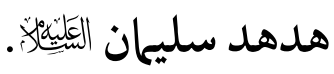

(1) (روح المعاني) (11/1). 
( $\vee \& \varepsilon)$

الإمام الألوسي وجهوده في نقد الإسرائيليات من خلال تفسيره روح المعاني

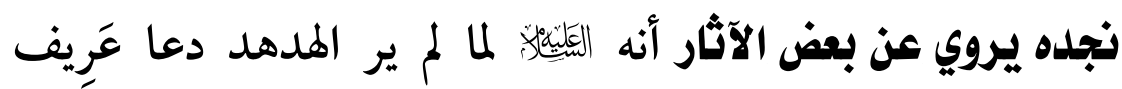

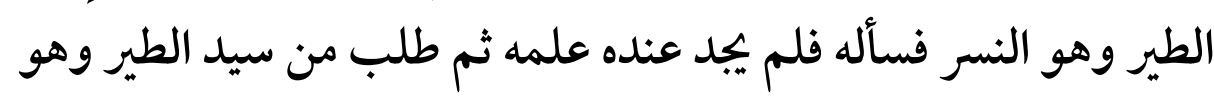

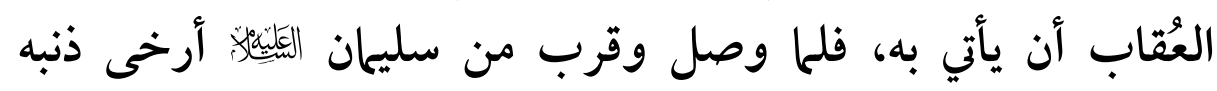

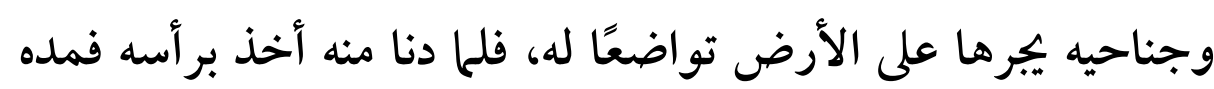

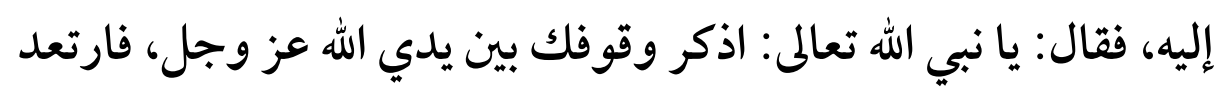
سليان وعفا عنه، وعن عكرمة: أنه إنلا عفا عنه؛ لأنه كان بان بارًا بأبوريه

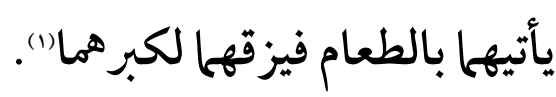
وهذه القصة تحمل الكثير من التساؤلات فمن الذي نقل فئل لنا لنا حوار

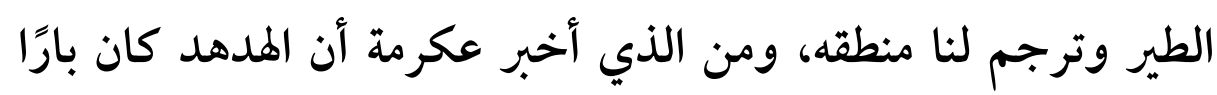

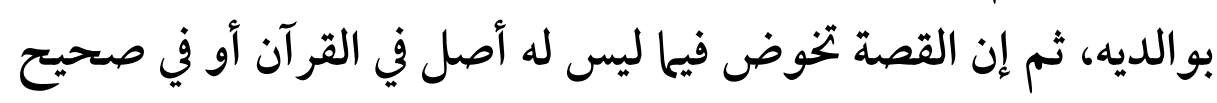
السنة، ومع ذلك ينقلها بلا تعقيب ولا تفنيد لما فيها. 


\section{الخاتمة}

الحمد لله، والصلاة والسلام على سيدنا رسول الله، وعلى آله وصحبه ومن والاه، وبعد:

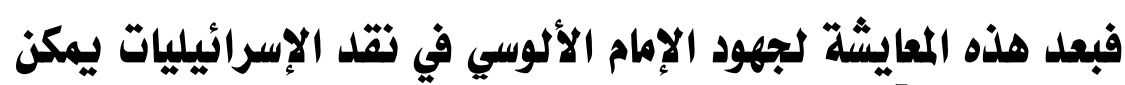
لنا أن نستخلص بعضًا من النتائج، التي منها:

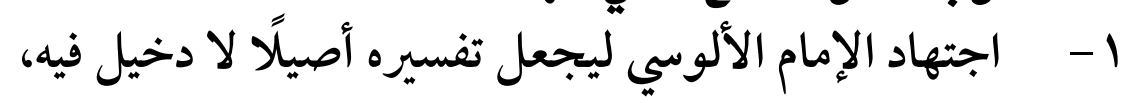
لكن الكمال لله، والعصمة لأنبيائه.

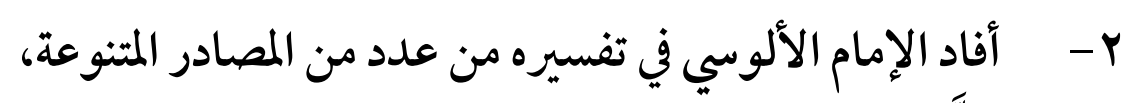

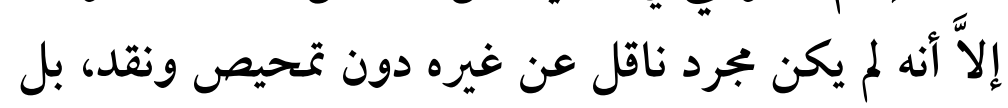
كان له تعقبات واختيارات واستنباطات تدل على تمكنه عنده دونه ورسوخه العلمي؛ وهذا ما جعل كتابه أحد المراجع المهمة تعلئ في علم التفسير. r- وقف الإمام الألوسي موقف التفسير الرفض للإسر ائيليات، والنقد

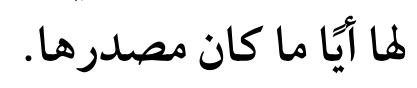
ع - شدة استنكار الإمام الألوسي للمرويات الإسرائيلية التي تتعلق بجانب العقيدة أو تتنافى مع عصمة الأبياء.

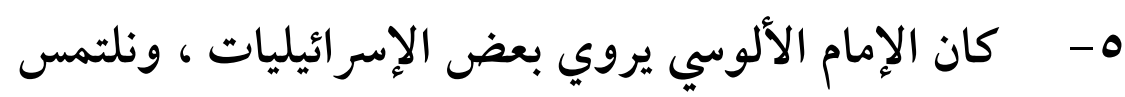

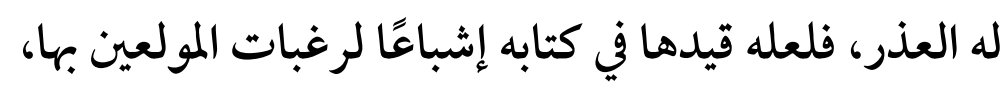
أو تأثر ا بالنزعة الصوفية والرمز. 
( الإمام الألوسي وجهوده في نقد الإسرائيليات من خلال تفسيره روح المعاني

$$
\begin{aligned}
& \text { צ- تميز الإمام الألوسي بعددٍ من السِمات التي كان لها دورها } \\
& \text { المؤثر في تكوين شخصيته الناقدة. }
\end{aligned}
$$

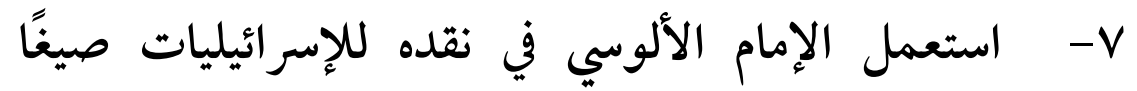

$$
\text { متعددة في تفسيره. }
$$

\section{أما عز أهم التوصيات قتتمثل في الآتي:}

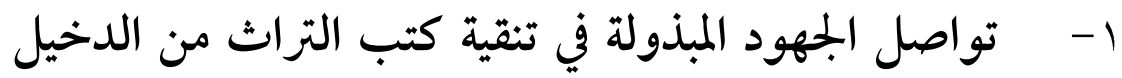

لوقف السيل الجارف من ترهات المستشرقين وأذنابهم من يهدفون إلى نشر الأفكار المغلوطة والتي تؤدي إلى زعزب ترهي

$$
\text { الأمن والاستقرار في المجتمع. }
$$

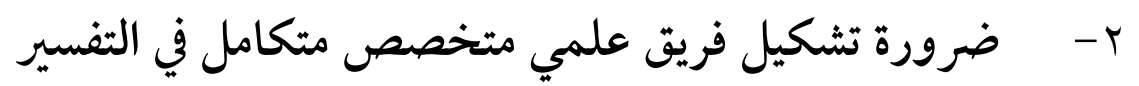
والحديث واللغة، مهمته البحث في كتب التراث التفسيري وتمحيصه وغربلته مما لا يليق وجوده بجروار كلام الله تعالم.

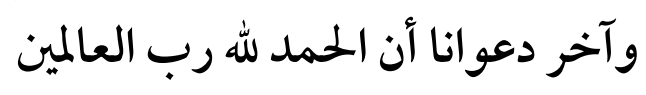




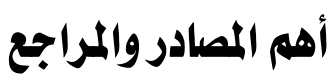

أولاً: كتب التفسير وعلوم القرآن

1 - الإتقان في علوم القر آن للإمام جلال الدمان الدين السيوطي تحقيق

محمد أبو الفضل إبراهيم، طبعة الهيئة المصرية العامة

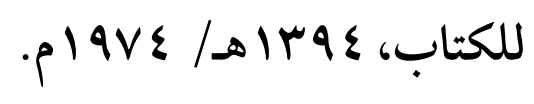

Y - الإسرائيليات في التفسير والحديث للدكتور محمد حسين

الذهبي، طبعة مكتبة وهبة بالقاهرة، بدون سنة الطبع.

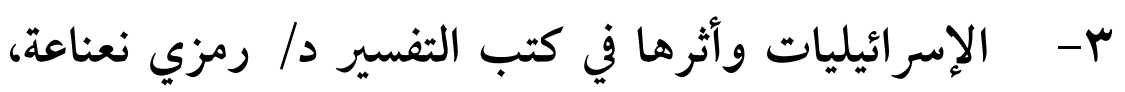

نشر وتوزيع دار القلم بدمشق، ودار الضياء بيروت، الإني

$$
\text { الأولى · · }
$$

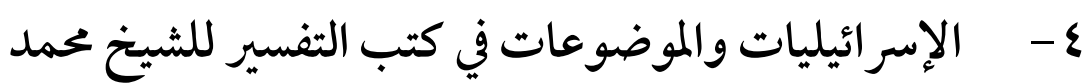

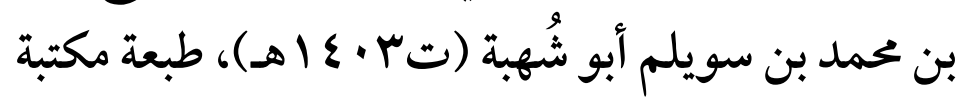

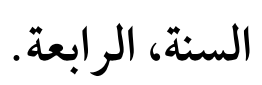

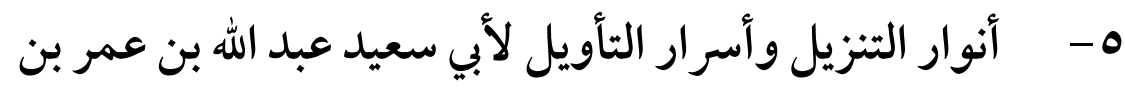

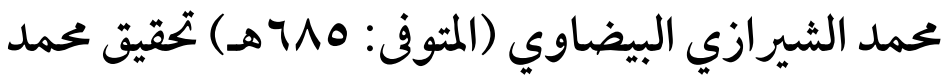

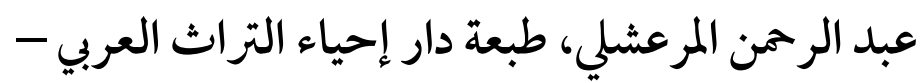

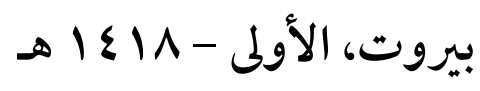

T- البحر المحيط في التفسير لأبي حيان محمد بن يوسف بن بن علي

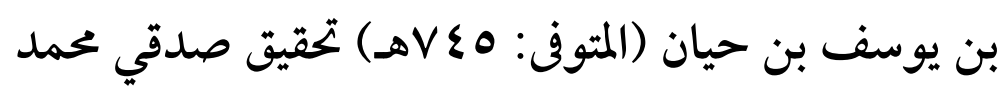

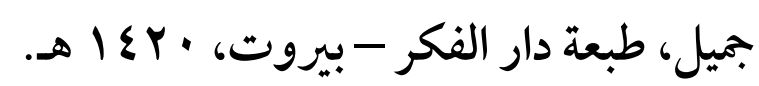


التفسير البسيط لأبي الحسن علي بن أحمد بن محمد بن علي -V

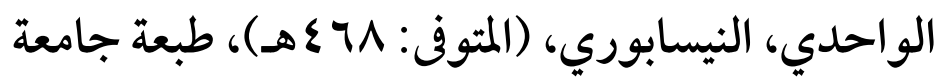

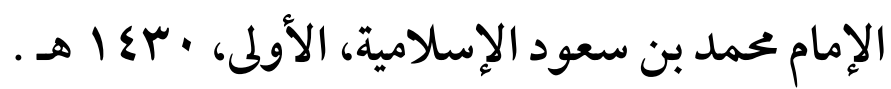

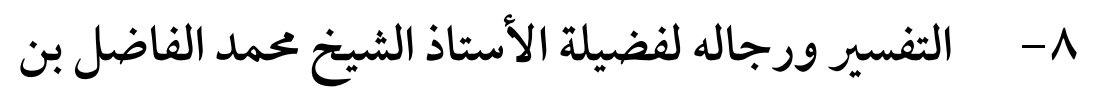

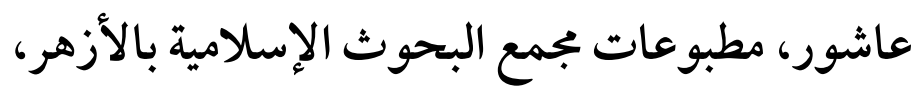

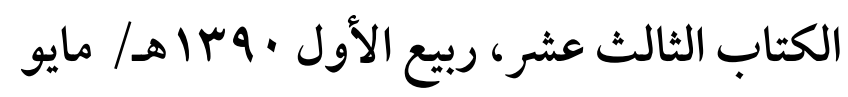
. $19 \mathrm{~V}$. 9- تفسير القرآن العظيم لأبي الفداء إسماعيل بن عمر بن كثير

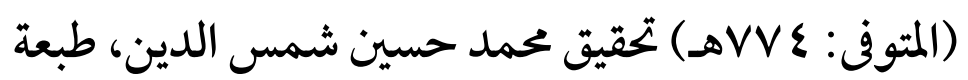

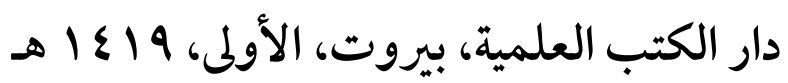

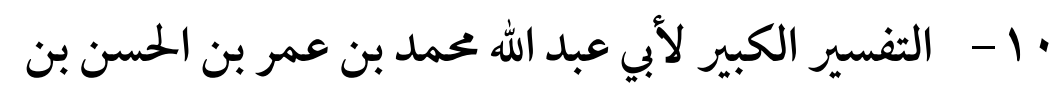

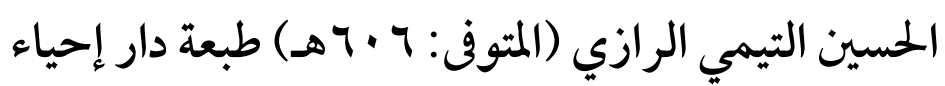

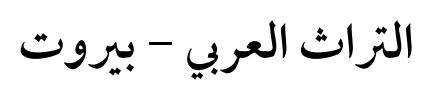
11- التفسير والمفسرون للدكتور محمد حسين الذهبي

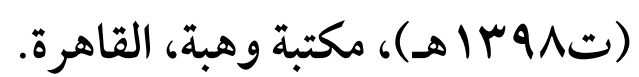
r ا - روح المعاني في تفسير القرآن العظيم والسبع المثاني للإمام شهاب الدين محمود بن عبد الله الحسيني الإمام الألوسي

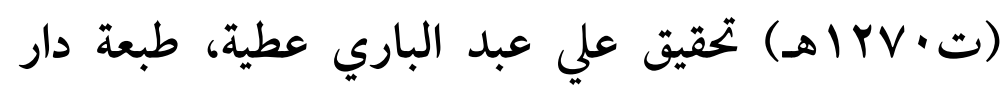

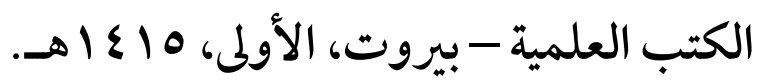


rا - الكشاف عن حقائق غوامض التنزيل لأبي القاسم محمود

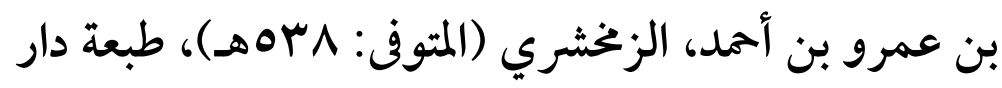

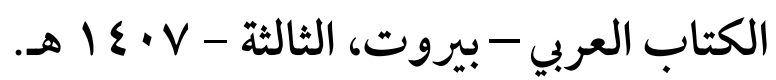
ع ا - مقدمة في أصول التفسير لتقي الدين أبو العباس أحمد بن

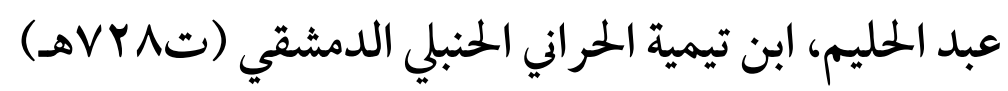

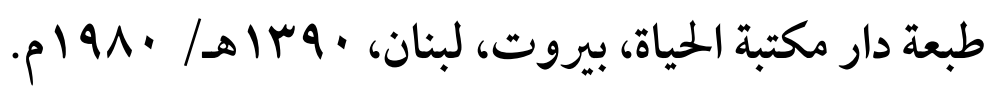

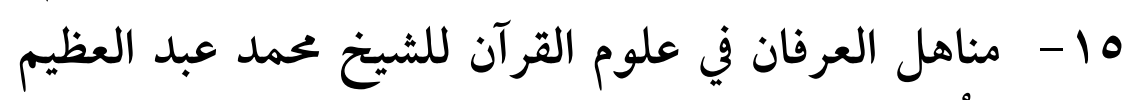

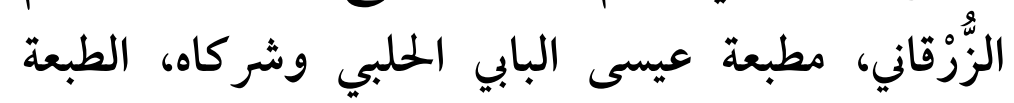
الثالثة.

\section{ثانياً: كتب الحديث الشريف وعلومه}

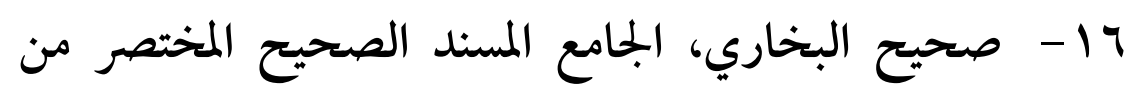

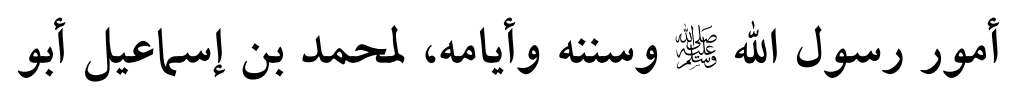

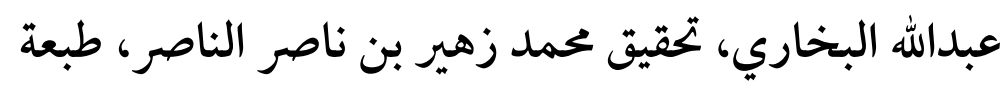

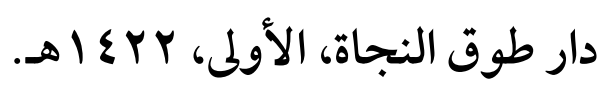

- IV

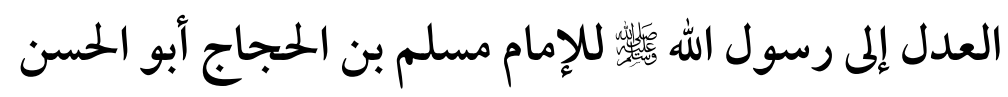

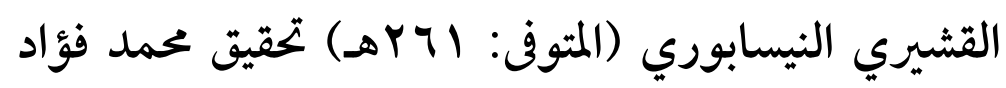
عبد الباقي، طبعة دار إحياء التراث العربي - بيروت. النئ. 


\section{ثالثًا: كتب اللفة والأدب والمعاجم الأبم}

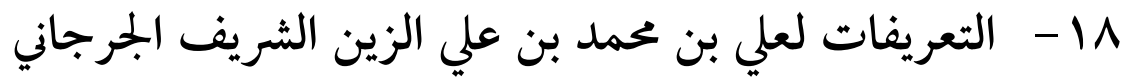

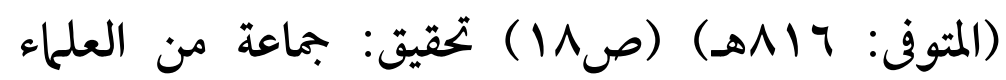
بإشراف الناشر، دار الكتب العلمية بيروت -لبنان، الأولى العيل

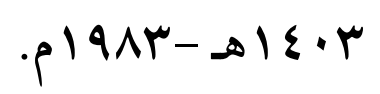

19 - لسان العرب لمحمد بن مكرم بن على، أبو الفضل، جمال الدين ابن منظور الأنصاري الرويفعى الإفريقى (المتوفى:

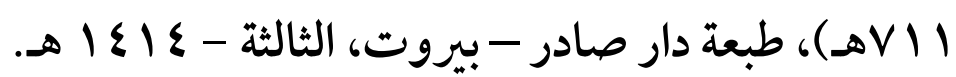

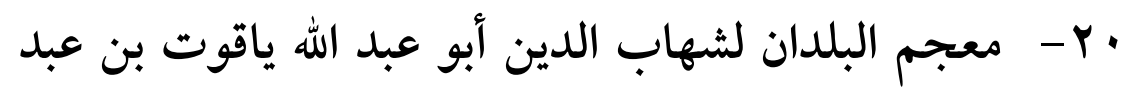

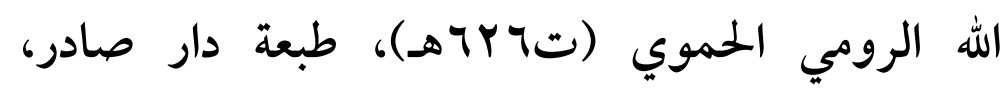
بيروت، الثانية، 1990 م م. ا - - معجم ما استعجم من أسماء البلاد والمواضع لأبي عبيد عبد البانية

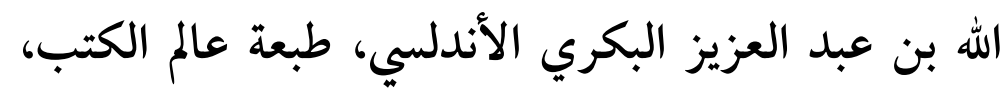

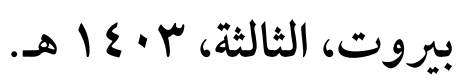

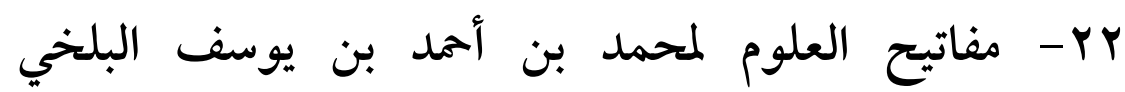

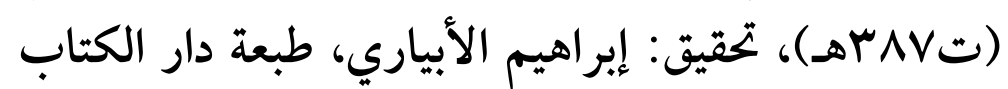
العربي، الثانية.

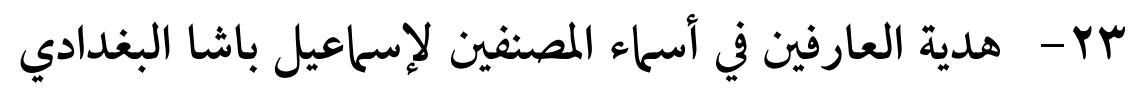
طبعة إحياء التراث العربي بيروت، بدون رقم الطبعة وتاريخها. 


\section{رابعاً: كتب التاريخ والبلدان:}

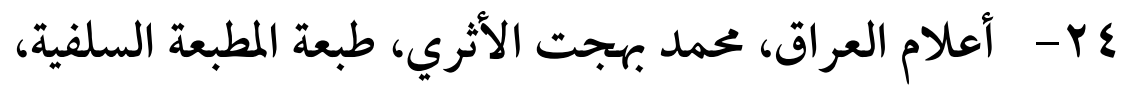
.

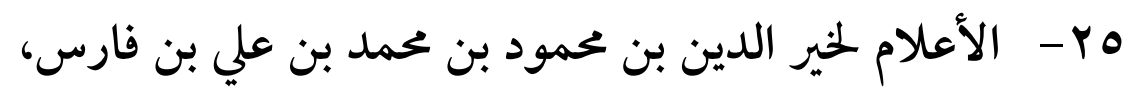

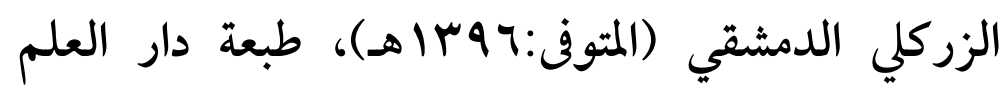

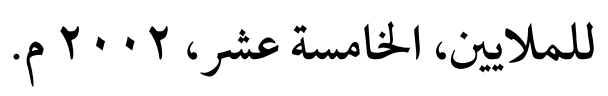

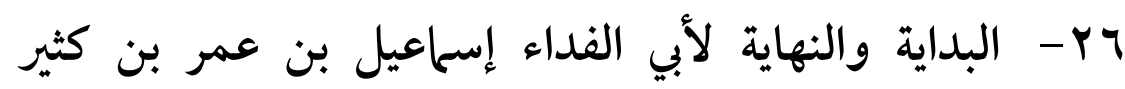

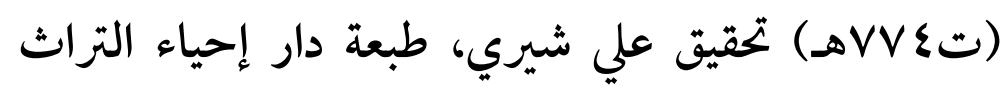

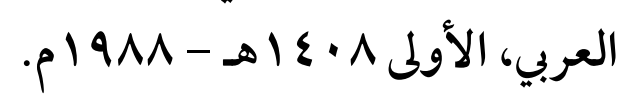

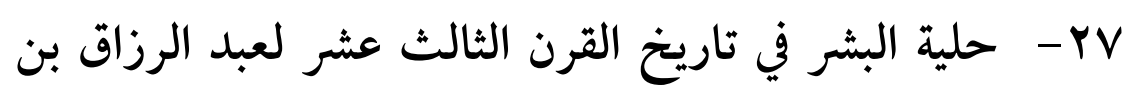

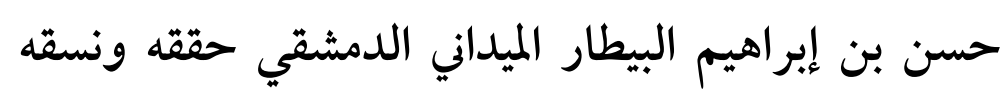

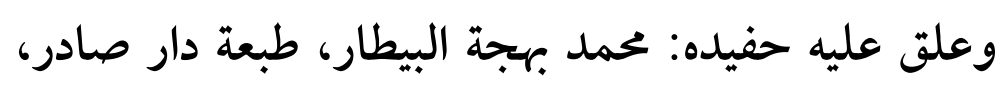

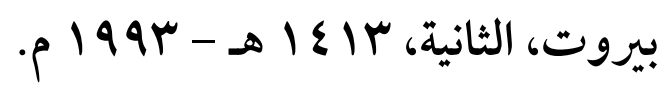

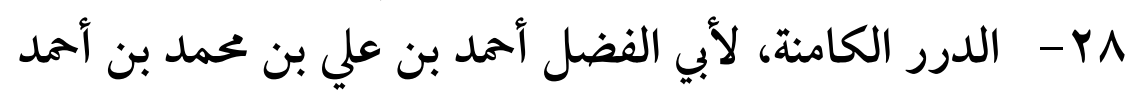
بن حجر العسقلاني (ت مبهـه)، تحقيق محمد عبد المعيد

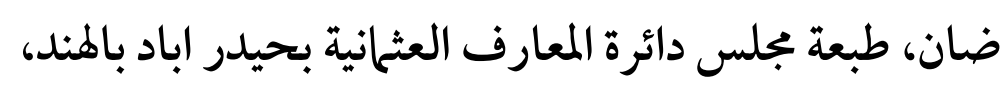

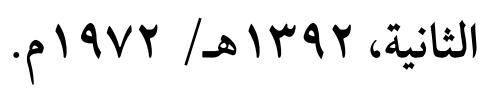

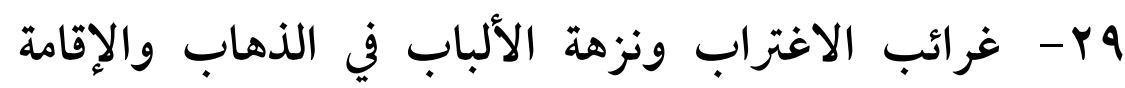
والإياب لشهاب الدين محمود بن عبد الله الحسيني الإمام 


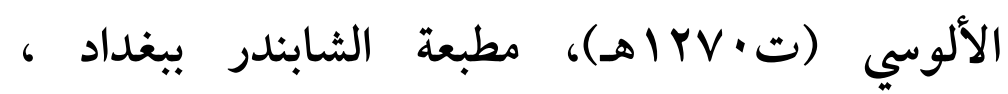

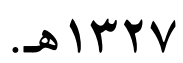

\section{خامساً: كتب التراجم والطبقات}

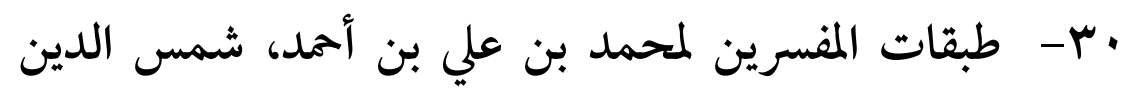

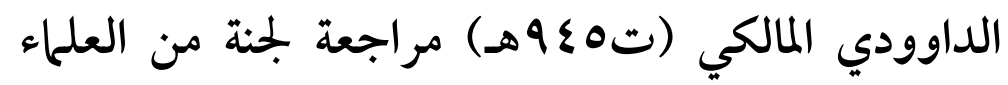

$$
\text { بإشر اف الناشر، طبعة دار الكتب العلمية. }
$$

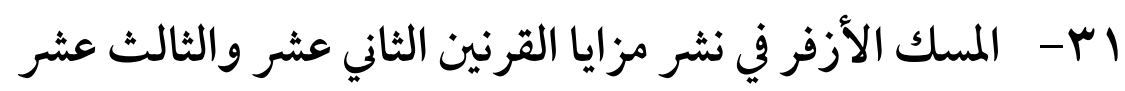

للسيد محمود شكري الإمام الألوسي، تحقيق د/ المبد عبد الله

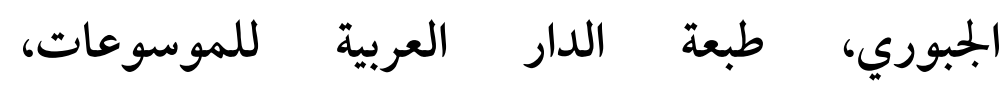

$$
\text { الأولى، الحيوري، }
$$

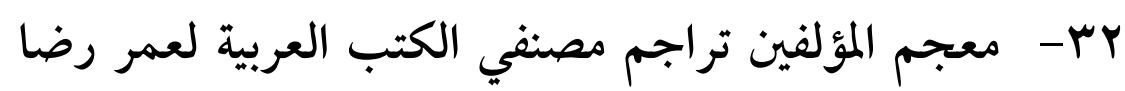

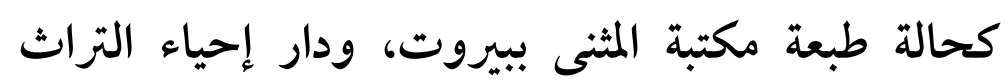

$$
\text { سادساً: مصادر أخرى العربي. }
$$

r ب- محاضرات في مناهج البحث والمكتبة الإسلامية، إعداد

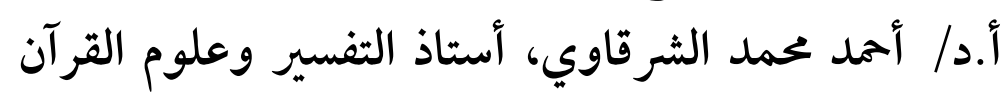

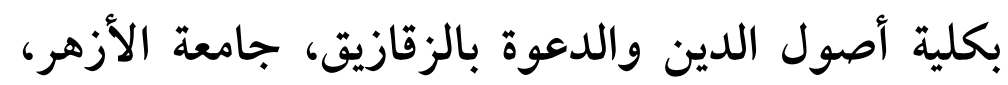

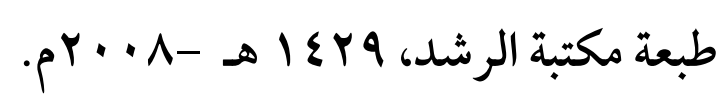

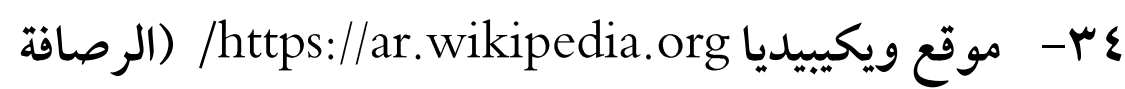

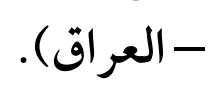


فهرس المحتويات

\begin{tabular}{|c|c|c|}
\hline الصفحة & 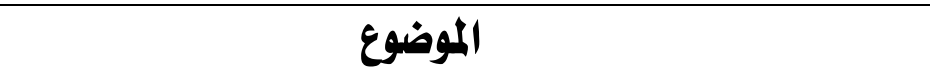 & $\hat{r}$ \\
\hline$r \cdot r$ & ملخص البحثُ باللغة العربية & 1 \\
\hline r.\& & ملخص البحثُ باللغة الإنجليزية & $r$ \\
\hline r.o & مقدمة & $r$ \\
\hline YII & المبحثُ الأول: الإمام الألوسي وتفسيره روح المعاني & $\xi$ \\
\hline YII & المطلب الأول: ترجمة مختصرة للإمام الألوسي & 0 \\
\hline YYZ & ومنهجله فيه الثاني: تعريف موجز بكتابه: روح المعاني، & 9 \\
\hline rrA & منها، وطريقته في الثاني: الإسرائيليات، وموقف الإمام الألوسي & 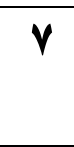 \\
\hline rrA & المطلب الأول: الإسرائيليات، وموقف الإمام الألوسي منها & $\Lambda$ \\
\hline PrI & الألمسلبي الثاني: أقسام الإسرائيليات في تفسير الإمام & 9 \\
\hline Y\&. & الإسرائيليات الثاثث: طريقة الإمام الألوسي في نقل & $1 \cdot$ \\
\hline roo & الخاتمة وتتضمن أبرز النتائج والتوصيات & 11 \\
\hline rov & مراجع البحث & ir \\
\hline rqr & فهرس المحتويات & it \\
\hline
\end{tabular}

